\title{
Palynological studies of the boundary marls unit (Albian-Cenomanian) from northeastern Spain. Paleophytogeographical implications
}

\author{
UXUe VILLANUEVA-AMADOZ \\ Departamento de Paleontología, Instituto de Geología, UNAM, \\ Ciudad Universitaria, Coyoacan 04510 México D.F. (Mexico) \\ uxuevillanueva@yahoo.es \\ Luis Miguel SENDER \\ Departamento Ciencias de la Tierra (Paleontología), \\ Universidad de Zaragoza, C/Pedro Cerbuna, 12, \\ SP-50009 Zaragoza (Spain) \\ Imsender@unizar.es \\ José Bienvenido DIEZ \\ Departamento Geociencias Marinas y Ordenación del Territorio, \\ Universidad de Vigo, Campus Lagoas-Marcosende, \\ SP-36200 Vigo (Pontevedra) (Spain) \\ jbdiez@uvigo.es \\ Javier FERRER \\ Departamento Ciencias de la Tierra (Paleontología), \\ Universidad de Zaragoza C/Pedro Cerbuna, 12, \\ SP-50009 Zaragoza (Spain) \\ joferrer@unizar.es \\ Denise PONS \\ Université Pierre et Marie Curie, UMR 7207, \\ Centre de Recherche en Paléobiodiversité et Paléoenvironnements (CR2P), \\ Muséum national d'Histoire naturelle, \\ case postale 48, 57 rue Cuvier, F-75231 Paris cedex 05 (France) \\ dpons@snv.jussieu.fr
}

\footnotetext{
Villanueva-Amadoz U., Sender L. M., Diez J. B., Ferrer J. \& Pons D. 2011. - Palynological studies of the boundary marls unit (Albian-Cenomanian) from northeastern Spain. Paleophytogeographical implications. Geodiversitas 33 (1): 137-176. DOI: 10.5252/g2011n1a7.

\begin{abstract}
Detailed records of spore-pollen assemblages from four sites located in the Aliaga and Oliete Sub-basins provide new insights into the palaeoclimatic and palaeogeographic settings during the Albian-Cenomanian transition in the Maestrazgo Basin (northeastern Spain). Palynological taxa such as Afropollis jardinus Doyle, Jardiné \& Doerenkamp, 1982, Elaterosporites klaszii
\end{abstract}


KEY WORDS

Palynology,

Lower Cretaceous,

Albian-Cenomanian

boundary,

paleophytogeography.

MOTS CLÉS

Palynologie,

Crétacé inférieur,

limite Albien-

Cénomanien,

paléophytogéographie.
(Jardiné \& Magloire) Jardiné, 1967, Equisetosporites ambiguus (Hedlund 1966) Singh, 1983, Gabonisporis pseudoreticulatus Boltenhagen, 1967, Senectotetradites varireticulatus Dettmann, 1973, Stellatopollis barghoornii Doyle, 1975, and the dinoflagellate cyst Cyclonephelium chabaca Below, 1981 indicate a latest Albian age for this unit. Abundance of Gondwanan elements such as Afropollis Doyle, Jardiné \& Doerenkamp, 1982, Elaterosporites Jardiné, 1967 and Stellatopollis Doyle, 1975 indicates a northward extension of the paleogeographic distributions of those taxa during this time. Comparison between the studied microflora of the Iberian Range and microfloras from Tethyan and Gondwanan realms allows better understanding of the Tethyan paleogeographic setting.

\section{RÉSUMÉ}

Études palynologiques de l'Unité Marnes de Transition (Albien-Cénomanien) du Nord-Est de l'Espagne. Implications paléophytogéographiques.

Les enregistrements détaillés d'assemblages palynologiques, obtenus à partir de quatre gisements situés dans les sous-bassins d'Aliaga et d'Oliete, fournissent des données nouvelles sur les paramètres paléoclimatiques et paléogéographiques à la transition Albien-Cénomanien dans le bassin du Maestrazgo (nord-est de l'Espagne). Certains taxons tels que Afropollis jardinus Doyle, Jardiné \& Doerenkamp, 1982, Elaterosporites klaszii (Jardiné \& Magloire) Jardiné, 1967, Equisetosporites ambiguus (Hedlund 1966) Singh, 1983, Gabonisporis pseudoreticulatus Boltenhagen, 1967, Senectotetradites varireticulatus Dettmann, 1973, Stellatopollis barghoornii Doyle, 1975 et le dinoflagellé Cyclonephelium chabaca Below, 1981 permettent de proposer un âge Albien terminal aux «Marnes de transition ». La présence et l'abondance des éléments gondwaniens, observés dans les assemblages indiquent l'extension vers le nord de leurs aires de répartition pendant cette période. Une comparaison entre la microflore étudiée et celles des domaines téthysien et gondwanien permet une meilleure compréhension du cadre paléogéographique.

\section{INTRODUCTION}

In the late Albian pulses of relative sea-level rise are known reaching a maximum eustatic level seen in the early Turonian (Haq et al. 1988). At the base of the sedimentary succession and to the northeast of the Bajo Aragón (northeastern Spain) detrital material of coastal river environments represented by the Utrillas Formation was deposited, followed by shallow carbonate platform environments with subtidal bars that recorded a shallowing-upward trend. During the latest Albian-early Cenomanian transition a drop in sea level occurred that favoured the deposition of marls restricted to coastal environ- ments, represented by the so-called Boundary Marls Unit (named as the "Margas de Transición" Unit by Aguilar et al. 1971) in the study area. An eustatic fall was followed by a worldwide rise in sea level during the early Cenomanian, which led to the installation of a carbonate platform dominated by tidal facies or even continental deposits of lacustrine facies at the uppermost part of the series.

The correlation of the successions corresponding to the latest Albian-Cenomanian boundary is difficult due to numerous lateral facies changes. In this context, the Capa de Chera Unit has been identified by Segura et al. (1994) in the Puerto de San Just section and also dated in the vicinity of 


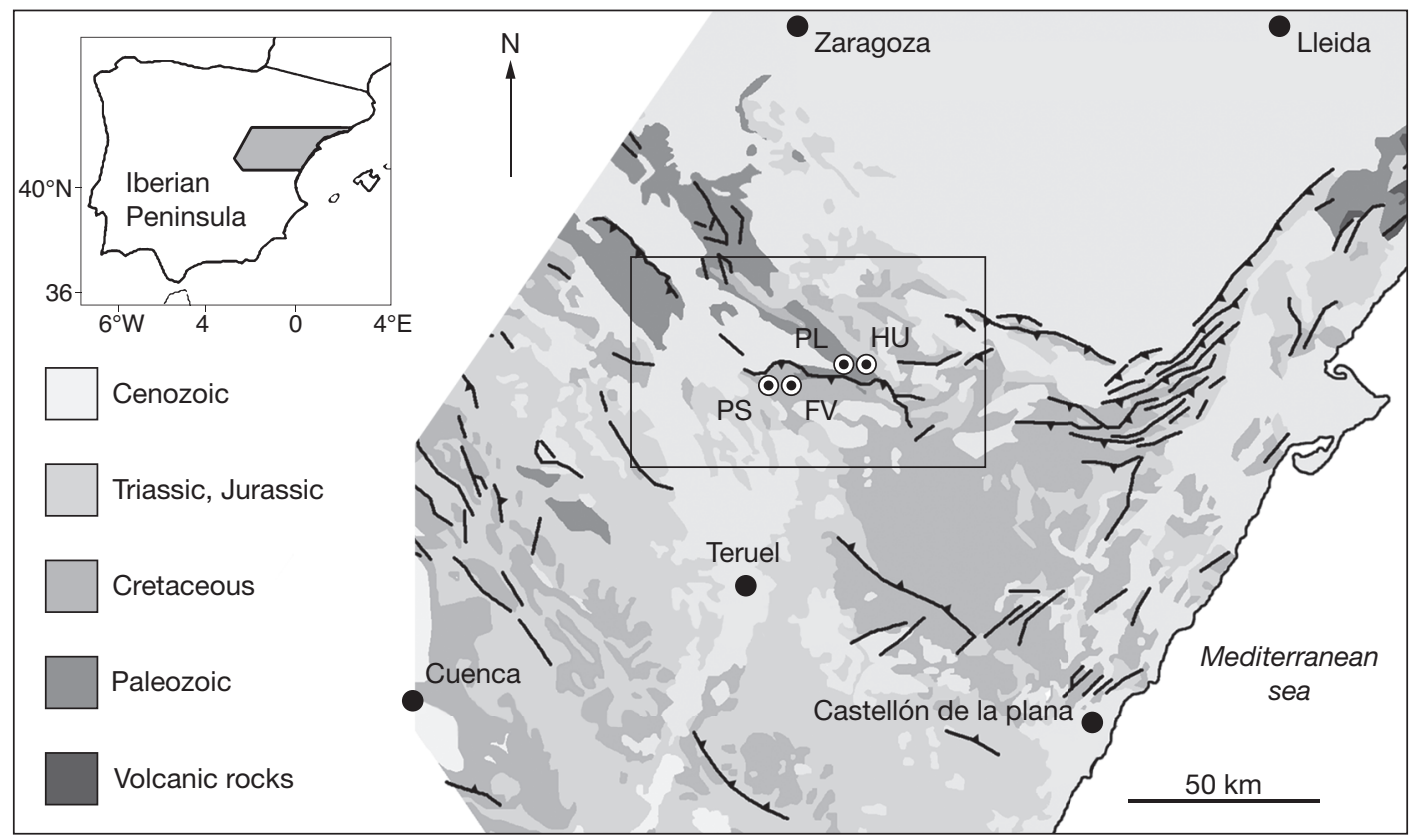

FIG. 1. - Geological map of the Aragonese Branch of the Iberian Chain from Teruel, Spain, with placement of the sections marked as circles with inner dots: FV, Fuente del Vaso; HU, Huesa del Común; PL, Plou; PS, Puerto de San Just.

Huesa del Común village (both places located in Teruel province, northeastern Spain) as early-middle Cenomanian. In the area of Huesa del Común the succession consists of green marls with abundant ostreids, nodular limestones and laminated limestones and dolomites with tractive structures, where marls are more abundant towards the base while the dolomites predominate at the top of the succession (Figs 1; 2).

The base of the Capa de Chera unit changes laterally into the Utrillas Formation (Vilas et al. 1982), the top to the Dolomías de Alatoz Formation and the Calizas de Losa Member of the Aras de Alpuente Formation (Gil et al. 2004). In addition, it presents great similarities with the informal Margas de Pinarueco unit of the Mosqueruela Formation (Canérot et al. 1982). Due to the difficulty of correlating the numerous lateral facies changes of the Capa de Chera unit, we have followed the work of Aguilar et al. (1971) in the Puerto de San Just area, using the informally defined Boundary Marls unit for this study.
The Mosqueruela Formation, overlying the Boundary Marls unit, has been dated as early Cenomanian with orbitolinids (Neumann \& Schröeder 1985; Calonge 1989; García et al. 1989). Moreover, sediments representing the Boundary Marls Unit have been assigned to the late Albian by the presence of the ammonoid Knemiceras ubligi Choffat, 1886 northeast of the Arroyofrío locality, province of Teruel (Geyer 1995). However, the exact stratigraphic level where Geyer found this species is not clear; hence, these cannot be used to provide a reliable age for this unit. More integrated approaches using palynomorphs and marine fauna (ammonoids and foraminifers) are needed in future high-resolution study to confirm this age.

\section{GEOLOGICAL SETTING}

The Boundary Marls Unit at the Aragonese Branch of the Iberian Range is placed between the Utrillas (Aguilar et al. 1971) and the Mosqueruela forma- 


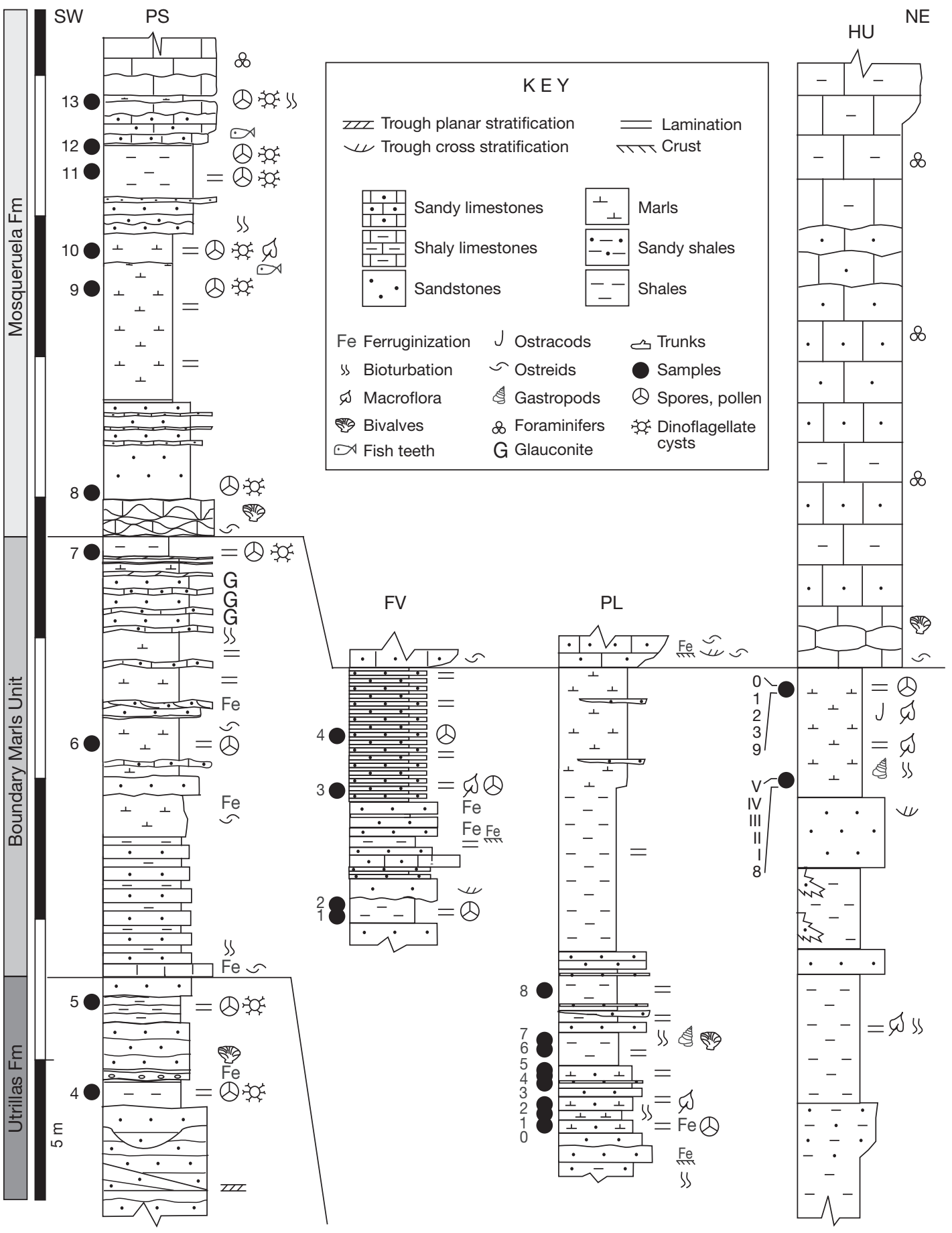

FIG. 2. - Correlation of the four sections studied. Abbreviations: PS, Puerto de San Just; FV, Fuente del Vaso; PL, Plou; HU, Huesa del Común. 


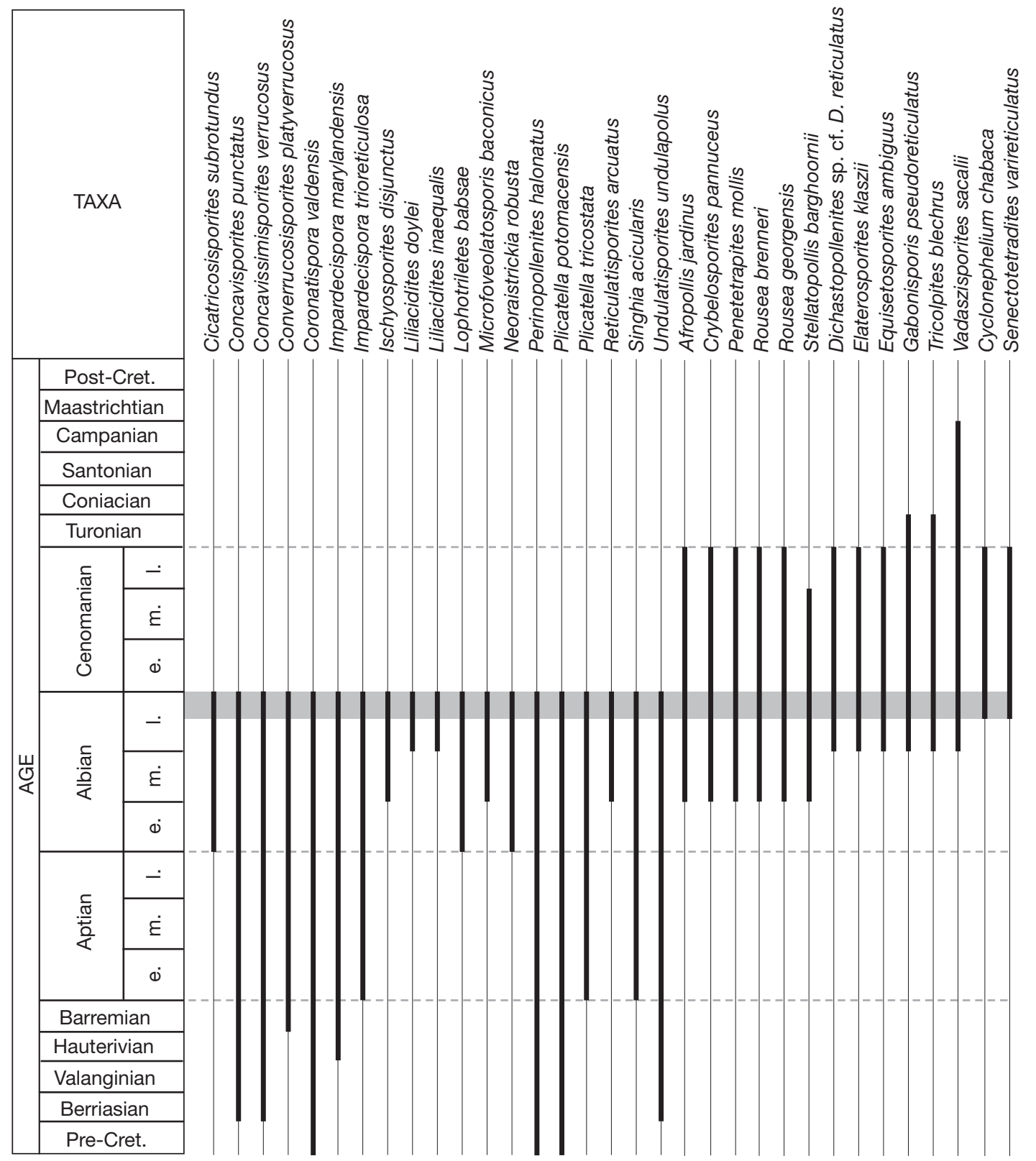

FIG. 3. - The palynostratigraphic distribution, for the presence of the individual spores and pollen grains identified within the positive 21 samples, based on the previous available literature.

tions (Canérot et al. 1982). The underlying Utrillas Formation, late Albian in age (Villanueva-Amadoz et al. in press), has been interpreted as fluvial deposits with the presence of sequences of point bars and flood plains. The Boundary Marls Unit is an informal unit, showing a transition from fluviatile to marine environments. The overlying Mosqueruela Formation consists of limestones and marls with 
ostreids and orbitolinids, which has been interpreted as shallow marine deposit.

The Boundary Marls Unit constitutes the base of the depositional sequence K2.2 of the late Albianearly Cenomanian (Querol 1990). This deposition is the result of the second post-rifting process of latest Albian to early Cenomanian age related to rotation of the Iberian plate and Tethyan and Central Atlantic spreading (Salas 1987; Salas \& Casas 1993).

This unit is composed of greyish to green laminated marls intercalated with marly limestones and dolomitic limestones with ostracods, plant remains and lamellibranchs. This informal unit together with the lower part of the calcareous Upper Cretaceous succession were interpreted as deposited in a lagoon complex with possible estuary-type transitional deposits according to Pardo \& Villena (1979).

Four sections were studied (Fig. 1) in the Maestrat Basin of the Aragonese Branch of the Iberian Range (Eastern Iberian Chain), two corresponding to the Aliaga Sub-basin (Puerto de San Just, PS; Fuente del Vaso, FV) and two to the Oliete Sub-basin (Plou, PL; Huesa del Común, HU). Below we present a brief summary of some of the relevant lithological and paleophytogeographical aspects of the sections sampled in this study (Fig. 2).

\section{Puerto De SAN Just SECTION (PS)}

The Boundary Marls Unit is represented in this section by a $7 \mathrm{~m}$ thick succession of laminated green marlstones with occasional levels containing unidentifiable macrofloral remains, intercalated with limestones. The overlying Mosqueruela Formation consists of $2 \mathrm{~m}$ of yellowish limestones with ostreids. The underlying Utrillas Formation in the same section has been previously described by Villanueva-Amadoz et al. (2009).

\section{Fuente del VASO SECTION (FV)}

The stratigraphic succession of the Boundary Marls Unit at Fuente del Vaso shows three distinct intervals (Fig. 2). The lowest, about $10 \mathrm{~m}$ thick, consists at the base of a white, channelled, medium-grained sandstone alternating with grey claystone that changes upward into a succession composed mainly of white, medium-grained sandstone with interbedded grey claystones and sandy shales. The next interval, about $10 \mathrm{~m}$ thick, is formed by a succession of finely laminated white sandstone and grey claystone with macroflora remains. The upper interval, $1 \mathrm{~m}$ thick, is represented by yellowish sandy limestones with ostreids of the Mosqueruela Formation, which may correspond to a tidal channel deposit.

\section{Plou SECTION (PL)}

The stratigraphic succession of the Boundary Marls Unit at Plou shows two distinct intervals (Fig. 2). The lowest, about $7 \mathrm{~m}$ thick and overlying the Utrillas Formation, consists of finely laminated marlstone and claystone alternating with fine-grained sandstone, representing sedimentation in a shallow freshwater lake with occasional clastic input. Levels from the lowest interval provided the aquatic angiosperm macrofossils Klitzschophyllites choffatii (Saporta sensu Teixeira) Gomez, Coiffard, Sender, Martín-Closas, Villanueva-Amadoz \& Ferrer, 2009 (Gomez et al. 2009) and Ploufolia cerciforme Sender, Gomez, Diez, Coiffard, Martín-Closas, Villanueva-Amadoz \& Ferrer, 2010 (Sender et al. 2010). The upper interval, up to $10 \mathrm{~m}$ thick, is a monotonous succession of massive claystone and sandy channels, interpreted to

FIG. 4. - Distribution of Afropollis jardinus Doyle, Jardiné \& Doerenkamp, $1982(\bullet)$ and Cyclonephelium chabaca Below, 1981 ( $\star$ ). The palaeogeographic map was created using the ODSN Plate Tectonic Reconstruction Service (Hay et al. 1999) back to 100 My (late Albian) in an orthographic projection: Afropollis jardinus, Laurasia: 1, Mons Basin (Yans et al. 2007), Belgium; 2, Bohemia (Pacltová \& Lashin 1998), Czech Republic; 3, Marches-Ombrie Basin (Fiet 1999; Fiet \& Pons 1998), Italy; 4, Charentes, île Madame (Dejax \& Masure 2005; SNEA[P]; Doyle et al. 1982), France; 5, Ecommoy (Azéma et al. 1972), France; 6, Neau (Azéma et al. 1972), France; 7, La Bironnière (Azéma et al. 1972), France; 8, Anjou (Yans et al. 2007), France; 9, between Lisbon and Foz da Folcao and on both sides of the Serra de Sintra (Hasenboehler 1981), Portugal; 10, Iberian Chain (this study), Spain; North America: 11, Lake Texoma, Oklahoma (Wingate 1980), USA; Gondwana, South America: 12, Sergipe and Alagoas Basins (Müller 1966; Regali et al. 1974a, b; Herngreen 1975), Brazil; 13, Maranhão Basin (Müller 1966; Regali et al. 1974a, b; Lima 1982), Brazil; 14, Araripe Basin (Pons et al. 1996), Brazil; 15. Barreirinhas Basin (Herngreen 1973, 1975; Regali et al. 1974a, b), Brazil; 16, northern Piauí Basin (Regali et al. 1974a, b), Brazil; 17. Ceará Basin (Regali et al. 1974a, b; Lima 1979), Brazil; 18, North R.G. and Potiguar Basins (Regali et al. 1974a, b; Campos et al. 1994), Brazil; 19, Espírito Santo, Brazil; 20, Rio de Janeiro, Brazil; 21, Jequitinhonha/Cumuruxaliba Basins; 19-21, (Regali et al. 1974a, b), Brazil; 22, San Luis de Gaceno (Dueñas Jiménez 1989; Herngreen \& Dueñas Jiménez 1990), Colombia; 23, Pamplona (Dueñas 


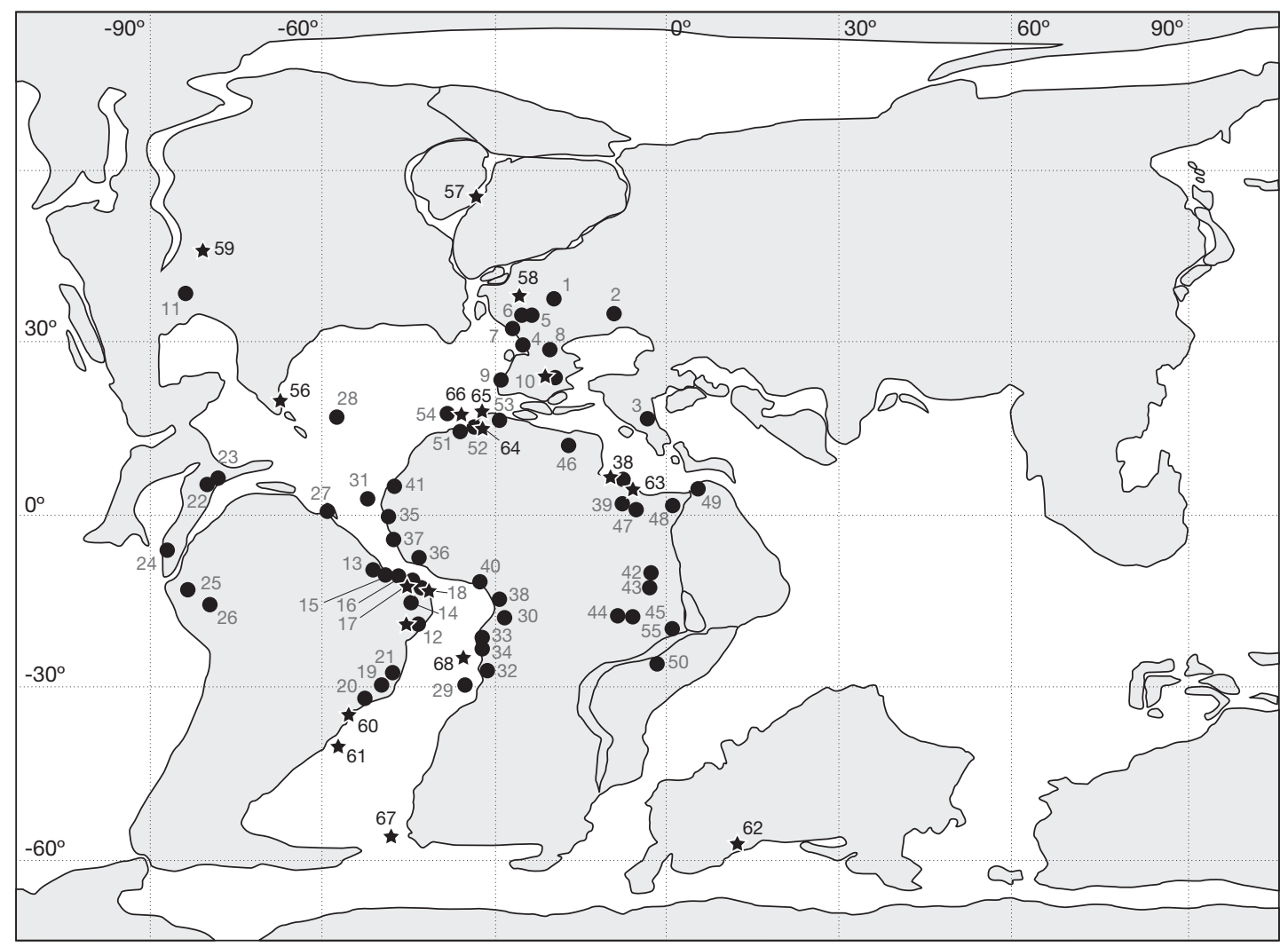

Jiménez 1989), Colombia; 24, Oriental Basin (Jaillard 1997), Ecuador; 25, Montaña region (Brenner 1968), Peru; 26, Oriente Basin (Robertson Research 1990), Peru; 27, (Belsky et al. 1975), Suriname; 28, DSDP sites 418A/core10, 418B/core 28 and 417D/core 19 (Hochuli \& Kelts 1980), southwestern North Atlantic; West Africa: 29, offshore, DSDP Site 364 (Morgan 1978; Doyle et al. 1982), Angola; 30, Douala Basin (SNEA[P]; Doyle et al. 1982), Cameroon; 31, DSDP Site 367, cores 21 and 23, 150 km west of Guinea Bissau (Kotova 1978; Doyle et al. 1982), Cape Verde; 32, SNEA(P); Doyle et al. 1982, Congo; 33, North Gabon (SNEA[P]; Doyle et al. 1982), Gabon; 34, Doukaga 1980, north of Mayumba; 35, SNEA(P); Doyle et al. 1982, Guinea-Bissau; 36, Bérou I, Port Bouet I, and Groguida 1 deep wells (SNEA[P]; Doyle et al. 1982), Ivory Coast; 37, SNEA(P); Doyle et al. 1982, Liberia; 38, wells A1-28 core 3, A1-36, B1-36, Bla-18 and A1-45, North Cyrenaica (Thusu \& Van der Eem 1985 ; Thusu et al. 1988; Uwins \& Batten 1988), Libya; 39, wells A1a-117, Ai-NC-92, B1-2, between Benghazi and Tobruk, flanks of the Abakaliki Anticlinorium and flanks of the Lamurde Anticline and the Dadyia Syncline (Legoux 1978; Allix 1982; SNEA[P] Doyle et al. 1982; Uwins \& Batten 1988), Libya; 40, borehole Ojo-1, 25 km west of Lagos, Benin Basin (Jan du Chêne et al. 1978; Klasz \& Jan du Chêne 1978), Nigeria; 41, M'Bour 1 well (Jardiné \& Magloire 1965), Senegal; 42, Dongola-Wadi Muqaddam area (Schrank 1990), Sudan; 43, west of Umm Badda (Awad 1994), Sudan; 44, Muglad, Sudan; 45, Melut (Kaska 1989), Sudan; North Africa-Middle East: 46, SNEA(P); Doyle et al. 1982, Algeria; 47, Qattara Depression and surroundings (Saad 1978; Schrank \& Ibrahim 1995; Ibrahim 1996, 2002a; Mahmoud \& Moawad 2000; Zobaa et al. 2008; Atawy 2009; El-Beialy et al. 2010), Egypt; 48, Kabrit-1 and Abu Hammad-1 wells, near Ismailia (Ibrahim et al. 2001) and Tahrir well, Western Desert (Sultan 1978), Egypt; 49, Sample Ramon Maále Haázamáut (SNEA[P]; Herngreen 1975; Doyle et al. 1982), Israel; 50, Majunja Basin [SNEA(P); Doyle et al. 1982], Madagascar; 51, Tantan-Tarfaya and Tamaloukte localities (Bettar \& Méon 2001, 2006), Morocco; 52, samples TSK02 to TSK43 (Tiskatine), samples AOR15 to AOR40 (Aouerga), and samples ADZ07 and ADZ10 (Adouz), Agadir-Essaouira Basin (Bettar \& Méon 2006), Morocco; 53, core G 503 (Tisirène) and core G 488 (Meloussa) (Hochuli 1981), Morocco; 54, DSDP Hole 370 (Kotova 1978; Doyle et al. 1982), Morocco; 55, SNEA(P); Doyle et al. 1982, Somalia. Cyclonephelium chabaca, Laurasia: 56, DSDP Holes 627B and 635B (Masure 1988), Bahamas; 57, offshore (Williams 1975), Canada; 58, Isle of Wight (Clarke \& Verdier 1967), Great Britain; 10, Iberian Chain (this study), Spain; 59, central and southern Kansas (Bint 1986), USA; Gondwana: 12, Sergipe Basin (Masure \& Vrielynck 2009), Brazil; 17, Ceará Basin (Lana \& Roesner 2002; Arai 2005), Brazil; 18, Potiguar Basin (Masure \& Vrielynck 2009), Brazil; 60, 1-SPS-14A well, Santos Basin (Masure \& Arai 2003; Arai 2005), Brazil; 61, offshore site 203 (Masure \& Vrielynck 2009), Brazil; 62, Cauvery Basin (Khowaja-Ateequzzaman \& Garg 2002), India; 63, site 15 (Masure \& Vrielynck 2009), Libya; 38, well A1-45 core 1 (Uwins \& Batten 1988), Libya; 64, KV-Blätter Tamri and Tarhazoute, Chichaoua I and Timinoun sections (Below 1981), Morocco; 65, sites 18 and 19 (Masure \& Vrielynck 2009), Morocco; 66, DSDP Holes 545 and 547A, Mazagan Plateau (Below 1984), Morocco; 67, offshore, DSDP Leg 40 site 361 (Davey 1978), South Africa; 68, offshore Cabinda (Nelson 2008), Angola. 
reflect deposition in distal alluvial fans. The top of the succession is overlain by the sandy limestone of the Mosqueruela Formation. These beds contain abundant bioclasts of marine molluscs such as oysters, and are interpreted as a near-shore high-energy marine deposit (Canérot et al. 1982).

\section{Huesa del COMÚN SECTION (HU)}

In the Huesa del Común section (HU) the Boundary Marls Unit consists of $5 \mathrm{~m}$ of finely laminated grey marls with ostracods, gastropods and plant remains. It has been interpreted as a shallow freshwater lake with occasional clastic input. At the top, the Mosqueruela Formation includes a thick succession (23 m) of nodulose limestones with ostreids at the base which passes into sandy limestones and shaly limestones toward the top.

\section{MATERIAL AND METHODS}

A total of 34 samples were processed following the standard processing technique used in palynology, employing an acid digestion with $\mathrm{HCl}, \mathrm{HF}$ and $\mathrm{HNO}_{3}$. Finally, the residue was filtered through a $100 \mu \mathrm{m}$ mesh sieve. Only 21 samples proved to be positive (Appendix).

The slides were analysed at the Muséum national d'Histoire naturelle (Paris) under a Nikon Eclipse $80 \mathrm{i}$ light microscope using a differential interference contrast objective and equipped with a Nikon Coolpix 5400. Palynomorphs were photographed at a magnification of $\times 750$, except for pollen grains photographed at $\times 1000$. Several separate optical section pictures were taken for each palynomorph and depth of field was then reconstructed using the free image stacking program CombineZM (Bercovici et al. 2009). Scanning electron micrographs were taken at Vigo University using a SEM Phillips XL 30.

Each pollen grain is designated first with the acronym of the section and its stratigraphic level, followed by the slide number and finally the England Finder coordinates.

\section{COMPOSITION OF PALYNOLOGICAL ASSEMBLAGES}

The four studied sections yielded very rich palynological assemblages with a high diversity of species (Appendix; Figs 8-16).

The most noteworthy aspect of this study concerns the variabity of the palynological assemblages, which may be explained in part by facies control. It is evident that the taphonomic (biostratinomical) processes involved in the particular sedimentological setting within this lagoon complex determined the composition of the palynological assemblage.

It ought to be noted that in the present paper Afropollis has been described as angiosperm pollen grain as there is not yet any consistent data that relate to any known group. However, the interpretation of Afropollis as an angiosperm has been questioned based on the finding of this pollen in microsporangia of uncertain but probably non-angiospermous affinities (Friis et al. 1999) and its gymnosperm-like laminated endexine structure (Doyle 2000).

FIG. 5. - Distribution of Asbeckiasporites Von der Brelie, 1964 ( $\star$ ), Elaterosporites klaszii (Jardiné \& Magloire) Jardiné, 1967 (•) and Vadaszisporites sacalii Deák \& Combaz, $1967(\mathbf{\Delta})$. The palaeogeographic map was created using the ODSN Plate Tectonic Reconstruction Service (Hay et al. 1999) back to 100 My (late Albian) in an orthographic projection. Asbeckiasporites, Laurasia: 69, Peace River, Alberta (Singh 1971), Canada; 70, Saskatchewan and Manitoba (Playford 1971), Canada; 71, Sauerland (von der Brelie 1964), Germany; 3, Marches-Ombrie Basin (Fiet \& Pons 1998; Fiet 1999), Italy; 72, Caucase, Russia; 73, Donetz; 107, Southern Baltic Sea; 108, Russian platform; 109, Dniepr-Donetz depression; 110, pre-Black Sea depression; 111, eastern Caucase; 112, pre-Caspian depression; 113, western Kazakhstan; 72, 73, 107-113, Bolkhovitina 1966; Voronova 1971; Herngreen \& Chlonova 1981, Russia; 10, Iberian Chain (this study), Spain; Gondwana: 62, borehole RKK-1, Damodar Basin (Vijaya 2011), India. Elaterosporites klaszii, Laurasia: 28, DSDP Hole 417 (Hochuli \& Kelts 1980), Bermudas; 2, Bohemia (Pacltová \& Lashin 1999), Czech Republic; 74, Cismon section (Hochuli 1981), Italy; 3, Marches-Ombrie Basin (Fiet \& Pons 1998; Fiet 1999), Italy; 10, Iberian Chain (this study), Spain; 75, Breggia section (Hochuli 1981), Switzerland; 76, recycled palynomorph, Ragley Lumber D1 well, Louisiana (Gregory \& Hart 1992), USA; Gondwana, South America: 12, Calumbi (Ca-1-Se) borehole and sample 9704593 (137.7 m) GTP-17-SE, Sergipe Basin (Boer et al. 1965; Herngreen 1975; Carvalho 2001), Brazil; 15, 1-QS-1-MA, Mandacaru (I-MU-I-MA), Humberto de Campos (2-HCst-I-MA) and Barreirinhas (2-BAst-I-MA) boreholes, Barreirinhas Basin (Boer et al. 1965; Herngreen 1973, 1975; Regali et al. 1974a, b; Dino et al. 1999), Brazil; 77, continental platform of Maranhão and São Luis Basin (Regali et al. 1974a, b; Ferreira et al. 2008), Brazil; 78, core 


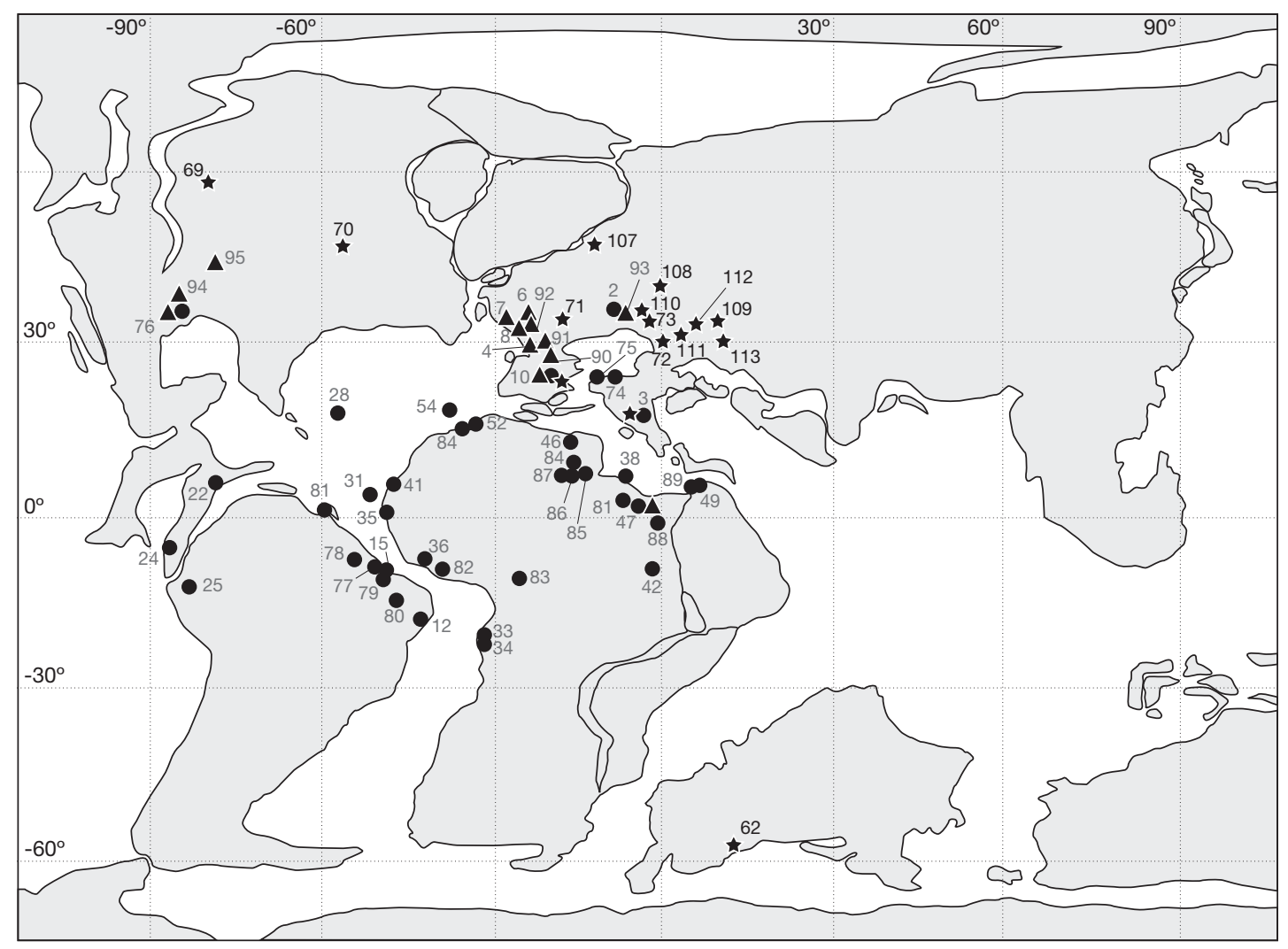

16 of borehole Bj-I-PA, Marajó/Badajós Basin (Boer et al. 1965; Herngreen 1975), Brazil; 79, Parnaíba Basin (Dino et al. 1999), Brazil; 80, GTP-24-SE, Taquari/Vassouras, Piauí Basin (Carvalho 2001), Brazil; 22, San Luis de Gaceno (Dueñas Jiménez 1989) and between Bogotá and Villavicencio (Pons 1988; Herngreen \& Dueñas Jiménez 1990), Colombia; 24, Rio Misahualli and Rio Chapiza, Oriental Basin (Jaillard 1997; Dino et al. 1999), Ecuador; 25, Peru Mountains, Cerros Contamana, Cushabatay and Campanquiz (Brenner 1968, 1976; Müller \& Aliaga 1981; Vara 2003), Peru; 81, DSDP site 144 leg 14 (Habib 1972), Suriname; West Africa: 31, DSDP Site 367, cores 21 and 23, 150 km west of Guinea Bissau (Kotova 1978), Cape Verde; 33, Boltenhagen 1965; Jardiné 1967; Klasz \& Micholet 1972, Gabon; 34, north of Mayumba (Doukaga 1980), Gabon; 82, Tano 1-1 and 1S-3AX wells, Tano Basin (Atta Petters \& Salami 2006), Ghana; 35, SNEA(P); Doyle et al. 1982, Guinea Bissau; 36, wells Gr1, Gt, Tt1, Bt1, Bu1 and Bérou 1, Lahou-Abidjan localities (Vachey \& Jardiné 1962; Jardiné \& Magloire 1965; Jardiné et al. 1974; SNEA[P]; Doyle et al. 1982), Ivory Coast; 38, A1-28 core 3 , A1-36, B1-36, Bla-18, Ala-117, Ai-NC-92, B1-2and A1-45 wells, North Cyrenaica (Thusu \& Van der Eem 1985; Uwins \& Batten 1988), Libya; 83, Upper Benue Graben (Allix 1983; Abubakar et al. 2006), Nigeria; 84, Septentrional Province (ZB 1 well), southern Tunisian area, Sahara; 85, Te 1 and Sb 1 wells, Gassi-Touil area, Sahara; 86, Ar 101, GT 3, Mf 101 and Aa 1 wells, Tinrhert area and Occidental area, Sahara; 87, St 1 and Df 1 wells (Reyre 1973), Sahara; 41, Bb1, DN1, DN2, DN5, 3, 4, 7, 6, 8, Sa1, Do.1, Do.2, Do.3, Mb.1, DS1, Po.1, Ye.3 wells, east of Dakar (Stover 1963; Jardiné \& Magloire 1965; Jardiné 1967), Senegal; 42, Dongola-Wadi Muqaddam area (Schrank 1990, 1994), Sudan; 44, Muglad, Sudan; 45, Melut (Kaska 1989), Sudan; North Africa-Middle East: 46, SNEA(P); Doyle et al. 1982, Algeria; 88, well Umbarka IX, Kharga, Nile Delta area (Saad 1978), Egypt; 47, Qattara Depression and surroundings (Sultan 1978, 1987; Penny 1991, 1992; Schrank \& Ibrahim 1995; Ibrahim 1996, 2002a; Mahmoud \& Moawad 2000; Atawy 2009; El-Beialy et al. 2010), Egypt; 89, north of Negev (Horowitz 1970), Israel; 49, Sample Ramon Maále Haázamáut [SNEA(P); Herngreen 1975; Doyle et al. 1982], Israel; 51, Tantan-Tarfaya and Tamaloukte localities (Bettar \& Méon 2001, 2006), Morocco; 52, samples TSK04 to TSK43 (Tiskatine), samples AOR27 and AOR38 (Aouerga), Agadir-Essaouira Basin (Bettar \& Méon 2006), Morocco; 54, DSDP Hole 370 (Kotova 1978), Morocco. Vadaszisporites sacalii, Laurasia: 4, Saint-Romain-de-Benêt and Archingeay quarry, Charente-Maritime (Deák \& Combaz 1967; Dejax \& Masure 2005), France; 6, Neau (Azéma \& Ters 1971), France; 7, La Bironnière, La Bloire, La Laiterie, Les Gaucheries, Bois-Soleil and Vendée (Azéma \& Ters 1971), France; 8, Anjou (Pons, unpublished observations), France; 90, Laudun, Montlaux and Col des Robines (Médus \& Triat 1969; Médus 1970), France; 91, Simeyrols, La Malvie (Azéma \& Ters 1971), France; 92, Le Revest (Azéma \& Ters 1971), France; 93, Transdanubia (Juhász 1975, 1983; Góczán \& Siegl-Farkas 1990); Uppony Montains, south part of the Great Hungarian Plain and the Trans-Tisza Region (Góczán \& Siegl-Farkas 1990), Hungary; 10, Iberian Chain (this study), Spain; 76, Louisiana, USA; 94, Mississippi, USA; 95, near Sargeant Bluff in lowa (Ravn 1986; Ludvigson et al. 2010), USA; Gondwana (Turonian-Coniacian): 47, well GPTSW-7, north Western Desert (El-Beialy et al. 2010), Egypt. 
In the Puerto de San Just section (PS) there is a more marked marine influence than in other sections, evidenced by green marls with an interbedding of nodular bioclastic limestones with ostreids. The palynological results also attest this increasing marine input by a gradual increase of dinoflagellate cysts, mainly composed of Cyclonephelium chabaca, which is the dominant palynomorph at PS 13, and, to a lesser extent, by Oligosphaeridium pulcherrimum, Florentinia sp. and other indeterminate cysts. This trend is also associated with an upward decrease of gymnosperm and angiosperm pollen grains and also of spores. The gymnosperm pollen grains, which are abundant at the base of the unit, consist mainly of Classopollis spp. followed in abundance by Exesipollenites tumulus, Taxodiaceaepollenites hiatus, Araucariacites australis, Spheripollenites psilatus, Alisporites grandis, Applanopsis spp., Podocarpidites biformis, Balmeiopsis limbata, Singhia spp., Cycadopites spp., Cedripites canadensis and Perinopollenites halonatus. The second most abundant group is that of pteridophyte spores, which are mainly composed of Cyathidites spp., Patellasporites spp., and, in lower proportions, Gleicheniidites senonicus, Gabonisporis spp., Matonisporites equiexinus, Deltoidospora psilostoma, Dictyophyllidites harrisii, Laevigatosporites haardtii, Polycingulatisporites reduncus, Taurocusporites segmentatus, Cicatricosisporites spp., Camarozonosporites insignis, Asbeckiasporites sp., Crybelosporites pannuceus, Plicatella spp., Ruffordiaspora australiensis, Anapiculatisporites sp., Cibotiumspora juncta, Concavisporites punctatus, Concavissimisporites verrucosus, Converrucosisporites platyverrucosus, Coronatispora spp., Costatoperforosporites foveolatus, Fisciniasporites brevilaesuratus, Leptolepidites verrucatus, Neoraistrickia truncata, Peromonolites spp., Reticulatisporites arcuatus, Undulatisporites undulapolus, Asbeckiasporites sp., Camarozonosporites spp., Anapiculatisporites sp. and Heliosporites sp. Angiosperm pollen grains are also quite abundantly represented by Transitoripollis sp. cf. T. similis, Clavatipollenites spp., Afropollis jardinus, Monosulcites chaloneri, Pennipollis spp. Retimonocolpites dividuus, Stellatopollis barghoornii, Retitricolpites virgeus, aff. Tricolpites crassimurus and Rousea sp. B.

At very low proportions, bryophyte spores are represented by Aequitriradites spinulosus, Triporoletes cenomanianus and T. reticulatus, and there are also spores of algae such as Pterospermella aristotelesii.

The other studied sections (FV, PL, HU) are more generally lacustrine. At the Plou section (PL), the lacustrine character of the deposits is inferred from sedimentological evidence and the aquatic angiosperm macrofossil content. However, the palynological assemblage provides no evidence, due to the scarcity of specimens possibly due to a high clastic input. It is mainly composed of angiosperm pollen grains, which are represented in decreasing order of abundance by Stellatopollis barghoornii, Rousea spp., Tricolpites crassimurus, Afropollis jardinus, Asteropollis sp. cf. A. asteroides, Transitoripollis sp. cf. T. similis, Clavatipollenites spp., Retimonocolpites textus and Similipollis spp. Gymnosperm pollen grains are represented to a lesser extent by Araucariacites australis, Alisporites grandis, Cycadopites spp., Taxodiaceaepollenites hiatus, Balmeiopsis limbata, Equisetosporites ambiguus and Spheripollenites psilatus. Finally pteridophyte spores are characterized by the presence of Cyathidites spp. and Peromonolites sp.

The most lacustrine deposits are recorded from Fuente del Vaso (FV) and Huesa del Común (HU) sections, coinciding with abundant macrofloral remains and high values of Afropollis jardinus.

At the Fuente del Vaso section (FV) there is very low marine influence with the highest abundance of dinoflagellate cysts (represented by undetermined dinoflagellate cysts, Cyclonephelium chabaca, Florentinia sp. and Oligosphaeridium pulcherrimum) being $2.2 \%$ of the total palynological assemblage.

Angiosperm pollen grains are abundant, consisting mainly of Afropollis jardinus, and, to a lesser extent, Clavatipollenites spp., Stellatopollis barghoornii, Penetetrapites mollis, Tricolpites spp., Pennipollis spp., Senectotetradites varireticulatus, Transitoripollis sp. cf. T. similis, Dichastopollenites spp., Echimonocolpites sp. and Striatopollis paraneus. The next most abundant group is the gymnosperm pollen grains, mainly represented by Taxodiaceaepollenites hiatus, followed by Araucariacites spp., Balmeiopsis limbata, Classopollis classoides, Exesipollenites tumulus, Spheripollenites psilatus, Podocarpidites spp., Perinopollenites halonatus, Applanopsis spp., Eucommiidites spp., Alisporites grandis, Cedripites canadensis, Elaterosporites 


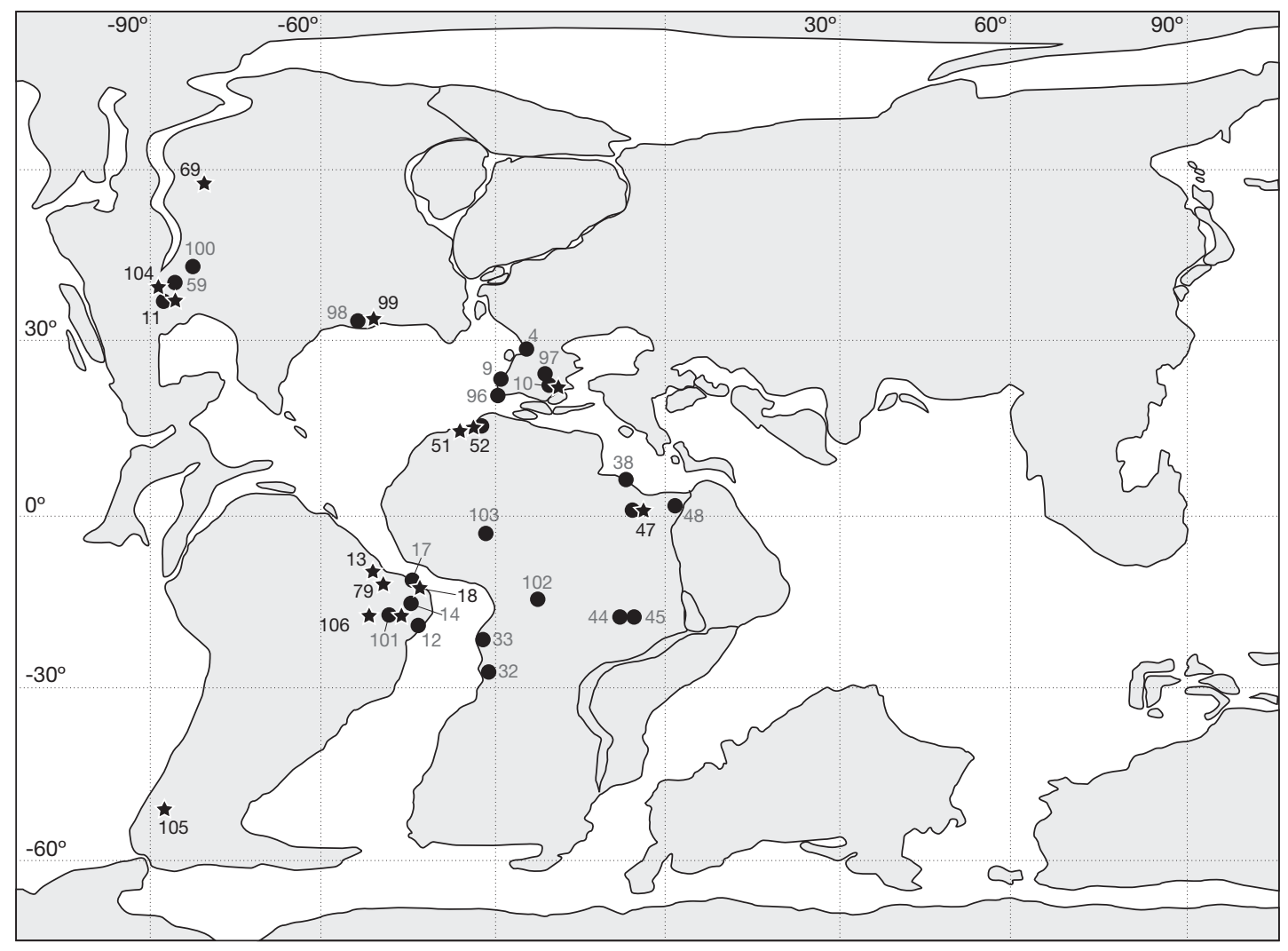

FIG. 6. - Distribution of Penetetrapites mollis Hedlund \& Norris, 1968 ( $\star$ ) and Stellatopollis barghoornii Doyle, $1975(\bullet)$. The palaeogeographic map was created using the ODSN Plate Tectonic Reconstruction Service (Hay et al. 1999) back to 100 My (late Albian) in an orthographic projection. Stellatopollis barghoornii, Laurasia: 4, Charentes (Dejax \& Masure 2005), France; 9, Folcao-Magoito, Baforeira Rana, Barrigudo, Casal da Cova and Magoito-Aguda, near Nazaré (Hasenboehler 1981; Heimhofer et al. 2007), Portugal; 96, Luz (Heimhofer et al. 2007), Portugal; 97, Peñacerrada, Basque-Cantabrian Basin (Barrón et al. 2001), Spain; 10, Iberian Chain (present study), Spain; 11, Oklahoma (Hedlund \& Norris 1968), USA; 98, Virginia, USA; 99, Maryland and Delaware (Doyle et al. 1975; Doyle \& Robbins 1977; Walker \& Walker 1984), USA; 59, Kansas (Ward 1986), USA; 100, Nebraska (Ludvigson et al. 2010), USA; Gondwana: 12, Sergipe Basin (Carvalho 2001), Brazil; 14, Araripe Basin (Pons et al. 1996), Brazil; 17, Pernambuco-Ceará Basin (Lima 1976), Brazil; 18, Potiguar Basin (Campos et al. 1994), Brazil; 101, Chapada do Araripe (Martill et al. 2007), Brazil; 102, Doba Graben (Doyle et al. 1982), Chad; 32, borehole K8, south of Tchiboula (Boltenhagen \& Salard-Cheboldaeff 1987), Congo; 47, Ghazalat-1 (GTX1) well, Qattara Depression (Penny 1991; Schrank \& Ibrahim 1995; Ibrahim 1996, 2002b; Atawy 2009), Egypt; 48, Kabrit-1 well, Bitter Lake (Ibrahim et al. 2001), Egypt; 33, Libreville (Doyle et al. 1977, 1982), Gabon; 38, northern Cyrenaica (Thusu \& van der Eem 1985); well VV1-80/GGG1-59 (Thusu et al. 1988), Libya; 103, Ansongo 1 well, Gao Graben (SNEA[P]; Doyle et al. 1982), Mali; 52, Tiskatine, Agadir-Essaouira Basin (Bettar \& Méon 2006), Morocco; 44, Muglad, Sudan; 45, Melut (Kaska 1989), Sudan; Penetetrapites mollis, Laurasia: 69, southern Alberta (Braman 2001), Canada; 10, Iberian Chain (present study), Spain; 11, Lake Texoma, Bokchito Creek and Marshall County, Oklahoma (Hedlund \& Norris 1968; Srivastava 1975; Wingate 1980), USA; 59, central Kansas (Ward 1986), USA; 99, Delaware (Doyle \& Robbins 1977), USA; 104, Dallas and Waco Texas (Brown \& Pierce 1962), USA; Gondwana: 105, Rio Turbio, Santa Cruz province (De Baldis 1995), Argentina; 13, Maranhão Basin (Lima 1982), Brazil; 18, Potiguar Basin (Dino 1992), Brazil; 79, Parnaíba Basin (Campos et al. 1994), Brazil; 101, Chapada do Araripe (Martill et al. 2007), Brazil; 106, Fazenda Muzinho, Floriano (Lima \& Campos 1980), Piaui, Brazil; 47, Mersa Matruh borehole, North West Desert (Penny 1991), Egypt; 51, Tamaloukte, Morocco; 52, Tiskatine and Aouerga in Agadir-Essaouira Basin (Bettar \& Méon 2001, 2006), Morocco.

klaszii, Cycadopites spp., Parvisaccites radiatus, Ephedripites multicostatus, Equisetosporites ambiguus and Singhia acicularis. The assemblage also presents a high abundance of pteridophyte spores, mainly Cyathidites spp., Peromonolites sp., Matonisporites equiexinus, Gabonisporis spp., Gleicheniidites senonicus 
and, in lower proportions, Dictyophyllidites harrisii, Deltoidospora spp., Ruffordiaspora australiensis, Concavissimisporites verrucosus, Laevigatosporites haardtii, Cicatricosisporites spp., Plicatella spp., Impardecispora spp., Patellasporites spp., Biretisporites potoniaei, Camarozonosporites spp., Neoraistrickia robusta, Todisporites spp., Crybelosporites spp., Nodosisporites spp., Ischyosporites disjunctus, Klukisporites sp. cf. K. foveolatus, Microreticulatisporites crassiexinous, Vinculisporites flexus, Cibotiumspora juncta, Concavisporites punctatus, Distaltriangulisporites sp., Leptolepidites verrucatus, Lophotriletes babsae, Microfoveolatosporis baconicus, Perinomonoletes sp., Reticulisporites sp. and Undulatisporites undulapolus. Less frequently, spores of freshwater algae are also present (Schizophacus parvus, Schizosporis spp., Pterospermella aristotelesii), together with bryophyte spores (Aequitriradites spinulosus, Antulsporites varigranulatus, Stereisporites antiquasporites, Triporoletes laevigatus).

The palynological assemblage of the Huesa del Común section (HU) also shows very low proportions of dinoflagellate cysts. However, there is a clear predominance of angiosperm pollen grains consisting mainly of Afropollis jardinus, with lower quantities, listed in decreasing abundance, of Clavatipollenites spp., Tricolpites spp., Retimonocolpites fragilis, Stellatopollis barghoornii, Transitoripollis sp. cf. T. similis, Liliacidites spp., Pennipollis spp., Dichastopollenites dunveganensis, Penetetrapites mollis, Rousea sp., Monosulcites minimus and Hammenia fredericksburgensis. In addition the gymnosperm pollen grains are represented in low proportions in decreasing abundance by Araucariacites australis, Spheripollenites psilatus, Alisporites grandis, Taxodiaceaepollenites hiatus, Ephedripites multicostatus, Eucommiidites troedssonii, Applanopsis spp., Classopollis classoides, Cycadopites sp. and Podocarpidites ornatus. Algae spores are also found represented by Schizophacus spp. and Pterospermella aristotelesii, while pteridophytes are characterized by terrestrial Cyathidites spp., Camarozonosporites insignis, Peromonolites sp. and freshwater Crybelosporites pannuceus.

\section{PALYNOSTRATIGRAPHY}

The palynostratigraphic distribution, based on the previous available literature, for the presence of the individual spores and pollen grains identified within the 21 samples is shown in Figure 3. The Boundary Marls Unit includes some taxa that are not known to extend above the Albian-Cenomanian boundary such as: Cicatricosisporites subrotundus, Concavisporites punctatus, Concavissimisporites verrucosus, Converrucosisporites platyverrucosus, Coronatispora valdensis, Impardecispora marylandensis, I. trioreticulosa, Ischyosporites disjunctus, Liliacidites doylei, L. inaequalis, Lophotriletes babsae, Microfoveolatosporis baconicus, Neoraistrickia robusta, Perinopollenites halonatus, Plicatella potomacensis, P. tricostata, Reticulatisporites arcuatus, Singhia acicularis and Undulatisporites undulapolus.

Some other taxa are widely distributed above the early-middle Albian boundary, such as Afropollis jardinus, Crybelosporites pannuceus, Penetetrapites mollis, Rousea brenneri, $R$. georgensis distributed from the middle Albian to Cenomanian and Stellatopollis barghoornii from the middle Albian to middle Cenomanian. Moreover, there are abundant taxa distributed above the middle-late Albian boundary, such as Dichastopollenites sp. cf. D. reticulatus, Elaterosporites klaszii and Equisetosporites ambiguus present through the late Albian to Cenomanian, Tricolpites blechrus from late Albian to Turonian, Vadaszisporites sacalii from late Albian to early Campanian, and Gabonisporis pseudoreticulatus from late Albian to earliest Turonian. Taxa restricted to the latest Albian-Cenomanian interval in Laurasia include Cyclonephelium chabaca and Senectotetradites varireticulatus.

The presence of the palynomorphs cited above allows us to establish a latest Albian age for this unit (shaded rectangle in the Figure 3).

\section{PALAEOPHYTOGEOGRAPHICAL AND PALAEOECOLOGICAL IMPLICATIONS}

\section{PALAEOPHYTOGEOGRAPHY}

The rapid diversification of early angiosperms after a phase of pronounced environmental instability was favoured by the extensive marine transgressions of the early Aptian and latest Albian-Cenomanian (Haq et al. 1988) permitting ecological strategies of early angiosperms and their dominance in coastal disturbed habitats (Doyle et al. 1982). The upper- 


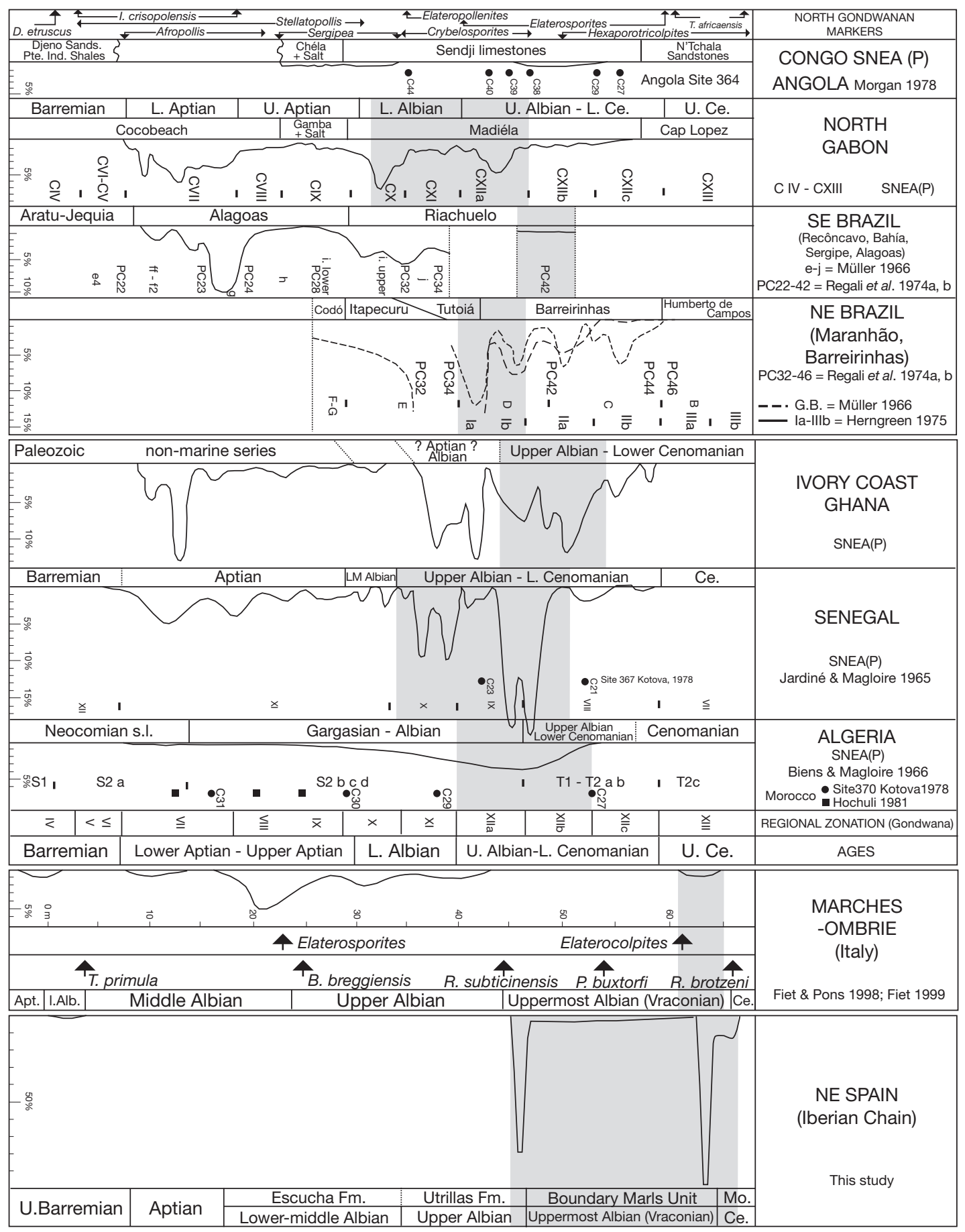

FIG. 7. - Quantitative distribution of the genus Afropollis Doyle, Jardiné \& Doerenkamp, 1982 in Gondwana and southern Laurasia (modified after Doyle et al.1982). 


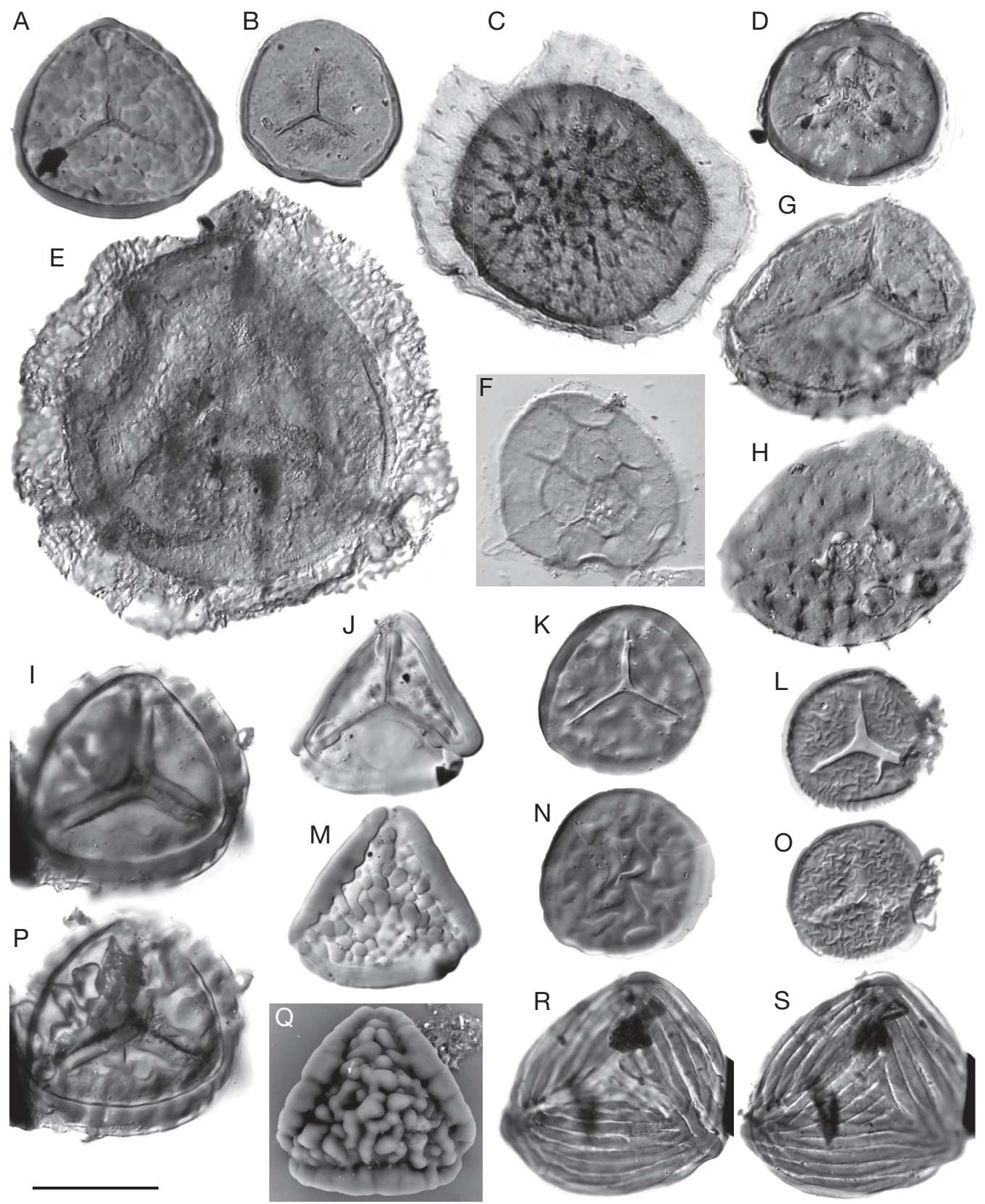

FIG. 8. - A, Antulsporites varigranulatus in proximal face (VA2B4Q524); B, Stereisporites antiquasporites in proximal view (VA2A3H44); C, Aequitriradites spinulosus in distal view (FV2A1K19); D, Triporoletes laevigatus in proximal view (FV4 3_3R4); E, Aequitriradites sp. 2 in distal view (PS8a2_5F424); F, Triporoletes cenomanianus in proximal view (PS8bA3T573); G, H, Anapiculatiporites sp. in proximal (G) and distal (H) views (PS126P414); I, P, Camarozonosporites sp. 2 in proximal (I) and distal (P) views (FV3 3_3M352); J, M, Asbeckiasporites sp. in proximal (J) and distal (M) views (PS121X291); K, N, Camarozonosporites sp. 1 in proximal (K) and distal (N) views (PS124S56); L, O, Camarozonosporites insignis in proximal (L) and distal (O) views (PS10c4M523); Q, Asbeckiasporites sp. in distal view (PS10); R, S, Cicatricosisporites sp. cf. Anemia exilioides in proximal (R) and distal (S) views (FV4B1F58). Scale bar: A-E, G-P, $\mathrm{R}, \mathrm{S}, 20 \mu \mathrm{m} ; \mathrm{F}, \mathrm{Q}, 10 \mu \mathrm{m}$. 

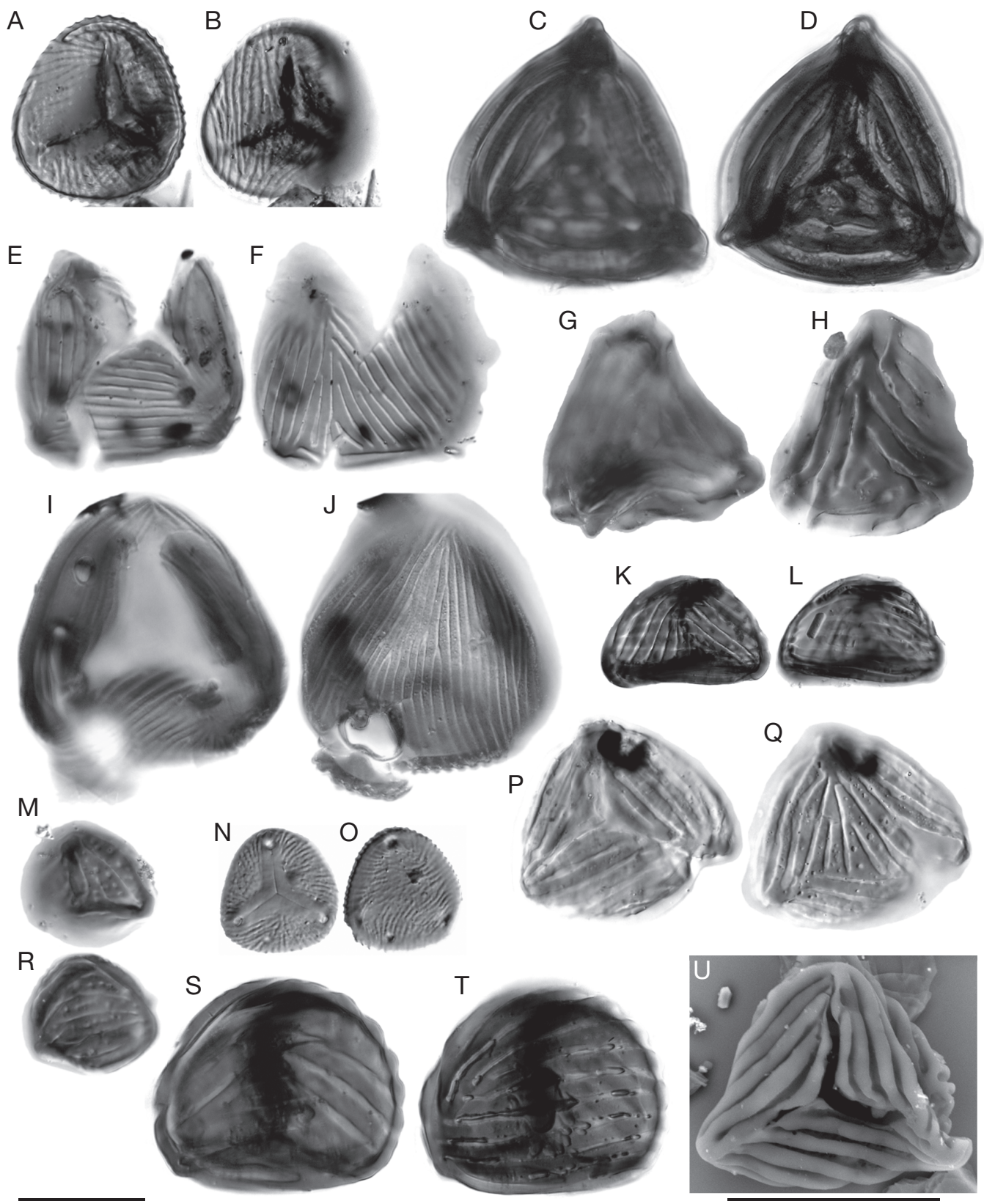

FIG. 9. - A, B, Cicatricosisporites hallei in proximal (A) and distal (B) views (FV3_3N382); C, D, Cicatricosisporites hughesii in proximal (C) and distal (D) views (FV1B2G433); E, F, Cicatricosisporites imbricatus in proximal (E) and distal (F) views (PS121R37); G, H, Cicatricosisporites sp. cf. C. imbricatus in proximal (G) and distal (H) views (PS132O343); I, J, Cicatricosisporites minutaestriatus in proximal (I) and distal (J) views (PS8bB2O532); K, L, Cicatricosisporites myrtellii in proximal (K) and distal (L) views (PS121L254); $\mathbf{M}, \mathbf{R}$, Cicatricosisporites perforatus in proximal (M) and distal (R) views (PS7c3O402); N, O, Cicatricosisporites venustus in proximal (N) and distal (O) views (PS10b3bS504); P, Q, Cicatricosisporites pseudotripartitus in proximal (I) and distal (N) views (PS10A2S383); S, T, Cicatricosisporites subrotundus in proximal (S) and distal (T) views (FV3 3_3N384); U, Cicatricosisporites pseudotripartitus in proximal view (PS10a), SEM. Scale bars: A-T, $20 \mu \mathrm{m} ; \mathrm{U}: 30 \mu \mathrm{m}$. 

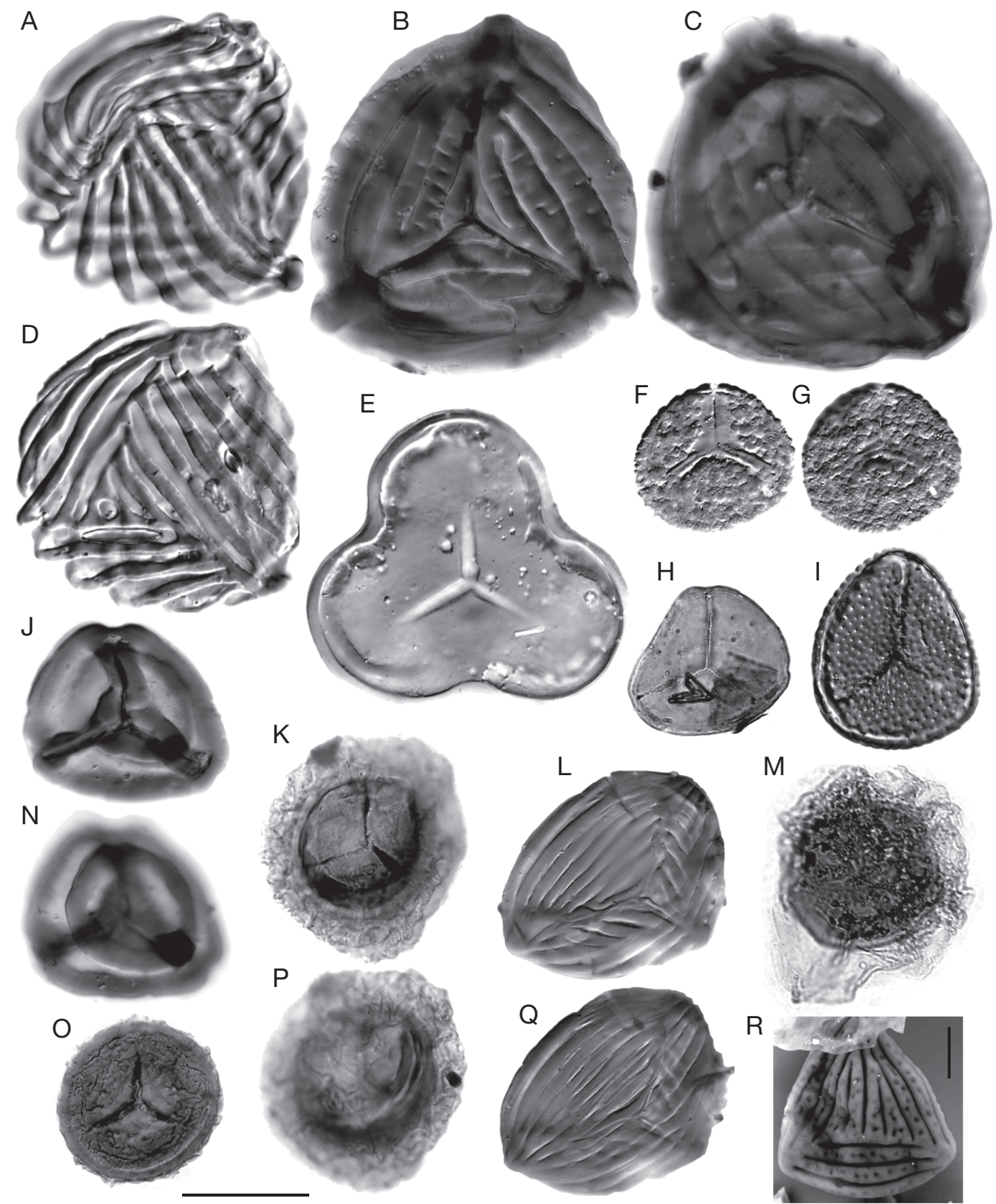

$\mathrm{R}$

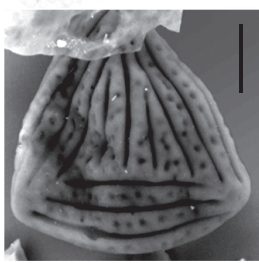

FIG. 10. - A, D, Cicatricosisporites sp. 3 in proximal (A) and distal (D) views (PS10c6U42); B, C, Cicatricosisporites sp. 4 in proximal (B) and distal (C) views (PS8bB3C37); E, Concavisporites punctatus in proximal view (PS7c30412); F, G, Converrucosisporites platyverrucosus in proximal (F) and distal (G) views (PS10a6K27); H, Deltoidospora sp. in proximal view (FV1A2H372); I, Foveosporites subtriangularis in proximal view (PS7c3X291); J, N, Coronatispora sp. in proximal (J) and distal (N) views (PS10c2N312); K, P, Gabonisporis pseudoreticulatus in proximal (K) and distal (P) views (FV2A3Z414); L, Q, Fisciniasporites brevilaesuratus in proximal (L) and distal (Q) views (PS10a3Y39); M, Crybelosporites pannuceus, high focus (VA1A2G49); O, Crybelosporites sp. in proximal view (FV2A4M402); R, Costatoperforosporites foveolatus in distal view (PS10a). Scale bars: A-Q, $20 \mu \mathrm{m} ; \mathrm{R}: 10 \mu \mathrm{m}$. 

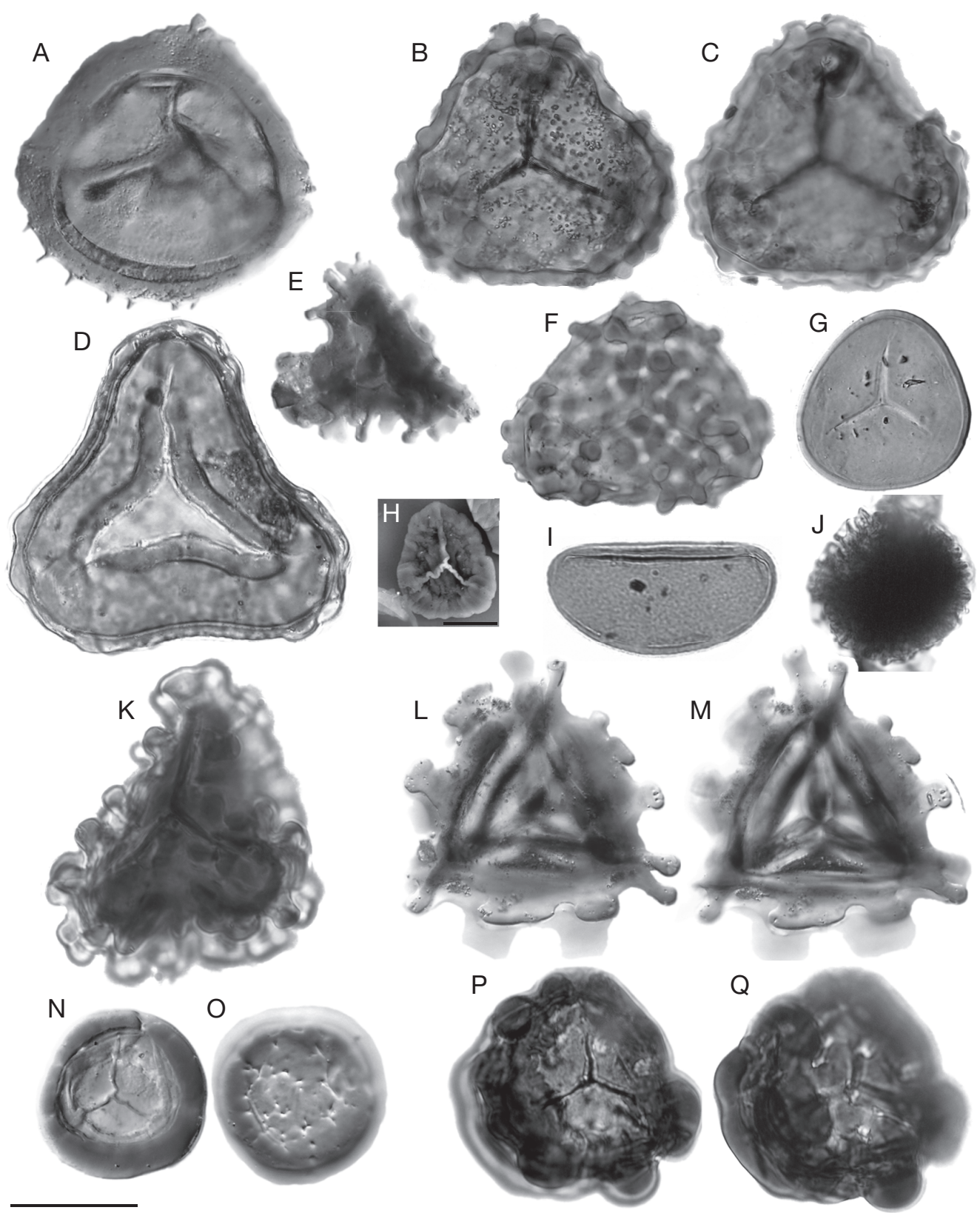

FIG. 11. - A, Heliosporites sp. in proximal view (PS122E52); B, C, Impardecispora marylandensis in proximal (B) and distal (C) views (FV4B4T33); D, Impardecispora trioreticulosa in proximal view (FV1B2O333); E, Neoraistrickia truncata in distal view (PS10b2_4F27); F, Ischyosporites disjunctus in distal view (FV4B4L491); G, Matonisporites equiexinus in proximal view (FV4A1R194); H, Patellasporites distaverrucosus in proximal view (PS10a); I, Microfoveolatosporites baconicus in lateral view (FV1A2G43); J, Gabonisporis sp., high focus (FV1A2K503); K, Neoraistrickia robusta in proximal view (FV1B2O334); L, M, Nodosisporites sp. 2 in proximal (L) and distal (M) views (PS134P38); N, O, Patellasporites sp. in proximal (N) and distal (0) views (PS10b1_4L362); P, Q, Patellasporites tavadarensis in proximal (P) and distal (Q) views (FV1A2H37). Scale bars: A-G, I-Q, $20 \mu \mathrm{m} ; \mathrm{H}, 10 \mu \mathrm{m}$. 

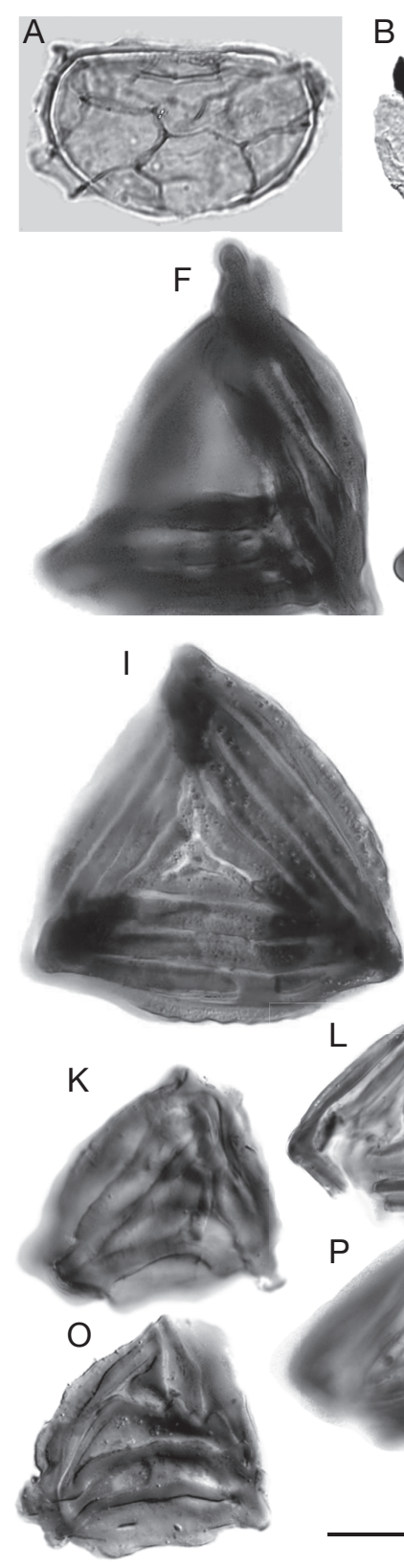

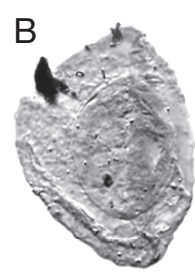

C
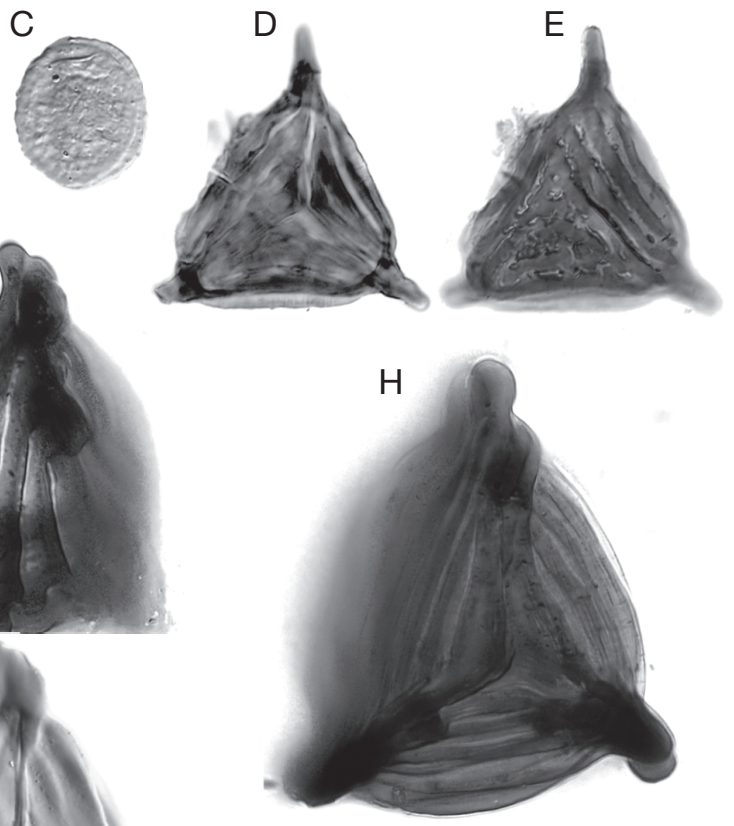

$\mathrm{J}$
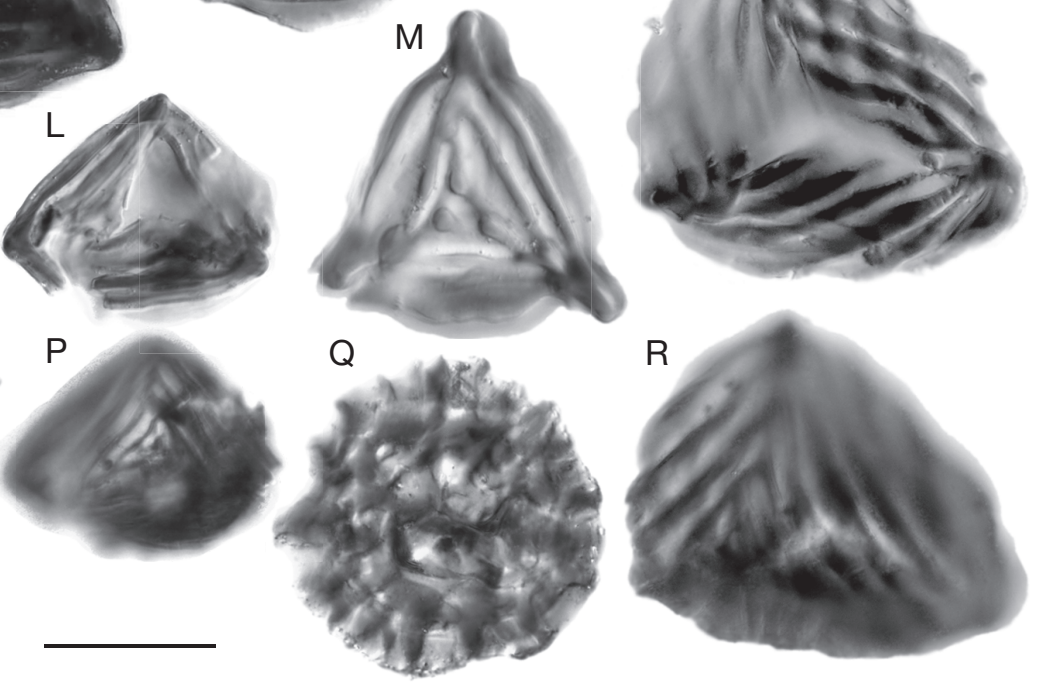

FIG. 12. - A, Perinomonoletes sp. in lateral view (FV1A2O281); B, Peromonolites fragilis in proximal view (PS121N492); C, Peromonolites sp. in distal view (PS5aA2H223); D, E, Plicatella appendicifera in proximal (D) and distal (E) views (FV4B4X432); F, G, Plicatella cristata in proximal (F) and distal (G) views (FV1B1U470); H, Plicatella bilateralis in proximal view (FV2B1K421); I, Plicatella gigantica in proximal view (PS8bB4H394); J, M, Plicatella sp. cf. P. potomacensis in proximal (J) and distal (M) views (PS10a6D30); K, O, Plicatella problematica in proximal $(\mathbf{K})$ and distal $(\mathbf{O})$ views (PS8bA3H47); $\mathbf{L}, \mathbf{P}$, Plicatella potomacensis in proximal $(\mathbf{L})$ and distal $(\mathbf{P})$ views (PS7c3X33); N, R, Plicatella triceps in proximal (N) and distal (R) views (PS8bB3D562); Q, Reticulatisporites arcuatus in distal view (PS10a3W261). Scale bar: $20 \mu \mathrm{m}$. 


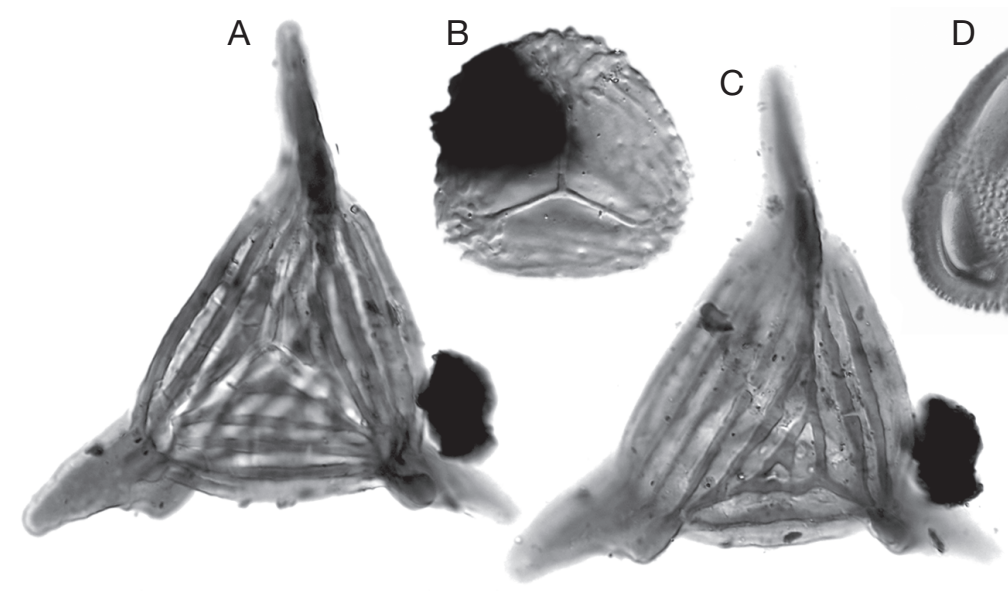

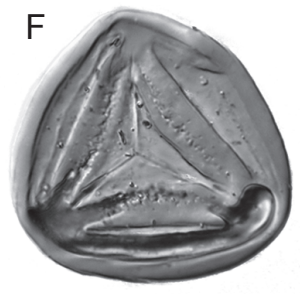

A-I
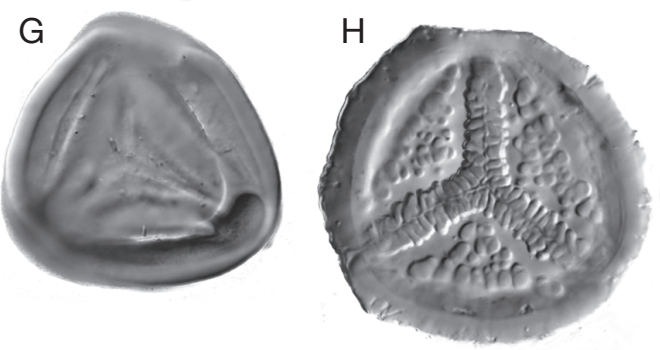
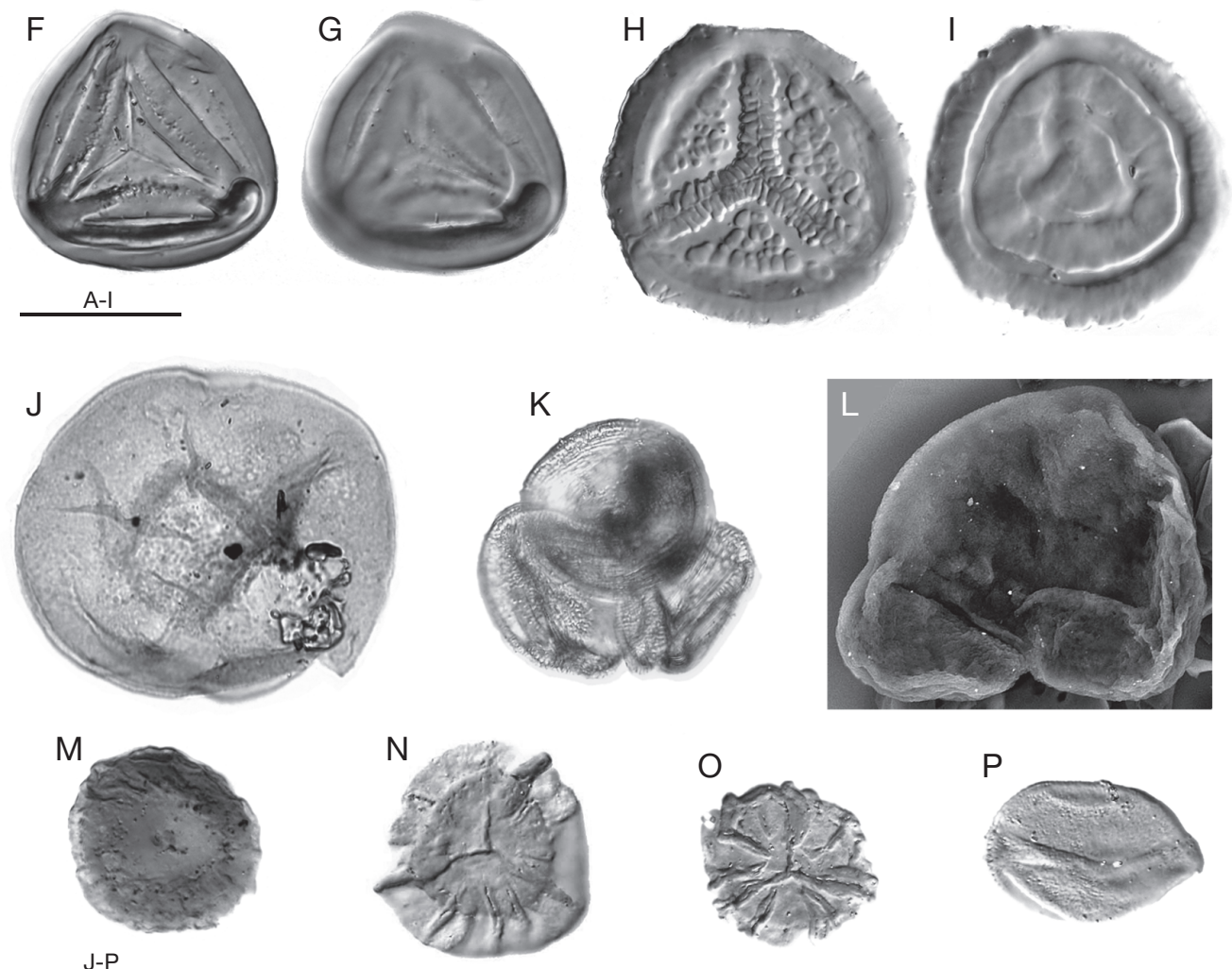

FIG. 13. - A, C, Plicatella unica in proximal (A) and distal (C) views (FV4B2P57); B, Ruffordiaspora australiensis in proximal view (PS10A2O43); D, Vadaszisporites sacalii in proximal view (PS133K543); E, Undulatisporites undulapolus in proximal view (PS10a); $\mathbf{F}$, G, Vinculisporites flexus in proximal (F) and distal (G) views (FV4 3_3R30); H, I, Taurocusporites segmentatus in proximal (H) and distal (I) views (PS8a2N28); J, Araucariacites australis, mid focus (FV1B1P404); K, Classopollis major, tetrad (PS131Q361); L, Cedripites canadensis in lateral view (PS10a); M, Applanopsis segmentatus in distal view (FV4 3 3N264); N, Applanopsis dampieri in proximal view (PS10a2H54); O, Applanopsis sp. in proximal view (PS10a3N553); P, Classopollis classoides in lateral view (PS10b1_6Q47). Scale bar: $20 \mu \mathrm{m}$. 

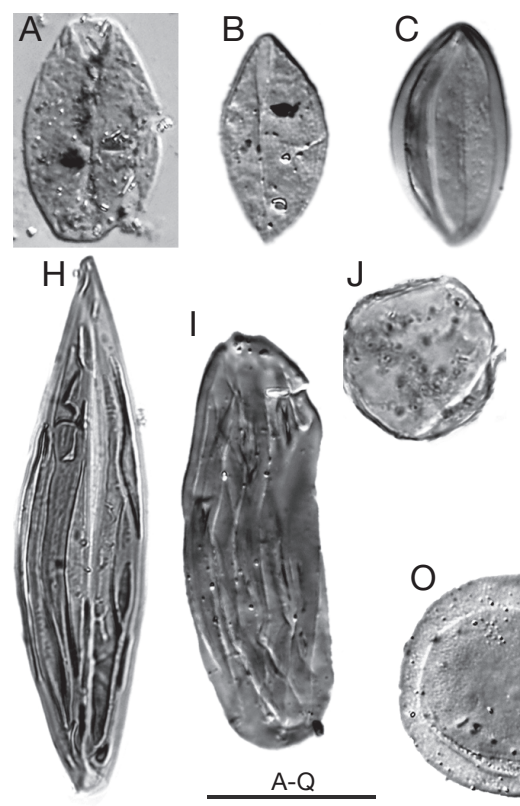

K
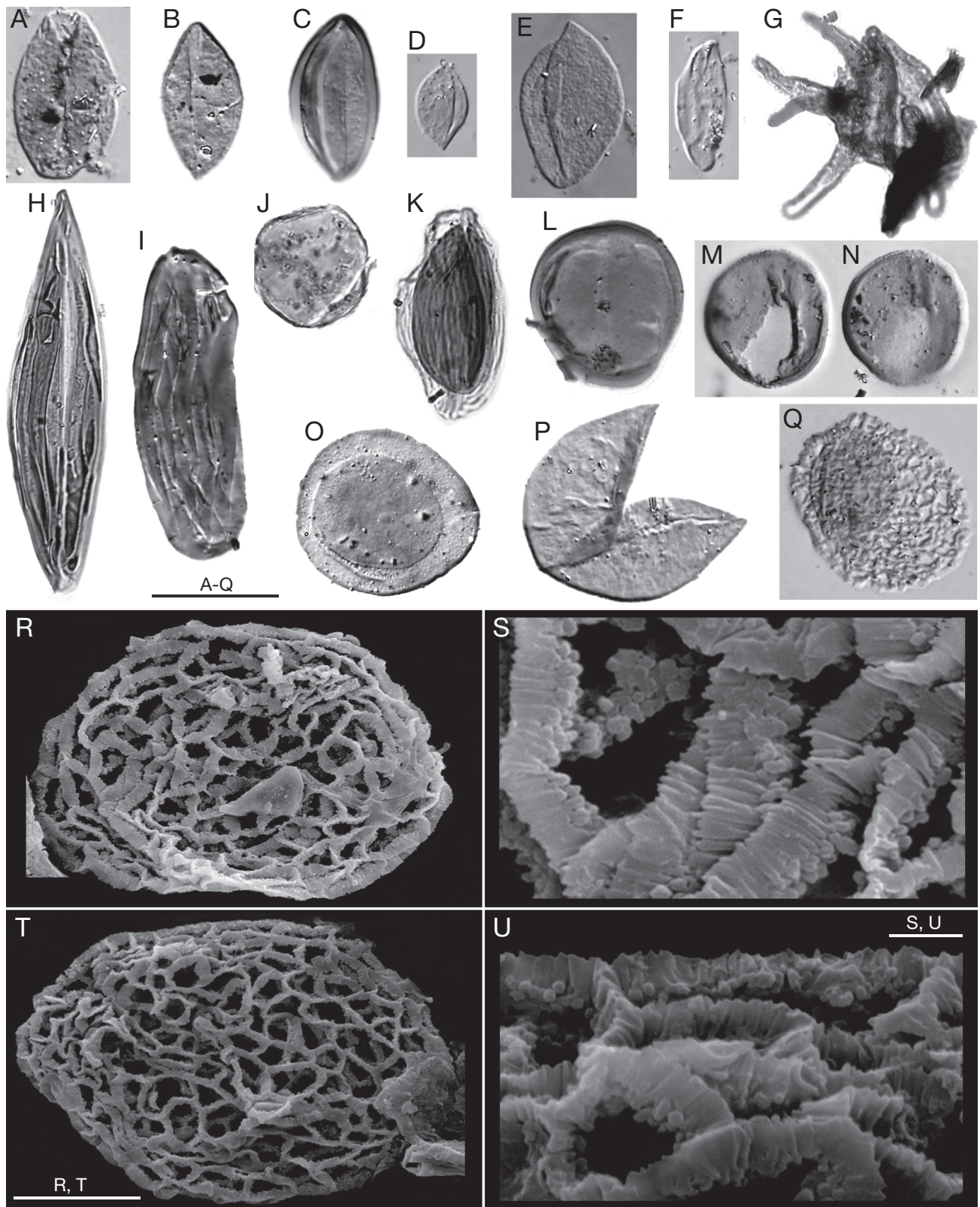

FIG. 14. - A, Cycadopites sp. 1 in proximal view (PLB02_4R42); B, Cycadopites sp. 2 in proximal view (PS10c1022); C, Cycadopites sp. 3 in proximal view (PS8bA3U322); D, Cycadopites sp. 4 in proximal view (PLB02_4B44); E, Cycadopites sp. 5 in proximal view (HCB0 6_6F282); F, Cycadopites sp. 7 in proximal view (PLB02_4O43); G, Elaterosporites klaszii in lateral view (FV3A1K484); H, Singhia acicularis in equatorial view (FV1A2H393); I, Singhia minima in equatorial view (PS126N54); J, Spheripollenites psilatus, mid focus (FV1A2S272); K, Equisetosporites ambiguus, high focus (FV1A2O444); L, Eucommiidites minor in equatorial view (FV3 3_3D291); M, N, Clavatipollenites hughesii in distal (M) and proximal (N) views (FV4G294); O, Perinopollenites halonatus, mid focus (PS10a4T45); P, Taxodiaceaepollenites hiatus in lateral view (PS122W37); Q, Afropollis jardinus, mid focus (FV4_3F29); R-U, Afropollis jardinus, SEM, mid focus; R, HCB004; S, detail of R, T (HCB005); U, detail of T. Scale bars: $\mathrm{A}-\mathrm{Q}, 20 \mu \mathrm{m} ; \mathrm{R}, \mathrm{T}, 10 \mu \mathrm{m} ; \mathrm{S}, \mathrm{U}, 1 \mu \mathrm{m}$. 

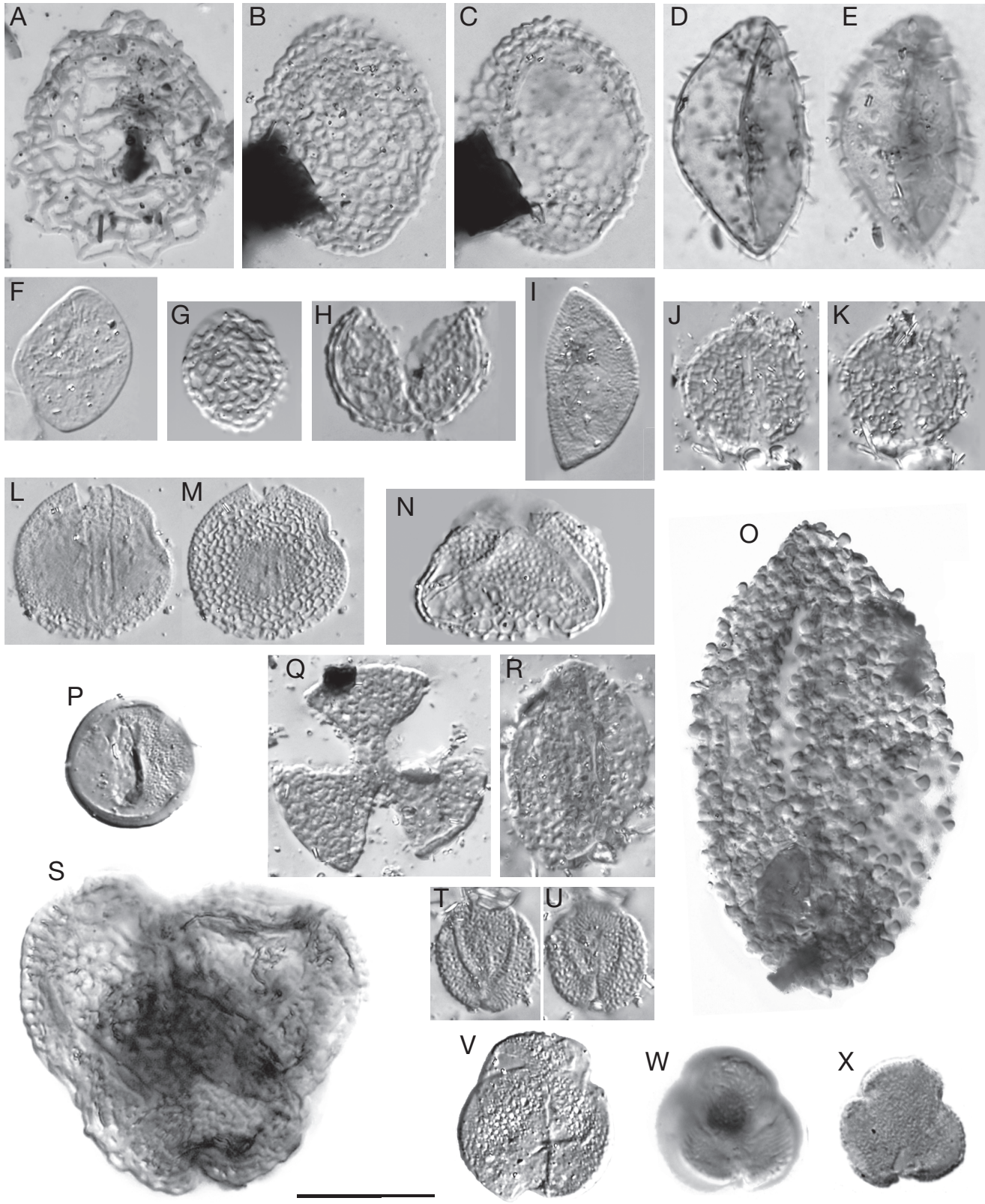

FIG. 15. - A, Dichastopollenites dunveganensis, high focus (FV1 2_3 O354); B, C, Dichastopollenites sp. cf. D. reticulatus, high (B) and mid (C) focus (FV4H31); D, E, Echimonocolpites sp., high (E) and mid (D) focus (FV4A3O253); F, Monosulcites minimus in proximal view (HCB2 3_6 L324); G, Pennipollis reticulatus in proximal view (PS122P293); H, Pennipollis sp. in lateral view (HCB2_3U30); I, Retimonocolpites fragilis in lateral view (HCB0 2_6K312); J, K, Retimonocolpites textus in distal (J) and proximal (K) views (PLB02_4R383); L-N, Similipollis sp. in distal (L) and proximal (M) views (PLB02_4K3); N, high focus (PS11b4R292); O, Stellatopollis barghoornii in distal view (FV4W271); P, Transitoripollis sp. cf. T. similis in distal view (PS11a1S551); Q, R, Rousea brenneri; Q, polar view (PLB02_4O332); $\mathbf{R}$, equatorial view (PLB02 4T39); S, Senectotetradites varireticulatus, tetrad (FV3 3 3 T282); T, U, Rousea georgiensis in polar view (PLB02_4K544); T, high focus; U, low focus; V, Rousea sp. B in Burger 1993 in polar view (PS126V372); W, Striatopollis paraneus in polar view (FV4 3_3V334); X, Tricolpites blechrus in polar view (FV1_2D43). Scale bar: $20 \mu \mathrm{m}$. 
most Albian sea-level rise is contemporary with the dispersion of parent plants producing the spores and pollen grains across the Tethys from Northern Gondwana to Southern Laurasia and vice versa. Although rising sea level tended to inhibit rather than permit dispersal of terrestrial plants, it would be associated with a climatic change that may have favoured their dispersal in freshwater habitats into lowland fluvial-deltaic environments.

In the area of study, the Boundary Marls Unit is characterized by a peak of abundance of Gondwanan elements such as Elaterosporites klaszii, Afropollis jardinus, Gnetaceaepollenites barghoornii, Ephedripites spp. and Stellatopollis barghoornii from the Tethyan realm. The penetration of Northern Gondwanan elements into Southern Laurasia is in agreement with the view of Batten \& Li (1987), Herngreen \& Dueñas Jiménez (1990) and, Pactlová \& Lashin $(1998,1999)$ that the geographic extent of the floral province characterised by elater-bearing species was much greater than originally estimated. It is also supported by the presence in the present work of the typically Laurasian form Dichastopollenites reticulatus, also found in Northern Gondwana at the same time interval. This indicates a transitional area between Northern Gondwana and Southern Laurasian floral belts that has been already reported by other authors in France, Portugal and the Southern Alps (Hochuli 1981). Based on the presence of Afropollis and other Gondwanan taxa, Hochuli (1981) suggested a climatic change as the cause for the northward extension of the Northern Gondwana floral belt during the late Albian-Cenomanian.

For better understanding of the palaeogeographical setting during the late Albian-early Cenomanian in terms of admixture of microfloras from adjacent areas, some selected taxa (Afropollis jardinus, Asbeckiasporites, Elaterosporites klaszii, Penetetrapites mollis, Stellatopollis barghoornii, Vadaszisporites sacalii and Cyclonephelium chabaca) have been plotted (Figs 4-6) on reconstruction of continental areas for this time interval.

The first undoubtful appearance of the genus Afropollis has been reported from the late Barremian both in Northern Gondwana (Egypt) and Southern Laurasia Provinces (England) represented by cryptaperturate forms (Penny 1989). It disappeared possibly in the middle Cenomanian in Gondwana (Doyle et al. 1982) and in the late Cenomanian in Laurasia (Doyle et al. 1982; Penny 1989, 1991; Schrank \& Nesterova 1993). Highest frequencies of the genus Afropollis are observed toward the supposed paleoequator between $15^{\circ} \mathrm{N}$ and $S$ (northeast Brazil, Peru, Senegal, Ivory Coast, Mali, Egypt), decreasing to the south (Gabon, Congo, Angola, 15-20 $\mathrm{S}$ ) and to the north (Northern Africa: Morocco, Algeria; southern Alps, $15-20^{\circ} \mathrm{N}$ ) (Doyle et al. 1982).

On the one hand, in Gondwana, the genus Afropollis appeared probably in Gabon at the same time (late Barremian) as in Egypt and England based on the Elf-Aquitaine correlation of the relevant zone (C-VII), represented by zonasulculate forms ( $A$. operculatus, $A$. zonatus, $A$. aff. zonatus), being zone C-VII older than previously thought (Doyle 1992). Gabon record is also in line with Brazil, being Barremian rather than Aptian the interval containing the first Afropollis (Regali \& Viana 1989). After a first maximum of Afropollis during the late Barremian, this genus became rarer in the late Aptianearly Albian, where zonasulculates were replaced by strongly heteropolar inaperturates ( $A$. aff. jardinus). However, it reached a second maximum during the early-middle Albian in Northern Gondwana, AfricaSouth America (Fig. 7), with the almost isopolar, inaperturate species $A$. jardinus. It declined again during the latest Albian-early Cenomanian and dissappeared during the (middle?) Cenomanian (Doyle et al. 1982).

On the other hand, it is noteworthy that all the reports of the genus Afropollis in the southern Laurasia (Fig. 4) are from the Tethyan-North AtlanticGulf Coastal fringe of Laurasia: England, France, Italy, Portugal and Spain in Europe, and also from Canada (Nova Scotia) and USA (Maryland and Oklahoma) (Hasenboehler 1981; Doyle et al. 1982; Penny 1989; Fiet \& Pons 1998; De la Fuente et al. 2007; Villanueva-Amadoz 2009; Denise Pons, unpublished observations). Its presence coincides with two main rare extensions of northern Gondwanan elements across the Tethys into southern Laurasia (Doyle et al. 1982). The first one corresponds the occurrence of the species $A$. zonatus in the early Aptian from the Breggia River section of southern Switzerland and the Cismon section of northern 

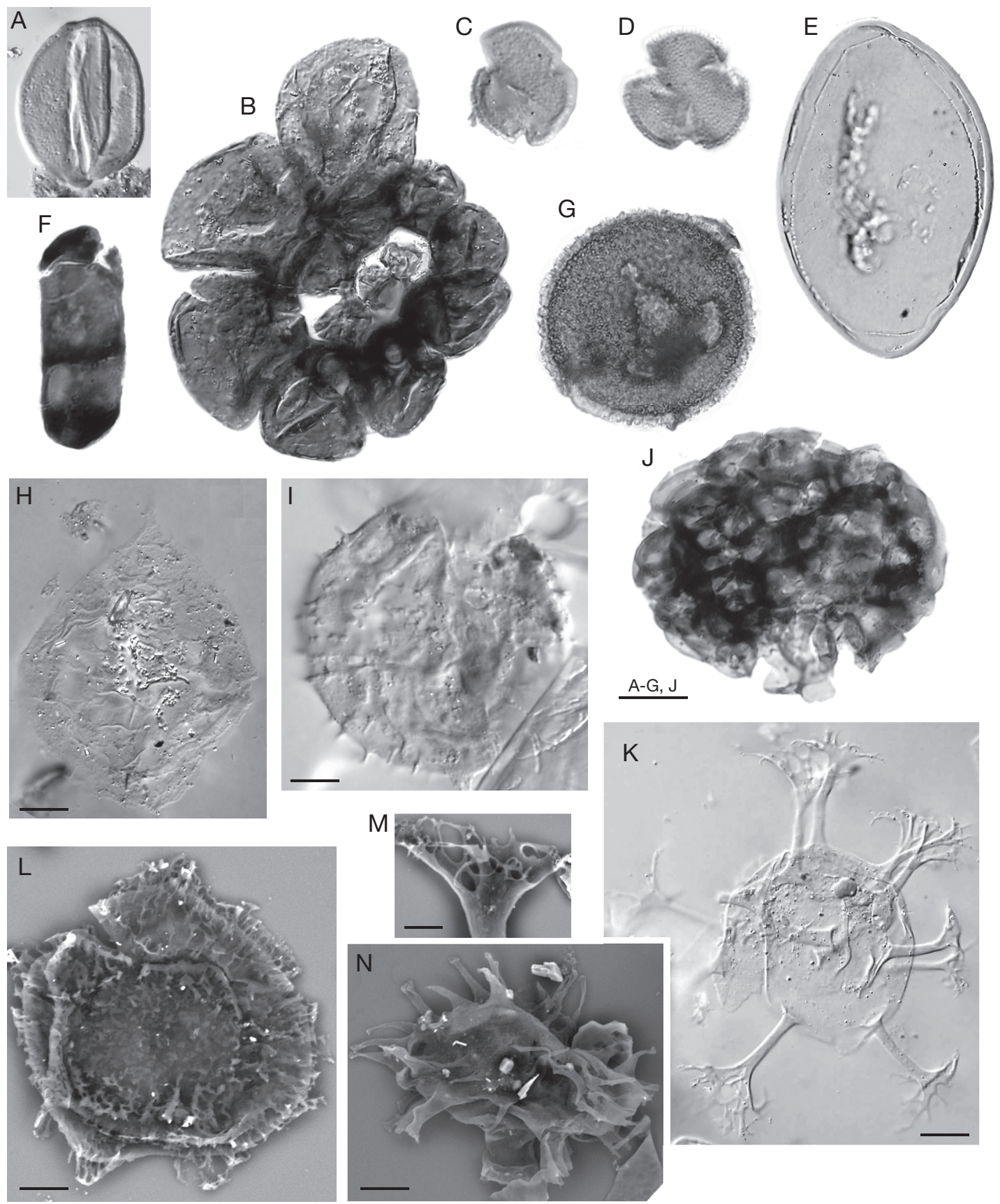

FIG. 16. - A, Tricolpites crassimurus in equatorial view (HCB0_2J45); B, Foraminiferal lining (PS131V513); C, aff. Tricolpites crassimurus in polar view (FV4A3H32); D, aff. Tricolpites crassimurus in polar view (FV2A4N294); E, Schizophacus spriggi in equatorial view (HUIIB1W43); F, Dicaellaesporites sp. (FV1A2S224); G, Schizosporis microreticulatus, mid focus (FV1A2H384); H, Sublitisphaera sp. (HCB0 2 6J32); I, Cribroperidinium sp. (PS8bB2W35); J, Plochmopeltinites sp. (FV2A1M221); K, M, Oligosphaeridium pulcherrimum; K, PS8bB2M544; M, SEM (PS10a); L, Cyclonephelium chabaca, SEM (PS10a); N, Florentinia sp., SEM (PS10a). Scale bars: $\mathrm{A}, \mathrm{C}, \mathrm{D}, 10 \mu \mathrm{m} ; \mathrm{B}, \mathrm{E}-\mathrm{N}, 7 \mu \mathrm{m}$. 
Italy (Hochuli 1981), and also by $A$. operculatus and $A$. zonatus from the DSDP sites 417D, 418A, and $418 \mathrm{~B}$, located near the latitude of Rio de Oro of the North Atlantic (Hochuli \& Kelts 1980). The presence of these species has been correlated with Zone C-VII in Gabon by Doyle et al. (1977). The peak of abundance of Afropollis jardinus in the late Albian-early Cenomanian in the present work (Fig. 7) is coincident with the second main peak reported by Doyle et al. (1982). This taxon, associated with Elaterosporites klaszii, Elateroplicites africaensis, and Elaterocolpites castelainii, has been reported from Breggia River and Cismon sections in the Southern Alps (Hochuli 1981) and also from the North Atlantic (Hochuli \& Kelts 1980). Afropollis jardinus has also been reported, with a maximum of $2-5 \%$ of the total palynological content, from the late Albian in Portugal (Hasenboehler 1981). This second peak seems to correspond with the third Albian peak (Fig. 7) reported from the "marnes à Fucoïdes" Formation in Marches-Ombrie (Italy), also associated with the first appearance of Elaterocolpites castelainii (Fiet \& Pons 1998; Fiet 1999). The latter formation has been dated as latest Albian (Vraconian) within stratigraphic zone I4 including the foraminiferal biozone Praeglobotruncana buxtorfi and ammonite biozone Stoliczkaia dispar. Another peak of Northern Gondwanan elements (elaterates, Afropollis, Cretacaeiporites, etc.) in Laurasia, possibly different from that described in the present work (Fig. 7), has been reported from the fluvial and estuarine successions of the Peruc-Korycany Formation of the Bohemian mid-Cenomanian (Afropollis jukesbrownei Zone) (Pactlová \& Lashin $1998,1999)$, which coincides with the initial transgression during the Cenomanian.

The presence of this taxon in the two most complete reference sections with Afropollis in Gondwana (Fig. 7) appears to be slightly earlier than or diachronous relative to the late Albian deposits in the study area and other southern Laurasian areas. It corresponds to Palynozones VIII to X (late Albian-early Cenomanian) from Senegal and to Palynozones C-X to C-XIIa (early-middle Albian) corresponding to Madièla Formation from the eastern Basin of North Gabon (Doyle et al. 1982). High values of Afropollis jardinus from other Gondwanan sections could also be correlated with the Gabon zonation: deposits from Angola and southeastern Brazil (Zone PC42, Riachuelo Formation) are correlated with Subzone C-XIIa, northeastern Brazil with Zones C-IX to C-XI (Zones IA and IB, Itapecuru and Tutoiá Formations), Ivory Coast/Ghana with Subzones C-XIIa to C-XIIb and Algeria with Zones C-IX or C-X to C-XIIb (Doyle et al. 1982). However, the age of the deposits (especially from wells) in northern Gondwana need revision as there are some imprecisions in faunal dating. Moreover, some successions are based on composite sections (i.e. Senegal reference section).

Elaterosporites klaszii is more abundant in coastal environments between palaeolatitudes of $15^{\circ} \mathrm{N}$ and $15^{\circ} \mathrm{S}$; however, exceptionally it is also present $5^{\circ}$ northwards and southwards during the AlbianCenomanian (Fig. 5).

The typically Tethyan taxa Stellatopollis barghoornii and Penetetrapites mollis are more frequent between palaeolatitudes of $40^{\circ} \mathrm{N}$ and $20^{\circ} \mathrm{S}$ (Fig. 6).

Another Tethyan taxon, Cyclonephelium chabaca (Fig. 4), is also present in the association. It is a specialized tropical-subtropical species, which has palaeolatitudinal ranges between $25^{\circ} / 30^{\circ} \mathrm{N}$ and $40^{\circ} S$ (Masure \& Vrielynck 2009). The high abundance of the dinocyst assemblage at level PS 13, mainly dominated by the single species $C y$ clonephelium chabaca, could reflect an algal bloom event in response to the mid-Cretaceous marine transgression under lagoonal or other limited marine circulation paleoenvironments. This event has been previously reported by Nelson (2008) for the Albian-Cenomanian nearshore deposits (Vermelha and Pinda formations) from the offshore of Cabinda in Angola.

Furthermore, the presence in this work of typical microfloral elements known from the Carpathian Mountains, Moessic platform and Donetz Basin, represented by the genera Asbeckiasporites, Matonisporites, Vadaszisporites and Vinculisporites (Fig. 5), suggests a boreal origin. The appearance of Asbeckiasporites at the Damodar Basin in India (Vijaya 2011), not figured in the paper, constitutes the southernmost reported occurrence of this genus to date. It could correspond to a transported element or endemic species due to the restriction of other boreal 
taxa to palaeolatitudes between $20-45^{\circ} \mathrm{N}$. However, India was much farther south at this time as seen in Figure 5. Such taxa have also been observed in the late Albian in Marches-Ombrie Basin in Italy by Fiet (1999) and Fiet \& Pons (1998) who interpreted its presence as a result of transport by the north-Tethyan marine currents oriented NE-SW (Francis \& Frakes 1993). However, the possibility is more acceptable that the mid-Cretaceous transgression together with a climatic change, would have favoured an expansion of the Tethyan areas that were subjected to equivalent environmental conditions.

\section{PALAEOCLIMATICAL AND PALEOECOLOGICAL IMPLICATIONS}

The climatic conditions at the palaeolatitude of $25^{\circ} \mathrm{N}$ of the Iberian Plate changed from a warm humid climate during the Aptian (Gröcke 2002) to a more arid climate during the late Albian. The high proportion of Classopollis (from PS 6 to PS 10), together with the presence of the species Gnetaceaepollenites barghoornii, Elaterosporites klaszii and some types of Ephedripites in the deposits of the Boundary Marls Unit and Mosqueruela Formation, may indicate more arid conditions than in the underlying Escucha Formation, which shows higher percentages of fern spores with high abundance and diversity of Schizaeaceae. However, although aridity increases, we observe a high percentage of Afropollis, possibly related to humid tropical climates (Doyle et al. 1982), and lycopod spores, which indicate locally wet conditions in the studied sections.

The highest values of Afropollis jardinus (Table 1 ), reaching in some levels the $43 \%$ of the total palynological assemblage at FV-4 and $99 \%$ at HUB0 (the latter of the total 1520 palynomorphs), are coincident with very low values of dinoflagellate cysts (0.1-2.6\%) and the genus Classopollis $(\leq 1.5 \%)$. The correlation of high percentages of the genus Afropollis with coastal lacustrine environments with low marine influence has also been reported from Gabon (maximum $6 \%$ of the total palynomorph assemblage in the lower Aptian Cocobeach Forma- tion in Doyle et al. 1990) and Brazil [maximum $40 \%$ in the lower Albian from Maranhão Basin (Müller 1966) and maximum $50 \%$ in the Crato Formation from Araripe Basin (Pons et al. 1996), late Aptian in age (Heimhofer \& Hochuli 2010). Hochuli (1981) noted the possibility that the recovered Gondwanan taxa including Afropollis jardinus had undergone long-distance transport before their deposition and thus, reflect the latitudinal position of their area of origin. Later, Doyle et al. (1982) mentioned the possibility that the presence of Afropollis in Laurasian palynofloras might be the result of long-distance wind transport of pollen across the Tethys. However, this work shows that the abundance of the species Afropollis jardinus is variable, suggesting a facies control. The markedly high abundances of this species at HU-B0, its good preservation, the numerous tetrads (also preserved in clumps) and their presence restricted to lacustrine facies supports a short-distance transport prior their deposition.

Marine influence is also indicated by low percentages of the total palynomorph assemblage of foraminiferal linings (about $0.3 \%$ ) and dinoflagellate cysts (0.1-21.8\% except for sample PS-7 with a $48 \%$ ). The presence of the prasinophycean alga Pterospermella aristotelesii in samples PS-6, PS-11, FV-3, HU-II and HU-B1 is concordant with the marine influence, which occurs in brackish or estuarine settings (Brocke \& Riegel 1996; Prauss 2001).

\section{CONCLUSIONS}

A latest Albian-earliest Cenomanian age has been established for the Boundary Marls Unit in the Aliaga and Oliete Sub-basins in northeastern Spain.

These palaeogeographical data improve our knowledge of the mid-Cretaceous phytogeographical provinces and their distribution through time. At this time the studied area was located within a transitional floristic belt between southern Laurasian to the northern Gondwana provinces under a humid climate. Moreover, boreal elements are also represented by Asbeckiasporites, Matonisporites, Vadaszisporites and Vinculisporites. 
The worldwide late Albian marine transgressions, together with the opening of the Tethys and the Atlantic Ocean, favoured the northward extension of some typically Gondwanan elements such as Afropollis jardinus, Crybelosporites pannuceus, Elaterosporites klaszii, Gabonisporis spp., Stellatopollis barghoornii and some types of Ephedripites.

Data from these sections show that Afropollis jardinus appeared in high abundance in the late Albian in the Maestrat Basin coinciding with the appearance of Elaterosporites klaszii and the second main maximum abundance of the genus Afropollis. It seems that Afropollis jardinus occurred in high percentages in coastal lacustrine or lagoon environments. However, it is noteworthy that Afropollis jardinus is absent in the Escucha Formation, with its presence restricted to the overlying Utrillas Formation, Boundary Marls Unit and the base of the Mosqueruela Formation.

\section{Acknowledgements}

This study was supported by the Spanish Project CGL2008-00809/BTE, Mexican Project CONACYT 104515 and a fellowship award to U.V.A. funded by the Gobierno de Navarra. The authors thank the Caja de Ahorros de la Inmaculada (CAI) for research travel grants and the Aragón Government for field grants. The authors also wish to express their gratitude to the Paleobotanist Group of Centre de Recherche en Paléobiodiversité et Paléoenvironnements for providing logistic assistance and access to optical microscopy equipment (UMR 7207-UPMC-CNRS-MNHN) and Suso Méndez from the CACTI (University of Vigo) for his help in getting the electron microscopic images. We are also grateful to James A. Doyle and David J. Batten for suggestions and substantial improvements in the manuscript.

\section{REFERENCES}

Abubakar M. B., Obaje N. G., Luterbacher H. P., Dike E. F. C. \& Ashraf A. R. 2006. - A report on the occurrence of Albian-Cenomanian elater-bearing pollen in Nasara-1 well, Upper Benue Trough, Nigeria: biostratigraphic and palaeoclimatological implications.
Journal of African Earth Sciences 45: 347-354.

Aguilar M., Ramírez del Pozo J. \& Riba O. 1971. Algunas precisiones sobre la sedimentación y paleontología del Cretácico inferior en la zona de Utrillas-Villarroya de los Pinares. Estudios Geológicos 27: 497-512.

Allix P. 1982. - Environnements mésozoïques de la partie nord-orientale du fossé de la Bénoué (Nigéria). Stratigraphie, sédimentologie, évolution géodynamique. Thèse $3^{\mathrm{e}}$ Cycle, Université Aix-Marseille, 145 p. (unpublished).

Allix P. 1983. - Environnements mésozoïques de la partie nord-orientale du fossé de la Bénoué (Nigéria). Stratigraphie-sédimentologie-évolution géodynamique. Travaux Laboratoires des Sciences de la Terre, St Jérôme Marseille, série B 21: 1-200.

ARAI M. 2005. - Biodiversité des Dinoflagellés de la marge brésilienne de l'Atlantique central et de l'Atlantique sud: outil traceur des échanges entre l'Atlantique nord et l'Atlantique sud au Crétacé moyen et supérieur. Diplôme d'études supérieures, Université Pierre et Marie Curie, Paris, 93 p. (unpublished).

AtaWy S. A. M. 2009. - Palynological investigation of some rock units from Paleozoic-Mesozoic of the Sheiba-1 well, Western Desert, Egypt. Journal of Applied Sciences Research 5: 122-136.

atta-Peters D. \& Salami M. B. 2006. - AptianMaastrichtian palynomorphs from the offshore Tano Basin, western Ghana. Review of Palaeobotany and Palynology 46: 379-394.

AWAD M. Z. 1994. - Stratigraphic, palynological and paleoecological studies in the East-Central Sudan (Khartoum and Kosti basins), Late Jurassic to midTertiary. Berliner geowissenschaftliche Abhandlungen A 161: 1-163.

AzÉma C. \& Ters M. 1971. — Étude palynologique préliminaire du gisement cénomanien de la Bironnière, Vendée (France). Review of Palaeobotany and Palynology 11: 267-282.

Azéma C., Durand S. \& Médus J. 1972. — Des miospores du Cénomanien moyen. Paléobiologie continentale 3 (4): 1-54.

Barron E., Comas-Rengifo M.J. \& Elorza, L. 2001. Contribuciones al estudio palinológico del Cretácico Inferior de la Cuenca Vasco-Cantábrica: Los afloramientos ambarígenos de Peńacerrada (España). Coloquios de Paleontología 52: 135-156.

Batten D. J. \& Li W.-B. 1987. - Aspects of palynomorph distribution, floral provinces and climate during the Cretaceous. Geologisches Jahrbuch, Reihe A 96: 219-237.

BELOW R. 1981. - Dinoflagellaten-Zysten aus dem oberen Hauterive bis unteren Cenoman Süd-WestMarokkos. Palaeontographica B 176: 1-145.

Below R. 1984. - Aptian to Cenomanian dinoflagellate cysts from the Mazagan Plateau, northwest Af- 
rica (Sites 545 and 547, Deep Sea Drilling Project Leg 79). Initial Reports of Deep Sea Drilling Project 79: 621-649.

Belsky C. Y., Jardiné S., Prestat B., Durif P., GrosdiDiER E., CASSAN J. P. \& Gillmann M. 1975. —Étude stratigraphique d'une coupe du Crétacé-Tertiaire au large du Suriname. Proceedings of the 9th International Guyana Geological Conference. Boletin de Geologia Venezuela: 179-197.

Bercovici A., Hadley A. \& Villanueva-Amadoz U. 2009. - Improving depth of field resolution for palynological photomicrography. Palaeontologia Electronica 12 (2): 1-12.

BetTAR I. \& MÉon H. 2001. - Étude palynologique du passage Albien moyen-Albien supérieur du Bassin de Tarfaya (sud-ouest du Maroc) et nouvelles données sur la province afro-sudaméricaine. Revue de Micropaléontologie 44: 107-123.

BetTAR I. \& MÉON H. 2006. - La palynoflore continentale de l'Albien du bassin d'Agadir-Essaouira (Maroc). Revue de Paléobiologie 25: 593-631.

Biens P. \& MAGLoIRE L. 1965. - Rapports internes S. N. R. E. P. A. L., Algérie (unpublished).

BiNT A. N. 1986. - Fossil Ceratiaceae: a restudy and new taxa from the mid-Cretaceous of the Western Interior, USA. Palynology 10: 135-180.

Boer N. P. DE, VAn DER Hammen T. H. \& Wymnstra T. A. 1965. - A palynological study on the age of some borehole samples from the Amazonas Delta Area, NW Brazil. Geologie en Mijnbouw 44: 254-258.

BolkHOVITINA N. A. 1966. - The fossil spores of the ferns of the family Gleicheniaceae (taxonomy and distribution), in NeISHTADT M.I. (ed.), [The Importance of Palynological Analysis for Stratigraphic and Palaeofloristic Investigations]. Nauka, Moscow: 65-75 (in Russian).

BOLTENHAGEN E. 1965. - Introduction à la palynologie stratigraphique du bassin sedimentaire de 1'Afrique équatoriale. Mémoire du BRGM 32: 305-326.

BOLTENHAGEN E. \& SALARD-CHEBOLDAEFF M. 1987. Étude palynologique du sel Aptien du Congo. Mémoires et Travaux de l'Institut de Montpellier 17: 273-293.

BRAMAN D. R. 2001. - Terrestrial palynomorphs of the Upper Santonian-?lowest Campanian Milk River Formation, southern Alberta, Canada. Palynology 25: 57-107.

Brenner G. J. 1968. — Middle Cretaceous spores and pollen from northeastern Peru. Pollen et Spores 10: 341-383.

BrenNer G. J. 1976. — Middle Cretaceous floral provinces and early migration of angiosperms, in BECK C. B. (ed.), Origin and Early Evolution of Angiosperms. Columbia University Press, New York: 23-44.

Brocke R. \& Riegel W. 1996. - Phytoplankton responses to shoreline fluctuations in the Upper Muschelkalk (Middle Triassic) of Lower Saxony (Ger- many). Neues Jahrbuch für Geologie und Paläontologie - Abhandlungen 200: 53-73.

Brown C. W. \& PierCe R. L. 1962. - Palynologic correlations in Cretaceous Eagle Ford Group, northeast Texas. Bulletin of the American Association of Petroleum Geologists 46: 2133-2147.

Burger D. 1993. - Early and middle Cretaceous angiosperm pollen grains from Australia. Review of Palaeobotany and Palynology 78: 183-234.

Calonge A. 1989. - Bioestratigrafía del Cenomaniense de la Cordillera Ibérica por Foraminiferos bentónicos. $\mathrm{PhD}$ dissertation, Universidad Complutense de Madrid, 535 p. (unpublished).

Campos D. A., Santos M. E. C. M., Carvalho M. S. S. \& Lima M. R. 1994. - The Parnaíba Basin, in Beurlen G., Campos D. A. \& Viviers M. C. (eds), Stratigraphic Range of Cretaceous Mega- and Microfossils of Brazil. IGEO/Universidade Federal do Rio de Janeiro, Brazil: 371-391.

Canérot J., Cugny P., Pardo G., Salas R. \& Villena J. 1982. - Ibérica central-Maestrazgo, in GARCIA A. (ed.), El Cretácico de España. Universidad Complutense, Madrid: 273-344.

CarvalHo M.A. 2001. - Paleoenvironmental Reconstruction Based on Palynological and Palynofacies Analyses of the Aptian-Albian Succession in the Sergipe Basin, Northeastern Brazil. Thesis Ruprecht-Karls Universität, Heidelberg, 160 p. (unpublished).

Clarke R. F. A. \& Verdier J. P. 1967. - An investigation of microplankton assemblages from the Chalk of the Isle of Wight, England. Verhandelingen der Koninklijke Nederlandsche Akademie van Wetenschappen, Afd. Natuurkunde 24 (3): 1-96.

DAVEY R. J. 1978. - Marine Cretaceous palynology of Site 361, DSDP Leg 40, off southwestern Africa, in Bolli H. M., Ryan W. B. F., McKnight B. K., Kagami H., Melguen M., Siesser W. G., Longoria J. F., Decima F. P., Foresman J. B., Hottman W. E. \& Natland J. H. (eds), Cape Town, South Africa to Abidjan, Ivory Coast, December 1974-February 1975. Initial Reports of the Deep Sea Drilling Project 40: 883-913.

DeÁK M. H. \& Combaz A. 1967. — «Microfossiles organiques" du Wealdien et du Cénomanien dans un sondage de Charente-Maritime. Revue de Micropaléontologie 10 (2): 69-96.

DE BALDIS E. D. P. 1995. - Santonian microflora of Rio Guanaco Formation (continental facies) from Rio Turbio profile, Santa Cruz province, Argentine. Southern hemisphere correlation. SAMC News 2: 20.

DejAX J. \& MASURE E. 2005. - Analyse palynologique de l'argile lignitifère à ambre de l'Albien terminal d'Archingeay (Charente-Maritime, France). Comptes Rendus Palevol 4: 53-65.

de la Fuente M., Zetter R., Martín-Closas C. \& Gomez B. 2007. - Late Barremian delta plain 
vegetation beyond cheirolepidiaceous swamps (Uña, SW Iberian Ranges, Spain): a palynological approach. 7th European Palaeobotany \& Palynology Conference, Prague - Abstracts: 29.

Dino R. 1992. - Palinologia, bioestratigrafía e paleoecologia da Formação Alagamar - Cretáçeo da Bacia Potiguar, nordeste do Brasil. PhD dissertation, Universidade de São Paulo, Instituto de Geociências, 299 p. (unpublished).

Dino R., Pocknall D.T. \& Dettmann M.E. 1999. Morphology and ultrastructure of elater-bearing pollen from the Albian to Cenomanian of Brazil and Ecuador: implications for botanical affinity. Review of Palaeobotany and Palynology 105: 201-235.

Doukaga (Moussavou) A. 1980. - Étude palynoplanctologique dans le Crétacé inférieur et moyen du bassin sédimentaire du Gabon. Thèse 3e Cycle, Université des Sciences et Techniques de Lille, $n^{\circ} 823$, 174 p. (unpublished).

DOYLE J. A. 1992. - Revised palynological correlations of the lower Potomac Group (USA) and the Cocobeach sequence of Gabon (Barremian-Aptian). Cretaceous Research 13: 337-349.

DoYle J. A. 2000. — Paleobotany, relationships, and geographic history of Winteraceae. Annals of the Missouri Botanical Garden 87: 303-316.

DoYLE J. A. \& RobBins N. I. 1977. — Angiosperm pollen zonation of the continental Cretaceous of the Atlantic Coastal Plain and its application to deep wells in the Salisbury embayment. Palynology 1: 43-78.

DOYLE J. A., VAN CAMPO M. \& LUGARDON B. 1975. Observations on exine structure of Eucommiidites and Lower Cretaceous angiosperm pollen. Pollen et Spores 17: 429-486.

Doyle J. A., Biens P., Doerenkamp A. \& Jardiné $S$. 1977. - Angiosperm pollen from the pre-Albian Lower Cretaceous of Equatorial Africa. Bulletin des Centres de Recherche Exploration-Production Elf Aquitaine 1: 451-473.

Doyle J. A., HotTon C. L. \& Ward J. V. 1990. Early Cretaceous tetrads, zonasulculate pollen, and Winteraceae. II. Cladistic analysis and implications. American Journal of Botany 77: 1558-1568.

DoYle J. A., Jardiné S. \& Doerenkamp A. 1982. Afropollis, a new genus of early angiosperm pollen, with notes on the Cretaceous palynostratigraphy and paleoenvironments of Northern Gondwana. Bulletin des Centres de Recherche Exploration-Production Elf Aquitaine 6: 39-117.

DuEÑAS Jiménez H. 1989. - Presencia del género Afropollis en Colombia. Boletim do Instituto de Geociências, Publicação Especial - Universidad de São Paulo 7: 155-161.

El-Beialy S. Y., El Atfy H. S., ZaVAda M. S., El Khoriby E. M. \& ABU-ZIE R. H. 2010. — Palynological, palynofacies, paleoenvironmental and organic geo- chemical studies on the Upper Cretaceous succession of the GPTSW-7 well, North Western Desert, Egypt. Marine and Petroleum Geology 27: 370-385.

Ferreira E. P., Carvalho M. A. \& Lima H. P. 2008. Associação palinológica do Aptiano-Cenomaniano da Bacia de São Luis (Norte do Brasil). XII Simpósio de Paleobotânicos e Palinólogos. Florianópolis, SC, Brasil, 2-5th November - Abstracts: 70.

FIET N. 1999. - Stratigraphie intégrée d'une série pélagique à horizons enrichis en matière organique. L'Aptien-Albien du bassin de Marches-Ombrie (Italie Centrale). Thèse École nationale supérieure des Mines de Paris (ENSMP), Mémoires des Sciences de la Terre 36: 1-283.

FiET N. \& PONs D. 1998. — Étude palynologique des black shales albiens du bassin de Marches-Ombrie, implications paléoclimatiques, paléo-océanographiques et stratigraphiques pour les provinces $\mathrm{O}$-téthysienne et N-gondwanienne. Ecole nationale supérieure des Mines de Paris (ENSMP) - Abstracts: 81.

Francis J. E. \& FraKes L. A. 1993. - Cretaceous climates. Sedimentary Reviews 1: 17-30.

Friss E. M., Pedersen K. R. \& Crane P. R. 1999. Early angiosperm diversification: the diversity of pollen associated with angiosperm reproductive structures in Early Cretaceous floras from Portugal. Annals of the Missouri Botanical Garden 86: 259-296.

García A., Segura M., Calonge A. \& Carenas B. 1989. - Unidades estratigráficas para la organización de la sucesión sedimentaria de la plataforma AlbienseCenomaniense de la Cordillera Ibérica. Revista de la Sociedad Geológica de España 2: 303-333.

GeYer O. F. 1995. - Knemiceras uhligi (Choffat) dans la Chaîne Ibérique méridionale (Albien supérieur, Espagne). Batalleria 5: 5-17.

Gil J., Carenas B., Segura M., García Hidalgo J. F. \& García A. 2004. — Revisión y correlación de las unidades litoestratigráficas del Cretácico Superior en la región central y oriental de España. Revista de la Sociedad Geológica de España 17 (3-4): 249-266.

GÓCZÁn F. \& SiEGL-FARKAS A. 1990. — Palynostratigraphical zonation of Senonian sediments in Hungary. Review of Palaeobotany and Palynology 66: 361-377.

Gomez B., Coiffard C., Sender L. M., MartínClosas C., Villanueva-Amadoz U. \& Ferrer J. 2009. - Klitzschophyllites, aquatic basal eudicots (Ranunculales?) from the Upper Albian (Lower Cretaceous) of northeastern Spain. International Journal of Plant Sciences 170: 1075-1085.

Gregory W. A. \& HarT G. F. 1992. — Towards a predictive model for the palynologic response to sea-level changes. Palaios 7: 3-33.

GRÖCKE D. R. 2002. - The carbon isotope composition of ancient $\mathrm{CO}_{2}$ based on higher-plant organic matter. Philosophical Transactions of the Royal Society A 360: 633-658. 
НАвів D. 1972. - Dinoflagellates and other palynomorphs in selected samples from Leg 14, Deep Sea Drilling Project. Deep Sea Drilling Project 14: 649653.

Haq B. U., Hardenbol J. \& Vail P. R. 1988. - Mesozoic and Cenozoic chronostratigraphy and cycles of sea level change, in Wilgus C. K., Hastings C. K., Kendall C. G. S. C., Posamentier H., Ross C. A. \& VAN WAGONER J. C. (eds), Sea level changes: an integrated approach. Society of Economic, Paleontologists and Mineralogists, Special Publication 42: 71-78.

Hasenboelher B. 1981. - Etude paléobotanique et palynologique de l'Albien et du Cénomanien du "Bassin Occidental Portugais" au Sud de l'Accident de Nazaré (Portugal). Thèse 3e Cycle, Université Pierre et Marie Curie, Mémoires Sciences de la Terre nº 81-39, 348 p. (unpublished).

Hay W. W., DeConto R. M., Wold C. N., Wilson K. M., Voigt S., Schulz M., Wold A. R., Dullo W.-C., Ronov A. B., BALUKHOVsKy A. N. \& SÖDING E. 1999. - Alternative global Cretaceous paleogeography. Geological Society of America Special Papers 332: 1-47.

HEDLUND R. W. \& Norris G. 1968. — Spores and pollen grains from Fredericksburguian (Albian) strata, Marshall County, Oklahoma. Pollen et Spores 10 (1): 129-159.

Heimhofer U. \& Hochuli P. A. 2010. — Early Cretaceous angiosperm pollen from a low-latitude succession (Araripe Basin, NE Brazil). Review of Palaeobotany and Palynology 161: 105-126.

Heimhofer U., Hochuli P. A., Burla S. \& WeisSERT H. 2007. - New records of Early Cretaceous angiosperm pollen from Portuguese coastal deposits: implications for the timing of the early angiosperm radiation. Review of Palaeobotany and Palynology 144: 39-76.

HERNGREEN G. F. W. 1973. - Palynology of AlbianCenomanian strata of borehole 1-QS-1-MA, state of Maranhão, Brazil. Pollen et Spores 15: 515-545.

Herngreen G.F.W. 1975. — Palynology of Middle and Upper Cretaceous strata in Brazil. Mededelingen Rijks Geologischen Dienst 26 (3): 39-91.

Herngreen G. F. W. \& Chlonova A.F. 1981. Cretaceous microfloral provinces. Pollen et Spores 23: 441-555.

Herngreen G. F. W. \& Dueñas Jiménez H. 1990. Dating of the Cretaceous Une Formation, Colombia and the relationship with the Albian-Cenomanian African-South American microfloral province. Review of Palaeobotany and Palynology 66: 345-359.

HochUli P. A. 1981. — North Gondwanan floral elements in lower to middle Cretaceous sediments of the Southern Alps (Southern Switzerland, Northern Italy). Review of Palaeobotany and Palynology 35: 337-358.
Hochuli P. A. \& Kelts K. 1980. - Palynology of middle Cretaceous black clay facies from Deep sea Drilling Project Sites 417 and 418 of the western North Atlantic, in Donnelly T. W., Francheteau J., Bryan, W. Robinson, P. Flower, M. \& SAIlsbury, M. (eds), Initial Reports of the Deep sea Drilling Project 51, 52, 53 (2): 897-935.

Horowitz A. 1970. - Jurassic microflora from the northern Negev. Israel Journal of Earth Sciences 19 (3-4): 153-182.

IBRAHIM M. I. A. 1996. - Aptian-Turonian palynology of the Ghazalat-1 Well (GTX-1), Qattara Depression, Egypt. Review of Palaeobotany and Palynology 94: 137-168.

IBRAHIM M. I. A. 2002a. — Late Albian-Middle Cenomanian palynofacies and palynostratigraphy, Abu Gharadig-5 well, Western Desert, Egyt. Cretaceous Research 23: 775-788.

IBRAHIM M. I. A. 2002b. - New angiosperm pollen from the Upper Barremian-Aptian of the western desert, Egypt. Palynology 26: 107-133.

ibrahim M. I. A., Aboul Ela N. M. \& Kholeif S. E. 2001. - Palynostratigraphy of Jurassic to Lower Cretaceous sequence from north eastern Desert of Egypt. Journal of African Earth Sciences 32: 269-297.

JaILLARD E. 1997. - Sintesis estratigráfica y sedimentológica del Cretáceo y Paleogeno de la Cuenca Oriental de Ecuador. Informe Final Convenio ORSTOM Petroproduction, $163 \mathrm{p}$.

Jan du Chêne R. E., De Klasz I. \& Archibong E. E. 1978. - Biostratigraphic study on the borehole OJO-I, SW Nigeria, with special emphasis on the Cretaceous microflora. Revue de Micropaléontologie 21: 123-139.

JARDINÉ S. 1967. - Spores à expansions en forme d'élatères du Crétacé moyen d'Afrique occidentale. Review of Palaeobotany and Palynology 1: 235-258.

Jardiné S. \& Maglorre L. 1965. - Palynologie et stratigraphie du Crétacé des bassins du Sénégal et de Côte d'Ivoire. Mémoire du BRGM 32: 187-245.

Jardiné S., Doerenkamp A. \& Biens P. 1974. Dicheiropollis etruscus, un pollen caractéristique du Crétacé inférieur afro-sudaméricain. Conséquences pour l'évaluation des unités climatiques et implications dans la dérive des continents. Sciences géologiques Bulletin 27: 87-100.

JUHÁSZ M. 1975. — Lycopodiaceae spores from Lower Cretaceous deposits of Hungary. Acta Biologica Szegediensis 21: 21-34.

JuHÁsZ M. 1983. - Palynostratigraphic zonation of the Transdanubian Middle Cretaceous. Acta Geologica Hungarica 26 (1-2): 41-68.

KASKA H.V. 1989. - A spore and pollen zonation of Early Cretaceous to Tertiary nonmarine Sediments of Central Sudan. Palynology 13: 79-90.

Khowaja-Ateequzzaman \& GARg R. 2002. — Dino- 
flagellate cyst evidence for the age of Kulakkalnattam Sandstone Member, Garudamangalam Formation, Cauvery Basin, southern India. The Palaeobotanist 51: 129-143.

Klasz I. De \& Jan du Chêne R. 1978. — Presence of. Albian-Cenomanian in southwestern Nigeria and its paleogeographic implications. Comptes rendus des séances de la Société de Physique et d'Histoire Naturelle de Genève N.S. 13 (1): 10-15.

KLASZ I. De \& Micholet J. 1972. — Eléments nouveaux concernant la biostratigraphie du Bassin gabonais. Proceedings $4^{e}$ Colloque Africain de Micropaléontologie (Abidjan, 1970): 109-143.

Kотоva I. Z. 1978. - Spores and pollen from Cretaceous deposits of the eastern North Atlantic Ocean, Deep Sea Drilling Project, Leg 41, Sites 367 and 370, in Lancelot, Y., Seibold, E. \& Gardner V. (eds). Initial Reports of the Deep Sea Drilling Project 41: 841-881.

LANA C. C. \& Roesner E. H. 2002. - Biocronoestratigrafia de dinoflagelados da seçáo cretácea marinha das bacias do Ceará e Potiguar, margem equatorial brasileira, in Simpósio sobre o Cretáceo do Brasil, 6, São Pedro, SP. Boletim... Rio Claro, UNESP: 239-245.

LegOUX O. 1978. — Quelques espèces de pollen caractéristiques du Néogène du Nigéria. Bulletin des Centres de Recherches Exploration-Production Elf-Aquitaine 2: 265-317.

LiMA M. R. 1976. - Crotonipollis, a new pollen genus from Santana Formation, Cretaceous of northeastern Brazil. Boletín de la Asociación Latinoamericana de Paleobotánica y Palinología 3: 14-20.

LimA M. R. DE 1979. - Paleontologia da Formaçáo Santana (Cretáceo do nordeste do Brasil): estágio atual de conhecimentos. Anais da Academia Brasileira de Ciências 51: 545-556.

LiMA M. R. 1982. - Palinologia da Formacão Codó na Regiaão de Codó, Maranhão. Boletim do Instituto de Geociências - Universidad de São Paulo 13: 116-128.

Lima M. R. \& Campos D. A. 1980. — Palinologia dos folhelhos da fazenda Muzinho, Floriano, Piauí. Boletim Instituto de Geociências - Universidade de São Paulo 11: 149-154.

Ludvigson G. A., Witzke B. J., Joeckel R. M., Ravn R. L., Phillips P. L. , GonZÁlez L. A. \& Brenner R. L. 2010. - New insights on the sequence stratigraphic architecture of the Dakota Formation in Kansas-Nebraska-Iowa from a decade of sponsored research activity. Current Research in Earth Sciences Bulletin 258 (2): Abstract +35 p. (http://www.kgs. ku.edu/Current/2010/Ludvigson/index.html).

Mahmoud M. S. \& MoaWad A. R. M. M. 2000. Jurassic-Cretaceous (Bathonian to Cenomanian) palynology and stratigraphy of the West Tiba-1 borehole, northern Western Desert, Egypt. Journal of African Earth Sciences 30: 401-416.

Martill D. M., Bechly G. \& Loveridge R. F. 2007. The Crato fossil beds of Brazil. Window into an ancient world. Cambridge University Press, Cambridge, $625 \mathrm{p}$.

Masure E. 1988. - Albian-Cenomanian dinoflagellate cysts from sites 627 and 635, Leg 101, Bahamas, in Austin J. A. Jr., SChlager W., Droxler A., Eberli G., Fourcade E., Freeman-Lynde R., Fulthorpe C. S., Harwood G., Kuhn G., Lavoie D., Leckie M., Melillo A. J., Moore A., Mullins H. T., Ravenne C., Sager W. W., SaWrt P., Verbeek J. W., Watkins D. K. \& Williams C. (eds), Proceedings of the Ocean Drilling Program, Scientific Results 101: 121-138.

Masure E. \& Arai M. 2003. - Dinoflagellate cysts from the Middle Cretaceous of the Brazilian Atlantic margin, the Santos Basin. Revue de Micropaléontologie 46: 47-64.

Masure E. \& VRIELYNCK B. 2009. - Late Albian dinoflagellate cysts paleobiogeography as indicator of asymmetric sea surface temperature gradient on both hemispheres with southern high latitudes warmer than northern ones. Marine Micropaleontology 70 (3-4): 120-133.

MÉDus J. 1970. - Première contribution à l'étude palynologique de quelques gisements classiques du Crétacé inférieur de Haute-Provence. Annales de la Faculté des Sciences de Marseille 44: 137-142.

Médus J. \& Triat J. M. 1969. — Le Cénomanien supérieur de la coupe de Laudun (Gard, France): étude palynologique et données sédimentologiques. Review of Palaeobotany and Palynology 9: 213-228.

MORGAN R. 1978. - Albian to Senonian palynology of Site 364, Angola Basin. Initial Reports of the Deep Sea Drilling Project 40: 915-951.

MÜLler H. 1966. - Palynological investigations of Cretaceous sediments in northeastern Brazil. Proceedings of the Second West African Micropaleontological Colloquium, Ibadan, 1965, 123-136.

Müller H. \& Aliaga E. 1981. - Estudio bioestratigráfico del Cretáceo de la cuenca Marañón. Petroperú, informe interno, Lima, 57 p. (unpublished).

NELSON S. N. 2008. - Fossil record of dinoflagellate bloom events associated with the initial opening of the South Atlantic Ocean. 13th International Conference on Harmful Algae, 3-7 November 2008, Hong Kong, Abstracts: 95.

Neumann M. \& SCHRÖEder R. 1985. — Les grands Foraminiferes du Crétacé moyen de la région méditerranénne. Geobios, Mémoire spécial 7: 161.

Pacltová B. \& Lashin M.A. 1998. — Characteristic sporomorphs of elaterates provinces in mid-Cenomanian of Bohemia (Central Europe). Comparison with mid Cretaceous of Egypt (Northern-East Africa). 5th European Paleobotanical and Palynological Conference, 
Cracovie, Abstracts: 135

Pacltová B. \& Lashin M. A. 1999. - Characteristic sporomorphs of elaterates provinces in mid-Cenomanian of Bohemia (Central Europe). Comparison with mid Cretaceous of Egypt (Northern-East Africa). Acta Palaeobotanica Supplementum n ${ }^{\circ}$ 2: 159-165.

Pardo G. \& Villena J. 1979. — Características sedimentológicas y paleogeográficas de la Formación Escucha. Cuadernos de Geología Ibérica 5: 407-418.

PenNy J. H. J. 1989. - New Early Cretaceous forms of the angiosperm pollen genus Afropollis from England and Egypt. Review of Palaeobotany and Palynology 58: 289-299.

Penny J. H. J. 1991. - Early Cretaceous angiosperm pollen from the borehole Mersa Matruh 1, North West Desert, Egypt. Palaeontographica Abt. B 222: 31-88.

Penny J. H. J. 1992. - The relevance of the Early Cretaceous palynology of Egypt to biostratigraphy and reconstruction of angiosperm palaeolatitudinal migrations. Cretaceous Research 13: 369-78.

PlaYFORD G. 1971. — Palynology of Lower Cretaceous (Swan River) strata of Saskatchewan and Manitoba. Palaeontology 14: 533-565.

Pons D. 1988. - Le Mésozoïque de Colombie. Macroflores et microflores. Cahiers de Paléontologie, CNRS (ed.), Paris, $168 \mathrm{p}$.

Pons D., Berthou P.-Y., Filgueira J. B. M. \& SamPAIO J. J. A. 1996. - Palynologie des unités lithostratigraphiques "Fundáo ", "Crato » et "Ipubi » (Aptien supérieur à Albien inférieur moyen, Bassin d'Araripe, NE du Brésil) : enseignements paléoécologiques, stratigraphiques et climatologiques, in JaRdinÉ S., DE KlasZ I. \& DebenaY J. P. (eds), Géologie de l'Afrique et de l'Atlantique sud. C. R. Colloques de Géologie d'Angers, 1994, Angers, France. Bulletin des Centres de Recherches Exploration-Production ElfAquitaine 16: 383-401.

PraUSS M. 2001. - Sea-level changes and organic-walled phytoplankton response in a Late Albian epicontinental setting, Lower Saxony Basin, NW Germany. Palaeogeography, Palaeoclimatology, Palaeoecology 174: 221-249.

QUerol X. 1990. - Distribución de material mineraly azure en los carbones de la Fm. Escucha. Relación con los factores geológicos, sedimentológicos y diagenético. PhD dissertation, Universitat de Barcelona, 509 p. (unpublished).

RaVN R.L. 1986. - Microreticulatisporites sacalii (Deák and Combaz) n. comb, a stratigraphically significant miospore from the Cenomanian of United States. Journal of Paleontology 60: 772-777.

REGALI M.S.P. \& VIANA C.F. 1989. Late Jurassic-Early Cretaceous in Brazilian sedimentary basins: correlation with the international standard scale. Petrobrás, Rio de Janeiro, $95 \mathrm{p}$.
Regali M.S.P., Uesugui N. \& Santos da Silva A. 1974a. - Palinologia dos sedimentos meso-cenozóicos do Brasil (I). Boletím técnico da Petrobrás 17 (34):177-191.

Regali M.S.P., Uesugui N. \& Santos da Silva A. 1974b. - Palinologia dos sedimentos meso-cenozóicos do Brasil (II). Boletím técnico da Petrobrás 17 (4): 263-301.

ReYre Y. 1973. - Palynologie du Mésozoïque saharien. Mémoires du Muséum national d'Histoire naturelle, Série C, Sciences de la Terre 27: 1-284.

RoberTSON ReseArCH 1990. - Palynological Zonation of the Oriente Basin. Informe interno PetroperúRobertson Research: 78-111 (unpublished).

SAAD S. I. 1978. - Palynological studies in the Egyptian Western Desert: Umbarka IX borehole. Pollen et Spores 20: 261-301.

SALAS R. 1987. - El Malm i el Cretaci inferior entre el Massis de Garraf $i$ de la Serra d'Espada. PhD studies, Universitat de Barcelona, 345 p. (unpublished).

Salas R. \& CaSAs A. 1993. - Mesozoic extensional tectonics, stratigraphy and crustal evolution during the Alpine cycle of the eastern Iberian Basin. Crustal controls on the internal architecture of sedimentary basins. Tectonophysics 228: 33-55.

SCHRANK E. 1990. - Palynology of the clastic Cretaceous sediments between Dongola and Wadi Muqaddam, northern Sudan. Berliner geowissenschaftliche Abhandlungen A 120: 149-168.

SCHRANK E. 1994. - Nonmarine Cretaceous palynology of northern Kordofan, Sudan, with notes on fossil Salviniales (water ferns). Geologische Rundschau 83: 773-786.

SCHRANK E. \& Ibrahim M. I. A. 1995. - Cretaceous (Aptian-Maastrichtian) palynology of foraminiferadated wells (KRM-l, AG-18) in northwestern Egypt. Berliner geowissenschaftliche Abhandlungen A 177: $1-44$.

Schrank E. \& Nesterova E. V. 1993. - Palynofloristic changes and Cretaceous climates in Northern Gondwana (NE Africa) and Southern Laurasia (Kazakhstan), in THORWEIHE U. \& SCHANDELMEIER H. (eds), Geoscientific Research in northeast Africa. A.A. Balkema, Rotterdam: 381-390.

Segura M., Carenas B., García-Hidalgo J., García A., SORIA N. \& GIL J. 1994. - Correlación secuencial de los depósitos del Cenomaniense inferior y medio del Sistema Central, Cordillera Ibérica y Catalánides. Cuadernos de Geología Ibérica 18: 217-240.

Sender L. M., Gomez B., Diez J. B., Coiffard C., Martín-Closas C., Villanueva-Amadoz U. \& FerRER J. 2010. - Ploufolia cerciforme gen. et comb. nov.: Aquatic angiosperm leaves from the Upper Albian of north-eastern Spain. Review of Palaeobotany and Palynology 161: 77-86.

SingH C. 1971. - Lower Cretaceous microfloras of 
the Peace River Area, northwestern Alberta. Research Council of Alberta Bulletin 28: 1-299.

STOVER L. E. 1963. - Some middle Cretaceous palynomorphs from west Africa. Micropaleontology 9: 85-94.

SUlTAN I. Z. 1978. - Mid-Cretaceous plant microfossils from the northern part of the Western Desert of Egypt. Review of Palaeobotany and Palynology 25: 259-267.

SulTAN I. Z. 1987. — Palynology of Albian-Cenomanian strata in Mersa Matruh well, Western Desert, Egypt. Journal African Earth Sciences 6: 665-675.

SRIVASTAVA S. K., 1975. - Microspores from the Fredericksburg Group (Albian) of the southern United States, Paléobiologie Continentale 6 (2): 1-119.

Thusu B. \& Van Der Eem J. G. L. A. 1985. - Early Cretaceous (Neocomian-Cenomanian) palynomorphs. Journal of Micropalaeontology 4: 131-150.

Thusu B., van DeR Eem J.G.L.A., El-MehdaWI A. \& Bu-Argoub F. 1988. - Jurassic-Early Cretaceous palynostratigraphy in northeast Libya, in EL-ARNAUTI A., Owens B. \& Thusu B. (eds.), Subsurface Palynostratigraphy of Northeast Libya, Garyounis University Publications, Benghazi, Libya: 171-213.

Uwins P. J. R. \& BATTEN D. J. 1988. — Early to midCretaceous palynology of northeast Libya, in ELArnauti A., Owins B. \& Tsunu B. (eds), Subsurface palynostratigraphy of northeast Libya, Garyounis University Publications, Benghazi, Libya: 215-257.

VACHEY G. \& Jardiné S. 1962. — Aperçu sur la microflore des séries "albiennes" de Côte d'Ivoire. Compte Rendu sommaire des séances de la Société géologique de France 4: 102-104.

VARA M. M. 2003. - Evaluación petrolifera de la Cuenca Santiago. PhD dissertation, Universidad de Lima (UNMSM), 172 p. (unpublished).

VIJAYA 2011. - Palynostratigraphy of subsurface Upper Permian and Mesozoic succession, Rakshitpur area, Raniganj Coalfield, West Bengal. Palaeoworld 20 (1): 61-74.

Vilas L., Mas J. R., García A., Arias C., Alonso A., MELÉNDEZ N. \& RiNCÓN N. 1982. - Ibérica suroccidental, in García A., Alonso A. Canérot J., García-Mondéjar J., Pujalte V., Ramirez del Pozo J., Robles S., Rosell J., SANCHez DE la TorRe L.,
Vera J.A. \& Vilas L. (eds), El Cretácico de España. Universidad Complutense, Madrid: 484-485.

VillanUEVA-AMAdOZ U. 2009. - Nuevas aportaciones palinoestratigráficas para el intervalo Albiense-Cenomaniense en el Sector NE de la Peninsula Ibérica. Implicaciones paleogeográficas y paleoclimáticas. $\mathrm{PhD}$ dissertation, Universidad de Zaragoza, 632 p. (unpublished).

Villanueva-Amadoz U., Pons D., Diez J. B., Ferrer J. \& SENDER L. M. 2010. — Angiosperm pollen grains of San Just site (Escucha Formation) from the Albian of the Iberian Range (north-eastern Spain). Review of Palaeobotany and Palynology 162: 362-381.

VON DER BRELIE G. 1964. - Eine unterkretazische Mikroflora aus dem nördlichen Sauerland. Fortschritte in der Geologie von Rheinland und Westfalen, Krefeld 12: 117-168.

Voronova M. A. 1971. - Palynological evidence of stratigraphical subdivision of Lower Cretaceous deposits in the Dniepr-Donets depression. Naukova Dumka, Kiev: 1-112 (in Russian).

WALKER, J. W., WALKER, A. G. 1984. - Ultrastructure of Lower Cretaceous angiosperm pollen and the origin and early evolution of flowering plants. Annals of the Missouri Botanical Garden 71: 464-521.

WARD J. V. 1986. — Early Cretaceous angiosperm pollen from the Cheyenne and Kiowa Formations (Albian) of Kansas, USA. Palaeontographica B 202: 1- 81.

Williams G. L. 1975. - Dinoflagellate and spore stratigraphy of the Mesozoic-Cenozoic, offshore eastern Canada. Geological Survey of Canada Paper 74-30: 107-161.

Wingate F. H. 1980. - Plant microfossils from the Denton Shale Member of the Bokchito Formation (Lower Cretaceous, Albian) in southern Oklahoma. Oklahoma Geological Survey Bulletin 130: 1-93.

Yans J., Masure E., Dejax J., Pons D. \& Amédro F. 2007. - Influences boréales dans le bassin de Mons (Belgique) à l'Albien. Carnets de Géologie, Mémoire 2007/02 (2007) résumé 06 (CG2007_M02/06).

Zobaa M., Sanchez Botero C., Browne C., ОBohIKuenobe F. E. \& IbRahim M. I. 2008. — Kerogen and palynomorph analyses of the mid-Cretaceous Bahariya Formation and Abu Roash "G" Member, North Western Desert, Egypt. Gulf Coast Association of Geological Societies Transactions 58: 933-943.

Submitted on 3 May 2010; accepted on 2 February 2011. 


\section{APPENDIX}

List of palynomorphs from the studied sections. Distribution of the taxa and their abundance expressed in percentages of the total palynomorph number. The inferred stratigraphic range is represented in light grey. Abbreviations: PS, Puerto de San Just; FV, Fuente del Vaso; PL, Plou; HU, Huesa del Común; ${ }^{\circledR}$, reworked palynomorphs.

\begin{tabular}{|c|c|c|c|c|c|c|c|c|c|c|c|c|c|c|c|c|c|c|c|c|}
\hline \multirow{2}{*}{ samples } & \multicolumn{8}{|c|}{ PS } & \multicolumn{4}{|c|}{ FV } & \multirow{2}{*}{\begin{tabular}{|c|}
$\mathrm{PL}$ \\
0
\end{tabular}} & \multicolumn{7}{|c|}{ HU } \\
\hline & 6 & 7 & 8 & 9 & 10 & 11 & 12 & 13 & 1 & 2 & 3 & 4 & & $\mathbf{I}$ & II & III & B9 & B3 & B2 $\mathrm{B}$ & \begin{tabular}{l|l|} 
B1 & B0 \\
\end{tabular} \\
\hline \multicolumn{21}{|c|}{ BRYOPHYTA } \\
\hline \begin{tabular}{|l|} 
Aequitriradites spinulosus (Cookson \& \\
Dettmann) Cookson \& Detmann, 1961
\end{tabular} & & & & 0.3 & & & & & & 0.3 & & & & & & & & & & \\
\hline Aequitriradites sp. 1 & & & 0.3 & & & & & & & & & & & & & & & & & \\
\hline Aequitriradites sp. 2 & & & 0.3 & & & & & & & & & & & & & & & & & \\
\hline $\begin{array}{c}\text { Antulsporites varigranulatus (Levet- } \\
\text { Carette) Reiser \& Williams, } 1969\end{array}$ & & & & & & & & & & 0.3 & & & & & & & & & & \\
\hline \begin{tabular}{|l} 
Stereisporites antiquasporites \\
(Wilson \& Webster) Dettmann, \\
1963
\end{tabular} & & & & & & & & & & 0.3 & & & & & & & & & & \\
\hline $\begin{array}{l}\text { Triporoletes cenomanianus (Agasie) } \\
\text { Srivastava, } 1977\end{array}$ & & & 0.3 & & 0.3 & & & & & & & & & & & & & & & \\
\hline $\begin{array}{l}\text { Triporoletes laevigatus (Pocock) } \\
\text { Playford, } 1971\end{array}$ & & & & & & & & & & & & 0.4 & & & & & & & & \\
\hline $\begin{array}{l}\text { Triporoletes reticulatus (Pocock) } \\
\text { Playford, } 1971\end{array}$ & & & 0.3 & & 0.3 & & & & & & $3 \Theta$ & & & & & & & & & \\
\hline & & & & & PTEF & $\operatorname{RIDC}$ & $\mathrm{OPH}$ & HYTA & & & & & & & & & & & & \\
\hline Anapiculatisporites sp. & & & & & 0.3 & & 3.2 & & & & & & & & & & & & & \\
\hline Apiculatisporites sp. & & & & & & & & & & & & & & & & & & & & \\
\hline Asbeckiasporites sp. & & & 0.3 & & 0.6 & & 6.4 & & & & & & & & & & & & & \\
\hline $\begin{array}{l}\text { Biretisporites potoniaei Delcourt \& } \\
\text { Sprumont, } 1955\end{array}$ & 0.4 & & & & & & & & 0.3 & & 0.3 & 0.7 & & & & & & & & \\
\hline $\begin{array}{l}\text { Camarozonosporites insignis } \\
\text { Norris, } 1967\end{array}$ & & & 0.8 & & 1.6 & & 3.2 & 0.4 & 0.7 & & & 0.4 & & 0.4 & & 0.7 & & & & \\
\hline Camarozonosporites sp. 1 & & & & & & & 3.2 & & & & & & & & & & & & & \\
\hline Camarozonosporites sp. 2 & & & & & & & & & & & 0.7 & & & & & & & & & \\
\hline $\begin{array}{l}\text { Cibotiumspora juncta (Kara-Murza) } \\
\text { Singh, } 1983\end{array}$ & 0.4 & & & & 0.3 & & & & 0.3 & & 0.3 & & & & & & & & & \\
\hline $\begin{array}{l}\text { Cicatricosisporites sp. cf. A. exilioides } \\
\text { (Maljavkina) Bolkhovitina, } 1961\end{array}$ & & 0.3 & & & & & 3.2 & & & & & 0.4 & & & & & & & & \\
\hline $\begin{array}{l}\text { Cicatricosisporites coconinoensis } \\
\text { Agasie, } 1969\end{array}$ & & & & & & & & 0.4 & & & & & & & & & & & & \\
\hline $\begin{array}{l}\text { Cicatricosisporites hallei Delcourt \& } \\
\text { Sprumont, } 1955\end{array}$ & ( & & & (®) & & & & 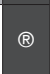 & & 0.3 & 0.7 & & & & & & & & & \\
\hline $\begin{array}{l}\text { Cicatricosisporites hughesi } \\
\text { Dettmann, } 1963\end{array}$ & & & 0.3 & & & & & & 0.3 & 0.3 & & & & & & & & & & \\
\hline $\begin{array}{l}\text { Cicatricosisporites imbricatus } \\
\text { (Markova) Singh, } 1971\end{array}$ & & & & & & & 3.2 & & & & & & & & & & & & & \\
\hline \begin{tabular}{|l} 
Cicatricosisporites sp. cf. C. \\
imbricatus (Markova) Singh, 1971
\end{tabular} & & & & & & & & 0.4 & & & & & & & & & & & & \\
\hline $\begin{array}{l}\text { Cicatricosisporites minutaestriatus } \\
\text { (Bolkhovitina, 1961) Pocock, } \\
1964\end{array}$ & & & 0.3 & & & & & & & & & & & & & & & & & \\
\hline $\begin{array}{l}\text { Cicatricosisporites myrtellii Burger, } \\
1966\end{array}$ & & & & & & & 3.2 & & & & & & & & & & & & & \\
\hline
\end{tabular}




\begin{tabular}{|c|c|c|c|c|c|c|c|c|c|c|c|c|c|c|c|c|c|c|c|c|c|}
\hline \multirow{2}{*}{ samples } & \multicolumn{8}{|c|}{ PS } & \multicolumn{4}{|c|}{ FV } & PL & \multicolumn{8}{|c|}{ HU } \\
\hline & 6 & 7 & 8 & 9 & 10 & 11 & 12 & 13 & 1 & 2 & 3 & 4 & 0 & I & II & III & B9 & B3 & B2 & B1 & B0 \\
\hline $\begin{array}{l}\text { Cicatricosisporites perforatus } \\
\text { (Bolkhovitina) Singh, } 1964\end{array}$ & & 0.3 & & & & & & & & & & & & & & & & & & & \\
\hline $\begin{array}{l}\text { Cicatricosisporites pseudotripartitus } \\
\text { (Bolkhovitina) Dettmann, } 1963\end{array}$ & & & 0.3 & & 1.3 & & & & & 0.3 & & & & & & & & & & & \\
\hline $\begin{array}{l}\text { Cicatricosisporites subrotundus } \\
\text { Brenner, } 1963\end{array}$ & & & 0.5 & & 0.3 & & & & & & 0.3 & & & & & & & & & & \\
\hline $\begin{array}{l}\text { Cicatricosisporites venustus Deák, } \\
1963\end{array}$ & & & 0.3 & & 0.3 & & & & & & & & & & & & & & & & \\
\hline Cicatricosisporites sp. 1 & & & 0.3 & & & & & & & & & & & & & & & & & & \\
\hline Cicatricosisporites sp. 3 & & & & & 0.3 & & & & & & & & & & & & & & & & \\
\hline Cicatricosisporites sp. 4 & & & 1 & & 0.3 & & & & & & & & & & & & & & & & \\
\hline $\begin{array}{l}\text { Concavisporites punctatus } \\
\text { Delcourt \& Sprumont, } 1955\end{array}$ & & 0.3 & & & 0.3 & & & & 0.3 & & & & & & & & & & & & \\
\hline $\begin{array}{l}\text { Concavissimisporites verrucosus } \\
\text { (Delcourt \& Sprumont) Delcourt } \\
\text { et al., } 1963\end{array}$ & & & & & 0.3 & & & & 0.7 & 1.3 & 0.7 & & & & & & & & & & \\
\hline $\begin{array}{l}\text { Converrucosisporites } \\
\text { platyverrucosus Brenner, } 1963\end{array}$ & & & & & 0.3 & & & & & & & & & & & & & & & & \\
\hline $\begin{array}{l}\text { Coronatispora valdensis (Couper) } \\
\text { Dettmann, } 1963\end{array}$ & & & & & & & 3.2 & & & & & & & & & & & & & & \\
\hline Coronatispora sp. & & & 0.3 & & 0.3 & & & & & & & & & & & & & & & & \\
\hline $\begin{array}{l}\text { Costatoperforosporites foveolatus } \\
\text { Deák, } 1962\end{array}$ & & & & & 0.3 & & & & & & & & & & & & & & & & \\
\hline $\begin{array}{r}\text { Crybelosporites pannuceus } \\
\text { (Brenner) Srivastava, } 1975\end{array}$ & & & 0.3 & & 0.6 & & & & 0.3 & 0.3 & & 0.4 & & & $6.4 ®$ & & & & & & \\
\hline Crybelosporites sp. & & & & & & & & & & 0.3 & & & & & & & & & & & \\
\hline Cyathidites australis Couper, 1953 & 2.5 & 3 & 1.8 & 3.7 & 0.6 & & & (®) & 4.1 & 3.3 & 3.1 & 1.1 & 10 & 1.3 & & & 1.1 & & & & 0.2 \\
\hline Cyathidites minor Couper, 1953 & 12 & 1.3 & 12 & 7.7 & 7.2 & 13 & 3.2 & 3.8 & 6.4 & 13 & 13 & 9.3 & 1.5 & & & 0.7 & & & 0.3 & & 0.1 \\
\hline $\begin{array}{l}\text { Deltoidospora psilostoma } \\
\text { Rouse, } 1959\end{array}$ & & & & 0.3 & & & & & 0.3 & 0.3 & 1.4 & & & & & & & & & & \\
\hline Deltoidospora sp. & 0.4 & & 0.3 & & & & & & 0.3 & & 0.3 & & & & & & & & & & \\
\hline $\begin{array}{l}\text { Dictyophyllidites harrisii } \\
\text { Couper, } 1958\end{array}$ & & & 0.3 & 0.3 & & & & & & & 0.3 & 1.9 & & & & & & & & & \\
\hline Distaltriangulisporites sp. & & & & & & & & & 0.3 & & & & & & & & & & & & \\
\hline $\begin{array}{l}\text { Fisciniasporites brevilaesuratus } \\
\text { (Couper) Dettmann \& Clifford, } \\
1992\end{array}$ & & & & & 0.3 & & & & & & & & & & & & & & & & \\
\hline $\begin{array}{l}\text { Foveosporites subtriangularis } \\
\text { Brenner, } 1963\end{array}$ & & 0.3 & & & & & & & & & & & & & & & & & & & \\
\hline $\begin{array}{l}\text { Gabonisporis pseudoreticulatus } \\
\text { Boltenhagen, } 1975\end{array}$ & & 2.3 & 3.4 & 1 & 3.8 & & 3.2 & 0.4 & 0.7 & 1.3 & 4.8 & & & & & & & & & & \\
\hline Gabonisporis sp. & & & & & 0.3 & & & & 1 & & & & & & & & & & & & \\
\hline $\begin{array}{l}\text { Gleicheniidites senonicus } \\
\text { Ross, } 1949\end{array}$ & 0.8 & & 0.8 & 2 & 0.3 & & 3.2 & & 1.4 & 0.3 & 2.8 & 4.5 & & & & & & & & & \\
\hline Heliosporites sp. & & & & & & & 3.2 & & & & & & & & & & & & & & \\
\hline \begin{tabular}{|l|} 
Impardecispora sp. cf. crassa \\
(Brenner) Burden \& Hill, 1989
\end{tabular} & & & & & & & & & & & 0.3 & & & & & & & & & & \\
\hline
\end{tabular}




\begin{tabular}{|c|c|c|c|c|c|c|c|c|c|c|c|c|c|c|c|c|c|c|c|c|c|}
\hline \multirow{2}{*}{ samples } & \multicolumn{8}{|c|}{ PS } & \multicolumn{4}{|c|}{ FV } & \multirow{2}{*}{\begin{tabular}{|c|} 
PL \\
0
\end{tabular}} & \multicolumn{8}{|c|}{ HU } \\
\hline & 6 & 7 & 8 & 9 & 10 & 11 & 12 & 13 & 1 & 2 & 3 & $4 \mid$ & & $\mathbf{I}$ & II & III & B9 & B3 & B2 & B1 & Bo \\
\hline $\begin{array}{l}\text { Impardecispora marylandensis } \\
\text { (Brenner) Srivastava, } 1975\end{array}$ & & & & & & & & & & & & 0.3 & & & & & & & & & \\
\hline $\begin{array}{l}\text { Impardecispora trioreticulosa } \\
\text { (Cookson \& Dettmann) } \\
\text { Venkatachala et al., } 1969\end{array}$ & & & & & & & & & 0.7 & $\begin{array}{lll}0.7 & 0\end{array}$ & 0.3 & D.7 & & & & & & & & & \\
\hline $\begin{array}{l}\text { Ischyosporites disjunctus } \\
\text { Singh, } 1971\end{array}$ & & & & & & & & & & & & D. 4 & & & & & & & & & \\
\hline $\begin{array}{l}\text { Klukisporites sp. cf. Klukisporites } \\
\text { foveolatus Pocock, } 1964\end{array}$ & & & & & & & & & & & & & & & & & & & & & \\
\hline $\begin{array}{l}\text { Klukisporites sp. cf. Klukisporites } \\
\text { variegatus Couper, } 1958\end{array}$ & & & 0.3 & & & & & & & & & & & & & & & & & & \\
\hline $\begin{array}{l}\text { Laevigatosporites haardtii } \\
\text { (Potonié \& Venitz) Thomson \& } \\
\text { Pflug, } 1953\end{array}$ & 0.8 & & 0.3 & 0.3 & & & & & & & & 1.1 & & & & & & & & & \\
\hline $\begin{array}{l}\text { Leptolepidites verrucatus Couper, } \\
1953\end{array}$ & & & & & 0.3 & 13 & & & & & & $3 \otimes$ & & & & & & & & & \\
\hline $\begin{array}{l}\text { Lophotriletes babsae (Brenner) } \\
\text { Singh, } 1971\end{array}$ & & & & & & & & & 0.3 & & & $3 \otimes$ & & & & & & & & & \\
\hline $\begin{array}{l}\text { Matonisporites equiexinus Couper, } \\
1958\end{array}$ & 0.4 & 0.3 & 0.3 & 0.7 & 0.6 & & & $0.3 \otimes$ & 0.37 & $\begin{array}{lll}7.6 & 0\end{array}$ & \begin{tabular}{l|l}
0.3 & 0
\end{tabular} & D.7 & & & & & & & & & \\
\hline $\begin{array}{l}\text { Microfoveolatosporis baconicus } \\
\text { Juhász, } 1977\end{array}$ & & & & & & & & & 0.3 & & 0.3 & & & & & & & & & & \\
\hline $\begin{array}{l}\text { Microreticulatisporites } \\
\text { crassiexinous Brenner, } 1963\end{array}$ & & & & & & & & & & & & 0.4 & & & & & & & & & \\
\hline $\begin{array}{l}\text { Neoraistrickia robusta } \\
\text { Brenner, } 1963\end{array}$ & & & & & & & & & 0.3 & & 0.7 & & & & & & & & & & \\
\hline $\begin{array}{l}\text { Neoraistrickia truncata (Cookson) } \\
\text { Potonié, } 1956\end{array}$ & & & & & 0.3 & & & & & & & & & & & & & & & & \\
\hline Nodosisporites sp. 1 & & & & & & & & & & 0.3 & & & & & & & & & & & \\
\hline Nodosisporites sp. 2 & & & 0.8 & & & & & 0.4 & & 0.3 & & & & & & & & & & & \\
\hline $\begin{array}{l}\text { Patellasporites distaverrucosus } \\
\text { (Brenner) Kemp, } 1970\end{array}$ & & $\circledast$ & 0.3 & & 2.2 & & & & 0.30 & 0.3 & & & & & & & & & & & \\
\hline $\begin{array}{l}\text { Patellasporites tavadarensis } \\
\text { Groot \& Groot, } 1962\end{array}$ & $\circledast$ & 0.3 & 2.1 & 4.73 & 3.4 & 13 & 3.2 & 0.4 & 0.70 & 0.30 . & & & & & & & & & & & \\
\hline Patellasporites sp. & & & & & 0.9 & & & & & & & & & & & & & & & & \\
\hline Perinomonoletes sp. & & & & & & & & & 0.3 & & & & & & & & & & & & \\
\hline Peromonolites fragilis Burger, 1966 & & & & & & & 3.2 & & 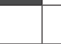 & & & & & & & & & & & & \\
\hline Peromonolites sp. & & 1.7 & 15 & & 0.3 & & & 0.8 & 134 & 4.3 & & & 1.5 & 0.4 & & & & & & & \\
\hline $\begin{array}{l}\text { Plicatella appendicifera (Thiergart) } \\
\text { Davies, } 1985\end{array}$ & & & & & & & & & & & & 0.4 & & & & & & & & & \\
\hline $\begin{array}{l}\text { Plicatella bilateralis (Singh) } \\
\text { Dörhöfer, } 1977\end{array}$ & & & & & & & & & & 0.3 & & & & & & & & & & & \\
\hline $\begin{array}{l}\text { Plicatella cristata (Markova) Davies, } \\
1985\end{array}$ & & & & & & & & & 0.6 & & 0.6 & & & & & & & & & & \\
\hline $\begin{array}{l}\text { Plicatella gigantica (Groot \& Groot, } \\
\text { 1962) Davies, } 1985\end{array}$ & & & 0.3 & & & & & & & & & & & & & & & & & & \\
\hline $\begin{array}{l}\text { Plicatella potomacensis (Brenner) } \\
\text { Davies, } 1985 \\
\end{array}$ & & 0.3 & & & & & & & & & & & & & & & & & & & \\
\hline
\end{tabular}




\begin{tabular}{|c|c|c|c|c|c|c|c|c|c|c|c|c|c|c|c|c|c|c|c|c|c|}
\hline \multirow{2}{*}{ samples } & \multicolumn{8}{|c|}{ PS } & \multicolumn{4}{|c|}{ FV } & \multirow{2}{*}{\begin{tabular}{|c|}
$\mathrm{PL}$ \\
0
\end{tabular}} & \multicolumn{8}{|c|}{ HU } \\
\hline & 6 & 7 & 8 & 9 & 10 & 11 & 12 & 13 & 1 & 2 & 3 & 4 & & I & II & III & B9 $\mathrm{E}$ & $33 \mathrm{E}$ & \begin{tabular}{c|c}
$\mathrm{B}$ & $\mathrm{B}$ \\
\end{tabular} & \begin{tabular}{l|l} 
B1 & B \\
\end{tabular} & BO \\
\hline $\begin{array}{l}\text { Plicatella sp. cf. P. potomacensis } \\
\text { (Brenner) Davies, } 1985\end{array}$ & & & & & 0.3 & & & & & & & & & & & & & & & & \\
\hline $\begin{array}{l}\text { Plicatella problematica (Burger) } \\
\text { Davies, } 1985\end{array}$ & & 0.3 & 0.3 & & & & & & 0.3 & & 0.3 & & & & & & & & & & \\
\hline $\begin{array}{l}\text { Plicatella triceps (Weyland \& } \\
\text { Krieger) Sung, Li \& Li, } 1976\end{array}$ & & & $(\AA$ & & & & & & & & & & & & & & & & & & \\
\hline $\begin{array}{l}\text { Plicatella tricostata (Bolkhovitina) } \\
\text { Davies, } 1985\end{array}$ & & & & & 0.3 & & & & & & & & & & & & & & & & \\
\hline $\begin{array}{l}\text { Plicatella unica (Markova) Dörhöfer, } \\
1977\end{array}$ & & & & & & & & & & & & & & & & & & & & & \\
\hline \begin{tabular}{|l|} 
Polycingulatisporites reduncus \\
(Bolkhovitina) Playford \& \\
Dettmann, 1965 \\
\end{tabular} & & & 0.3 & 0.3 & & & & & & & & & & & & & & & & & \\
\hline $\begin{array}{l}\text { Reticulatisporites arcuatus Brenner, } \\
1963\end{array}$ & & & & & 0.3 & & & & & & & & & & & & & & & & \\
\hline $\begin{array}{l}\text { Reticulatisporites elongatus Singh, } \\
1971\end{array}$ & 2.5 & & & & & & & & & & & & & & & & & & & & \\
\hline Reticulisporites sp. 1 & & & & & & & & & & 0.3 & & & & & & & & & & & \\
\hline $\begin{array}{l}\text { Ruffordiaspora australiensis } \\
\text { (Cookson) Dettmann \& Clifford, } \\
1992\end{array}$ & & & & & 0.6 & & & & & & 1.4 & & & & & & & & & & \\
\hline $\begin{array}{l}\text { Taurocusporites segmentatus } \\
\text { Stover, } 1962\end{array}$ & & & 0.5 & 0.3 & & & 3.2 & & & & & & & & & & & & & & \\
\hline Todisporites major Couper, 1958 & & & & & & & & & & & & 0.7 & & & & & & & & & \\
\hline Todisporites minor Couper, 1958 & & & & & & & & & 0.3 & & & & & & & & & & & & \\
\hline $\begin{array}{l}\text { Undulatisporites sinuosis Groot \& } \\
\text { Groot, } 1962\end{array}$ & & & & & & & & & & & & & & & & & & & & & \\
\hline $\begin{array}{l}\text { Undulatisporites undulapolus } \\
\text { Brenner, } 1963\end{array}$ & & & 0.3 & & 0.3 & & & & & 0.3 & & & & & & & & & & & \\
\hline $\begin{array}{l}\text { Vadaszisporites sacalii Deák \& } \\
\text { Combaz, } 1967\end{array}$ & & & & & & & & 1.9 & & & & & & & & & & & & & \\
\hline Vinculisporites flexus Deák, 1964 & & & & & & & & & & & 0.3 & 0.4 & & & & & & & & & \\
\hline & & & & & GYM & IN & o. & RMS & & & & & & & & & & & & & \\
\hline $\begin{array}{l}\text { Alisporites grandis (Cookson) } \\
\text { Dettmann, } 1963\end{array}$ & & 2.5 & $0.5 \mathrm{c}$ & 0.3 & & & & & 0.3 & & 0.7 & 0.4 & 5.9 & & & 2.6 & & & & & \\
\hline $\begin{array}{l}\text { Applanopsis dampieri (Balme) } \\
\text { Döring, } 1961\end{array}$ & 0.4 & & 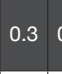 & 0.3 & 0.6 & & & 0.4 & 0.6 & 0.6 & & 0.4 & & & & & & & & & \\
\hline $\begin{array}{l}\text { Applanopsis segmentatus (Balme) } \\
\text { Venkatachala \& Kar, } 1969\end{array}$ & & & & & & & & & 0.3 & & & 0.4 & & & & & & & & & \\
\hline \begin{tabular}{|l|} 
Applanopsis trilobatus (Balme) \\
Venkatachala \& Kar, 1969 \\
\end{tabular} & & & & & & & & & & & & & & 0.3 & & & & & & & \\
\hline Applanopsis sp. & & & & & 0.3 & & & & & & & & & & & & & & & & \\
\hline $\begin{array}{l}\text { Araucariacites australis Cookson ex } \\
\text { Couper, } 1953\end{array}$ & 17.7 & 1 & 7.1 & 4 & 2.2 & & & & 4.4 & 6.6 & 4.1 & 4.1 & 8.8 & 7.8 & 8.5 & 2.61 & 1.1 & & 0.3 & & 0.1 \\
\hline $\begin{array}{l}\text { Araucariacites hungaricus } \\
\text { Deák, } 1964\end{array}$ & & & & & & & & & & & 0.7 & 1.1 & & & & & & & & & \\
\hline $\begin{array}{l}\text { Balmeiopsis limbata (Balme) } \\
\text { Archangelsky, } 1977 \\
\end{array}$ & & & & & 1.6 & & & & & 1.7 & 0.7 & 6 & 2.9 & & & & & & & & \\
\hline
\end{tabular}




\begin{tabular}{|c|c|c|c|c|c|c|c|c|c|c|c|c|c|c|c|c|c|c|c|c|c|}
\hline \multirow{2}{*}{ samples } & \multicolumn{8}{|c|}{ PS } & \multicolumn{4}{|c|}{ FV } & \multirow{2}{*}{\begin{tabular}{|c|}
$\mathrm{PL}$ \\
0
\end{tabular}} & \multicolumn{8}{|c|}{ HU } \\
\hline & 6 & 7 & 8 & 9 & 10 & 11 & 12 & 13 & 1 & 2 & 3 & 4 & & I & II & III & \begin{tabular}{l|l} 
B9 & B \\
\end{tabular} & \begin{tabular}{l|l}
$B 3$ & $B$ \\
\end{tabular} & \begin{tabular}{l|l}
32 & $E$ \\
$E$
\end{tabular} & B1 & B0 \\
\hline $\begin{array}{l}\text { Cedripites canadensis } \\
\text { Pocock, } 1962 \\
\end{array}$ & & & & & 0.3 & & & & 0.3 & & 0.7 & & & & & & & & & & \\
\hline $\begin{array}{l}\text { Classopollis classoides Pflug } \\
\text { emend. Pocock \& Jansonius, } \\
1961\end{array}$ & 31 & 17 & 19 & 39 & 22 & & 3.2 & 17 & 1.4 & 5.3 & 4.8 & 1.5 & & & & & & & & & \\
\hline $\begin{array}{l}\text { Classopollis major Groot \& Groot, } \\
1962\end{array}$ & & & & & & & & 1.5 & & & & & & & & & & & & & \\
\hline $\begin{array}{l}\text { Cycadopites carpentieri (Delcourt \& } \\
\text { Sprumont) Singh, } 1964\end{array}$ & & & & & & & & & 0.3 & & & & & & & & & & & & \\
\hline Cycadopites sp. 1 & & & & & & & & & & & & & 1.5 & & & & & & & & \\
\hline Cycadopites sp. 2 & 0.4 & & & & 0.6 & & & & 0.3 & 0.3 & & & & & & & & & & & \\
\hline Cycadopites sp. 3 & & & 0.3 & & & & & & & & & & & & & & & & & & \\
\hline Cycadopites sp. 4 & & & & & & & & & & & & & 1.5 & & & & & & & & \\
\hline Cycadopites sp. 5 & & & & & & & & & & & & & $G$ & 0.4 & & 0.7 & & & $0.3 \mathrm{C}$ & 0.7 & 0.1 \\
\hline Cycadopites sp. 7 & & & & & & & & & & & & & 1.5 & & & & & & & & \\
\hline \begin{tabular}{|l|} 
Elaterosporites klaszii \\
(Jardiné \&Magloire) Jardiné, 1967
\end{tabular} & & & & & & & & & & & 0.7 & & & & & & & & & & \\
\hline $\begin{array}{l}\text { Ephedripites multicostatus Brenner, } \\
1963\end{array}$ & & & & & & & & & 0.3 & 0.3 & & & & & & & & & & & \\
\hline $\begin{array}{l}\text { Equisetosporites ambiguus } \\
\text { (Hedlund) Singh, } 1983 \\
\end{array}$ & & & & & & & & & 0.3 & 0.3 & & & 1.5 & & & & & & & & \\
\hline $\begin{array}{l}\text { Eucommiidites minor Groot \& } \\
\text { Penny, } 1960\end{array}$ & & & & & & & & & 0.3 & & 0.3 & 0.4 & & & & & & & & & \\
\hline $\begin{array}{l}\text { Eucommiidites troedssonii } \\
\text { (Erdtman) Potonié, } 1958\end{array}$ & ${ }^{\circledR}$ & & & & & & & & & 0.3 & 0.3 & & & & & & & & & & \\
\hline Eucommiidites sp. - Kemp 1970 & & & & & & & & & & & & 0.3 & & & & & & & & & \\
\hline $\begin{array}{l}\text { Exesipollenites tumulus Balme, } \\
1957\end{array}$ & 4.5 & & 0.3 & 7 & 0.9 & & & & 1 & 4.3 & 0.7 & 0.7 & & & & & & & & & \\
\hline $\begin{array}{l}\text { Parvisaccites radiatus Couper, } \\
1958\end{array}$ & & & & & & & & & & & & 0.4 & & & & & & & & & \\
\hline \begin{tabular}{|l} 
Perinopollenites halonatus \\
Phillips \& Felix, 1971
\end{tabular} & 0.4 & & & & 0.3 & & 3.2 & 0.4 & 0.7 & 1 & & 1.5 & & & & & & & & & \\
\hline \begin{tabular}{|l|} 
Podocarpidites biformis Rouse, \\
1957
\end{tabular} & & 1.3 & 2.4 & 0.3 & 5.3 & & & 0.4 & 0.3 & & 0.3 & & & & & & & & & & \\
\hline $\begin{array}{l}\text { Podocarpidites ornatus Pocock, } \\
1962\end{array}$ & & & & & & & & & & & & & & & & & & & 0.3 & & \\
\hline $\begin{array}{l}\text { Podocarpidites potomacensis } \\
\text { Brenner, } 1963\end{array}$ & & & & & & & & & & & 1.4 & & & & & & & & & & \\
\hline Singhia acicularis Lima, 1980 & & & & & 0.9 & & & & 0.3 & & & & & & & & & & & & \\
\hline Singhia minima Lima, 1980 & & & & & & & 3.2 & & 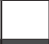 & & & & & & & & & & & & \\
\hline $\begin{array}{l}\text { Spheripollenites psilatus Couper, } \\
1958\end{array}$ & 4.1 & 1.7 & & 2.3 & 5.6 & & & 0.4 & 3.1 & 0.7 & 0.7 & 0.4 & 1.5 & 0.9 & 1.1 & 6.6 & & & 0.3 & 0.2 & \\
\hline \begin{tabular}{|l|} 
Taxodiaceaepollenites hiatus \\
(Potonié) Kremp, 1949 \\
\end{tabular} & 7.7 & 3 & 1.8 & 6.3 & 1.3 & 13 & 12.9 & 3 & 7.8 & 24.8 & 23.8 & 4.1 & $4.4(x-r) x)$ & 0.9 & 2.1 & 0.7 & & & & & \\
\hline & & & & & ANC & tOS & PEER & $\mathrm{RMS}$ & & & & & & & & & & & & & \\
\hline Afropollis jardinus Doyle et al., 1982 & 3.7 & 2.7 & 2.3 & 0.3 & 0.6 & 13 & 3.2 & 1.12 & 29.2 & 2 & 20.74 & 43.3 & 4.47 & 73.36 & 63.86 & 51.89 & & & & & 98.9 \\
\hline $\begin{array}{l}\text { Clavatipollenites hughesii Couper, } \\
1958\end{array}$ & 2.5 & 4.7 & 6.8 & 4.4 & 0.6 & & & & 3.4 & 2.6 & 1 & 0.4 & 1.5 & & & 0.7 & & & & $1.7 \mathrm{C}$ & 0.1 \\
\hline
\end{tabular}




\begin{tabular}{|c|c|c|c|c|c|c|c|c|c|c|c|c|c|c|c|c|c|c|c|c|c|}
\hline \multirow{2}{*}{ samples } & \multicolumn{8}{|c|}{ PS } & \multicolumn{4}{|c|}{ FV } & $\mathbf{P L}$ & \multicolumn{8}{|c|}{ HU } \\
\hline & 6 & 7 & 8 & 9 & 10 & 11 & 12 & 13 & 1 & 2 & 3 & 4 & 0 & I & II & III & B9 & B3 & B2 & B1 & B0 \\
\hline $\begin{array}{l}\text { Clavatipollenites minutus Brenner, } \\
1963\end{array}$ & 5.3 & 3 & & 2.7 & 0.6 & & & & & & 0.3 & & 1.5 & 0.4 & 1.1 & 3.3 & 2.2 & 6.7 & & 0.7 & \\
\hline Clavatipollenites sp. & & 2 & 0.3 & 1.7 & 0.6 & & & & 0.7 & 0.3 & & 0.4 & 4.4 & 0.9 & & 0.7 & 1.5 & & 1.2 & 2.2 & 0.1 \\
\hline $\begin{array}{l}\text { Dichastopollenites dunveganensis } \\
\text { Singh, } 1983\end{array}$ & & & & & & & & & 0.3 & & & & & 0.4 & & & & & & & \\
\hline $\begin{array}{l}\text { Dichastopollenites sp. cf. } \\
\text { D. reticulatus May, } 1975\end{array}$ & & & & & & & & & & & & 0.4 & & & & & & & & & \\
\hline Echimonocolpites sp. & & & & & & & & & & & & 0.4 & & & & & & & & & \\
\hline $\begin{array}{l}\text { Hammenia fredericksburgensis } \\
\text { (Hedlund \& Norris) Ward, } 1986\end{array}$ & & 0.3 & 0.5 & & & & & & & & & & & & & & & & & 0.2 & \\
\hline Liliacidites doylei Ward, 1986 & & & & & & & & & & & & & & 0.4 & & & & & & & \\
\hline Liliacidites inaequalis Singh, 1971 & & & & & & & & & & & & & & & & 0.7 & & & & & \\
\hline $\begin{array}{l}\text { Monosulcites chaloneri Brenner, } \\
1963\end{array}$ & & & & 0.3 & & & & & & & & & & & & & & & & & \\
\hline $\begin{array}{l}\text { Monosulcites minimus Cookson, } \\
1947\end{array}$ & & & & & & & & & & & & & & & & & & & 0.3 & & \\
\hline $\begin{array}{l}\text { Penetetrapites mollis Hedlund \& } \\
\text { Norris, } 1968\end{array}$ & & & & & & & & & & 1 & & 1.5 & & 0.4 & & & & & & & \\
\hline $\begin{array}{l}\text { Pennipollis escuchensis Villanueva- } \\
\text { Amadoz et al., } 2010\end{array}$ & & & & & & & & & & & 0.7 & & & & & & & & & & \\
\hline $\begin{array}{l}\text { Pennipollis peroreticulatus } \\
\text { (Brenner) Friis et al., } 2000\end{array}$ & & & 0.3 & 0.3 & & & & & & & & & & & & & & & 0.3 & & \\
\hline $\begin{array}{l}\text { Pennipollis reticulatus (Brenner) } \\
\text { Friis et al., } 2000\end{array}$ & & & & & & & 6.4 & & & 1 & & & & & & & & & & & \\
\hline Pennipollis sp. & & & & & & & & & & & & & & & & & & & 0.3 & & 0.1 \\
\hline $\begin{array}{l}\text { Retimonocolpites dividuus (Pierce) } \\
\text { Brenner, } 1963\end{array}$ & & & & 0.3 & & & & & & & & & & & & & & & & & \\
\hline $\begin{array}{l}\text { Retimonocolpites fragilis Pierce, } \\
1961\end{array}$ & & & & & & & & & & & & & & & & & & 3.3 & 0.6 & & 0.1 \\
\hline $\begin{array}{l}\text { Retimonocolpites textus (Norris) } \\
\text { Singh, } 1983\end{array}$ & & & & & & & & & & & & & 2.9 & & & & & & & & \\
\hline $\begin{array}{l}\text { Retitricolpites virgeus (Groot et al.) } \\
\text { Brenner, } 1963\end{array}$ & & & & & 0.3 & & & & & & & & & & & & & & & & \\
\hline $\begin{array}{l}\text { Rousea brenneri (Couper) Singh, } \\
1983\end{array}$ & & & & & & & & & & & & & 7.3 & & & & & & & & \\
\hline $\begin{array}{l}\text { Rousea georgensis (Brenner) } \\
\text { Dettmann, } 1973\end{array}$ & & & & & & & & & & & & & 2.9 & & & & & & & & \\
\hline Rousea marthae Ward, 1986 & & & & & & & & & & & & & & & & & & & & & \\
\hline Rousea sp. B in Burger 1993 & & & & & & & 3.2 & & & & & & & & & & & & & & \\
\hline Rousea sp. & & & & & & & & & & & & & & 0.4 & & & & & & & \\
\hline $\begin{array}{l}\text { Senectotetradites varireticulatus } \\
\text { (Dettmann) Singh, } 1983\end{array}$ & & & & & & & & & & & 0.7 & & & & & & & & & & \\
\hline Similipollis sp. & & & & & & 13 & & & & & & & 0.3 & & & & & & & & \\
\hline $\begin{array}{l}\text { Stellatopollis barghornii Doyle, } \\
1975\end{array}$ & & 0.3 & 0.3 & & 0.6 & & & 0.4 & 3.4 & 1.7 & & 3.4 & 14.7 & & 1.1 & 0.7 & 0.7 & & 0.3 & 0.5 & 0.1 \\
\hline $\begin{array}{l}\text { Striatopollis paraneus (Norris) } \\
\text { Singh, } 1971\end{array}$ & & & & & & & & & & & & 0.4 & & & & & & & & & \\
\hline
\end{tabular}


APPENDIX. - Continuation.

\begin{tabular}{|c|c|c|c|c|c|c|c|c|c|c|c|c|c|c|c|c|c|c|c|c|c|}
\hline \multirow{2}{*}{ samples } & \multicolumn{8}{|c|}{ PS } & \multicolumn{4}{|c|}{ FV } & PL & \multicolumn{8}{|c|}{ HU } \\
\hline & 6 & 7 & 8 & 9 & 10 & 11 & 12 & 13 & 1 & 2 & 3 & 4 & 0 & $\mathbf{I}$ & II & III & B9 & \begin{tabular}{|l|l} 
B3 & $\mathrm{E}$ \\
\end{tabular} & \begin{tabular}{l|l} 
B2 & B \\
\end{tabular} & B1 & B0 \\
\hline $\begin{array}{l}\text { Transitoripollis sp. cf. T. similis } \\
\text { Góczán \& Juhász, } 1984\end{array}$ & & & & 7.7 & 2.2 & 13 & & 0.8 & 0.3 & 0.7 & & & 4.4 & & & 0.7 & & & 1.2 & 1 & \\
\hline Tricolpites blechrus Ward, 1983 & & & & & & & & & 0.3 & & & 0.3 & & & & & & & & & \\
\hline $\begin{array}{l}\text { Tricolpites crassimurus (Groot \& } \\
\text { Penny) Singh, } 1971\end{array}$ & & & 0.3 & & & & & & & & 0.3 & & 7.4 & & 2.1 & 4.6 & 0.4 & & 0.60 & 0.5 & 0.2 \\
\hline $\begin{array}{l}\text { Aff. Tricolpites crassimurus (Groot \& } \\
\text { Penny) Singh, } 1971\end{array}$ & & & & & & & 6.4 & & 0.7 & 1 & & 0.4 & & & & 1.3 & & & & 0.5 & \\
\hline & & & & & & ALC & $\mathrm{AAE}$ & & & & & & & & & & & & & & \\
\hline $\begin{array}{l}\text { Pterospermella aristotelesii } \\
\text { (loannides et al.) Srivastava, } 1984\end{array}$ & 0.4 & & & & & 12.5 & & & & & 0.3 & & & & 1.1 & & & & & 0.2 & \\
\hline $\begin{array}{l}\text { Schizophacus grandis (Hedlund) } \\
\text { Pierce, } 1976\end{array}$ & & 0.7 & & & & & & & & & & & & 0.4 & & 0.7 & 0.4 & & & & 0 \\
\hline $\begin{array}{l}\text { Schizophacus parvus (Cookson \& } \\
\text { Dettmann) Pierce, } 1976 \\
\end{array}$ & & & & & & & & & 0.3 & 1 & & 0.7 & & 3.9 & 3.2 & & 0.4 & & 0.3 & & \\
\hline $\begin{array}{l}\text { Schizophacus spriggi (Cookson \& } \\
\text { Dettmann) Pierce, } 1976 \\
\end{array}$ & & & & & & & & & & & & & & 2.2 & 3.2 & 0.7 & & & & & \\
\hline $\begin{array}{l}\text { Schizosporis microreticulatus } \\
\text { Brenner, } 1963\end{array}$ & & & & & & & & & 0.3 & & & & & & & & & & & & \\
\hline $\begin{array}{l}\text { Schizosporis reticulatus Cookson \& } \\
\text { Dettmann, } 1959\end{array}$ & & 0.3 & & & & & & & 0.3 & & & & & & & & & & & & \\
\hline & & & & & & FUI & VGI & & & & & & & & & & & & & & \\
\hline Dicellaesporites sp. & & & & & & & & & 0.3 & & & & & & & & & & & & \\
\hline Plochmopeltinites sp. & & & & & & & & & & 0.3 & & & & & & & & & & & \\
\hline Pluricellaesporites sp. & & & 0.3 & & & & & & & & & & & & & & & & & & \\
\hline Polyadosporites sp. & & & 0.3 & & & & & & 0.3 & & & & & & & & & & & & \\
\hline & & & & DTHE & ER P & ALY & $\mathrm{NO}$ & $\mathrm{MOF}$ & $\mathrm{RPH}$ & & & & & & & & & & & & \\
\hline Foraminiferal linings & & 0.3 & & & & & 3.2 & 4.6 & & & $0.3 \Theta$ & & & & & & & & & & \\
\hline Cuticle 1 & 0.8 & & & & 0.3 & & & & & & & & & & & & & & & & \\
\hline Cuticle 2 & & & & & 0.3 & & & & & & & & & & & & & & & & \\
\hline Incertae sedis 1 & & & 0.3 & & & & & & & & & & & & & & & & & & \\
\hline Incertae sedis 2 & & & & & & & & 0.4 & & & & & & & & & & & & & \\
\hline Incertae sedis 3 & & & & & & & & 0.4 & & & & & & & & & & & & & \\
\hline & & & & DINOF & FLAC & GEL & LAT & TE C & YST & & & & & & & & & & & & \\
\hline Cribroperidinium sp. & & & 0.3 & & & & & & & & & & & & & & & & & & 0.1 \\
\hline $\begin{array}{l}\text { Cyclonephelium chabaca Below, } \\
1981\end{array}$ & & 3 & 12 & 0.32 & 21.3 & & & 54.2 & 1 & 4 & & & & & 1.1 & & & & 0.6 & & 0.1 \\
\hline Florentinia spp. & & & 0.3 & 0.3 & 0.3 & & 3.2 & 0.4 & & & 0.3 & & & & & & & & & & \\
\hline $\begin{array}{l}\text { Oligosphaeridium pulcherrimum } \\
\text { (Deflandre \& Cookson) Davey \& } \\
\text { Williams, } 1966\end{array}$ & & & 0.3 & & 0.3 & & & 6.1 & 0.3 & & 0.7 & 0.4 & & & & & & & & & \\
\hline Subtilisphaera sp. & & & 0.3 & & & & & & & & & & & & & & & & & & 0.1 \\
\hline Inderminate dinoflagellate cysts & & 45 & & & & & & & 0.7 & 2 & 2.1 & 2.2 & 5.9 & 1.7 & 5.3 & 5.3 & & & & 2.4 & \\
\hline
\end{tabular}


APPENDIX. - Continuation.

\begin{tabular}{|c|c|c|c|c|c|c|c|c|c|c|c|}
\hline & & & & S & & & & $\mathbf{F}$ & & PL & HU \\
\hline & 6 & \begin{tabular}{l|l}
7 & $\varepsilon$
\end{tabular} & \begin{tabular}{l|l}
3 & 9
\end{tabular} & 10 & \begin{tabular}{l|l}
11 & 12 \\
2
\end{tabular} & \begin{tabular}{l|l}
2 & 13 \\
\end{tabular} & 1 & 2 & 4 & 0 & \begin{tabular}{|l|l|l|l|l|l|l|l|} 
I & II & III & B9 & B3 & B2 & B1 & B0 \\
\end{tabular} \\
\hline
\end{tabular}

\begin{tabular}{|l|c|c|c|c|c|c|c|c|c|c|c|c|c|c|c|c|c|c|c|c|c|}
\hline $\begin{array}{l}\text { Total Palynomorphs (excluding } \\
\text { dinoflagellate cysts) }\end{array}$ & 243 & 156 & 333 & 296 & 251 & 8 & 30 & 104 & 288 & 286 & 281 & 261 & 63 & 228 & 88 & 144 & 267 & 26 & 276 & 403 & 1515 \\
\hline $\begin{array}{l}\text { Total Palynomorphs (including } \\
\text { dinoflagellate cysts) }\end{array}$ & 243 & 301 & 383 & 298 & 321 & 8 & 31 & 264 & 294 & 304 & 290 & 268 & 69 & 232 & 94 & 152 & 267 & 30 & 326 & 413 & 1520 \\
\hline Bryophyta/Total (\%) & 0.4 & & 1.3 & 0.3 & 0.6 & & & & 1 & 1.3 & 0.3 & 0.4 & & & & & & & & & \\
\hline Pteridophyta/Total (\%) & 19.7 & 11 & 42.3 & 21 & 29.9 & 38 & 52 & 8.7 & 34.7 & 35.2 & 32.4 & 23.9 & 13 & 2.2 & & 1.3 & 1.1 & & 0.3 & & 0.3 \\
\hline Gymnosperms/Total (\%) & 67 & 27 & 31.6 & 60 & 41.4 & 13 & 23 & 23 & 22.4 & 45.7 & 40 & 21.6 & 29 & 10.3 & 11.7 & 17.8 & 1.9 & 23.4 & 1.2 & 1 & 0.2 \\
\hline Angiosperms/Total (\%) & 11.5 & 13 & 10.7 & 18 & 5.6 & 38 & 19 & 2.3 & 38.4 & 10.2 & 23.8 & 50.8 & 52.2 & 76.3 & 68.1 & 74.3 & 96.2 & 63.3 & 82.8 & 96.4 & 99.1 \\
\hline Algae/Total (\%) & 0.4 & 1 & & & & 13 & & & 1 & 1 & 0.3 & 0.7 & & 6.5 & 7.4 & 1.3 & 0.7 & & 0.3 & 0.2 & 0.1 \\
\hline Fungi/Total (\%) & & & 0.5 & & & & & & 0.7 & 0.3 & & & & & & & & & & & \\
\hline Other Palynomorphs/Total (\%) & 0.8 & 0.3 & 0.3 & & 0.6 & & 3.2 & 5.3 & & & $\mathbb{8}$ & & & & & & & & & & \\
\hline Dinoflagellate cysts/Total (\%) & & 48 & 13 & 0.7 & 21.8 & & 3.2 & 61 & 2 & 5.9 & 3.1 & 2.6 & 5.8 & 1.7 & 6.4 & 5.3 & & 13.3 & 15.3 & 2.4 & 0.1 \\
\hline
\end{tabular}

